\title{
LAND USE DEVELOPMENT AT INTERSTATE INTERCHANGES IN INDIANA
}

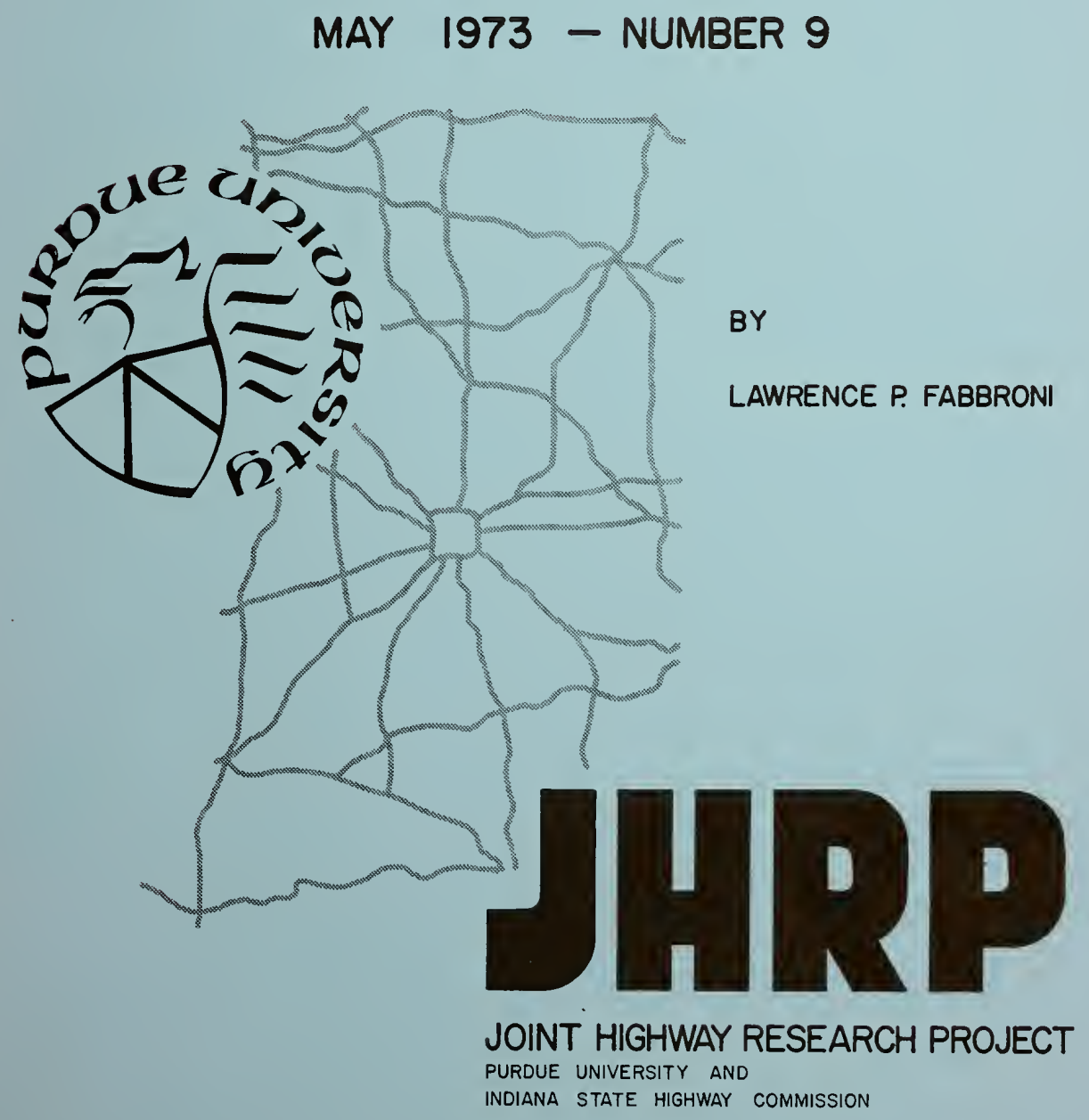


Final Report

LAND USE DEVELOPMENT AT INTERSTATE INTERCHANGES IN INDIANA

TO:

J. F. McLaughlin, Director

Joint Highway Research Project

FROM: H. L. Michael, Associate Director Joint Highway Research Project
May 3, 1973

File: $\quad 3-8-4$

Project: $\quad C-36-70 D$

The attached Final Report has been prepared by Mr. Lawrence P. Fabbroni, graduate Assistant in Research on our staff, under the direction of Professor G. T. Satterly, Jr. The Report is titled "Land Use Development at Interstate Interchanges in Indiana" and was also used by Mr. Fabbroni as his thesis for the MSCE degree.

The purpose of the study was to determine the extent of land use development, land use change and land use control at Interstate interchanges. Much land use development primarily road user services types, was found at many interchanges. Land use control was found to be virtually nonexistant. One of the major benefits of the research is demonstration of how realistic application of land use planning and controls at interchanges could be developed to the advantage of road users, developers and the community.

The Report is presented for acceptance as fulfillment of the objectives of the Study.

Respectfully submitted,

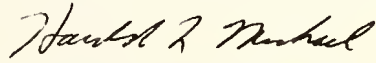

Harold L. Michael

Associate Director

IILM : ms

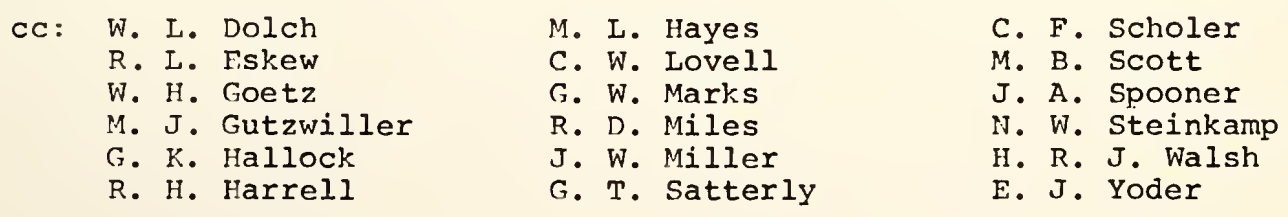


Digitized by the Internet Archive in 2011 with funding from

LYRASIS members and Sloan Foundation; Indiana Department of Transportation 
Final Report

LAND USE DEVELOPMENT AT INTERSTATE INTERCHANGES IN INDIANA

\author{
by \\ Lawrence P. Fabbroni \\ Graduate Assistant in Research
}

Joint Highway Research Project

File: $\quad 3-8-4$

Project: $\quad C-36-70 D$

Conducted by

Joint Highway Research Project Engineering Experiment Station

Purdue University

In Cooperation with

Indiana state Highway Commission

Purdue University West Lafayette, Indiana May 3, 1973 


\section{ACKNOWLEDGMENTS}

The author extenus his gratitude to the Directors of the Joint Highway Research Project for enabling him to attend Purdue for Graduate Study.

INo amount of thanks can suffice in recognizing the encouragement and motivation my family has provided me during this research effort.

The esteem of the author goes to Dr. Gilbert T. Satterly of the School of Civil Rngineering for his major review and constructive comments throughout the study; to Professor Robert D. Miles for his help and his guidance; to Dr. Villiam Grecco for his substantial input; to Professor Harold 2 . Michael for his review and his encouragement; and to Dr. W. J. Studden, Department of Mathematics and Statistics for his review.

Ir. Howard of ISHC, Mr. Campoly of ISHC, Mr. Cox of DOT, Mr. Blyart of ISHC, Mr. Barker of ISHC, and Mr. Henderson of the Department of Commerce are but a few whose help was most needed and appreciated.

Final thanks are extended to all Traffic Iab Graduate Students, particularly, A. Hobeika, W. IicGuirk, T. Butcher, D. Ripple, and M. Hernan; to my typist, Miss Jane Pierce; and to all the Traffic Lab Draftsmen. 
TABLE OT CONTENTS

PAGE

LIST OF TABLES . . . . . . . . . . . . . . . . vi vi

LIST OF FIGURES . . . . . . . . . . . . . . . . . v vii

ABSTRACT . . . . . . . . . . . . . ... ... ix

CHAPTER I - INTPODUCTION . . . . . . ........... I

Scope ........................ 2

Gozls ........................ 3

Objective ...................... . 3

Need For Study ... . . . . . . . . . . . . 3

CHAPTER II - PAST RFSEARCH IN THES ARRA • • • • • • • • • 4

CHAPTIPR III - CONCEPTUAL BASIS . . . . . . . . . . 7

Delimitation .................. . . 7

1 Conceptual Approach To The Model Hypothesized . . . . . 7

CHAPTIR IV - DATA COLLECTION . . . . . . . . . . . 13

Data Inventory .. . . . . . . . . . . . . . I3

Data Manipulation . . . . . . . . . . . . . 26

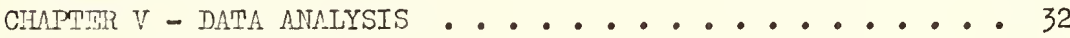

Variable Develoment . . . . . . . . . . . 32

Dependent or Response Variable . . . . . . . . 32

Independent Variable ... . . . . . . . . . . . 33

Assumptions For The Statistical Hethod .......... 35

Statistical Measures . . . . . . . . . . . . 36

CHAPTER VI - INTHRCHANTGE CAST STUDIES. . . . . . . . . 41

Case I: Interchange of Interstate 65 and State Route 46 . 43

Case II: Interchange of Interstate 65 and U.S. Route 50 . . 45

Case III: Interchange of Interstate 74 and U.S. Poute 231. - 47

Case IV: Interchange of Interstate 74 and State Route 44 - 49

Case V: Interchange of Interstate 69 and State Route 8 • 51

Case VI: Interchange of Interstate 71 and State Route 3 . . 53

Case VII: Interchange of Interstate 65 and Statc Route 30. - 56

CaseVIII: Interchance of Interstate 69 and State Route 3 . 58

Case IX: Interchange of Interstate 70 and U.S. Route 4I . . 60

Case X: Interchange of Interstate 65 and U.S. Route 131 - 62 
Jllustrated Interchange Mrea Planning ....... 67

Policc Porers. ............. 67

Thinent Jomain............... 68

Special Interchance Area District. . . . . . 69

CIAPTER VII - SUIILPY AND CONCLUSIONS ......... 78

Road User Services ........... . . 78

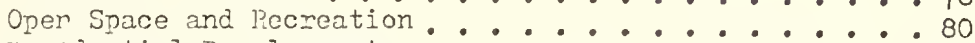

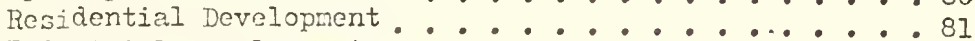

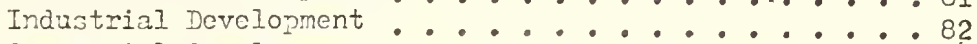

Comnercial Complexes .............. 82

CHAPTIR VIII - RECONTERDATTONS FOR FURTHER RESEARCH . . . . 85

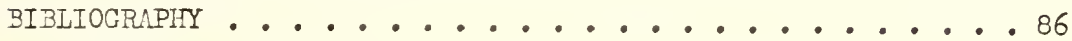

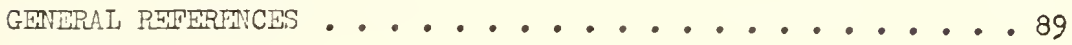
APPENDICES

Appendix $\Lambda$ : Definitions........... 92

Units of Development ........ 93

Appendix B: Inventory Forms and questionnaires ... .95

Appendix C: Inventory Coding Procedures...... . 98

Appendix D: ADT Expansion Factors....... 12J.

Appendix I: Statistical Plots For The Land Use. .

Development Model.................. 


\section{IIST OF TABLES}

TABILE

PAGE

I Quadrants with Development by liumber and Location 30

2 Travel Distance to Travel Time Conversion Factors 31

3 Iand Use Weights 32

4 Model I Results 38

5 Model 2 Results 39

6 Final Model Results 40

7 Suburban Interchaneses Cumulative Land Use Development 65

8 Urban Fringe Interchanges Cumulative Land Use Development 66 


\section{LIST OF FIGURES}

FIGURE

PAGT

I Interchange Area System Logic Diagrams

2 Intcrchance Area System Loric Diagrams Continued

3 OveralI System Diagram

4 Interchange Arca Development Symbol Code

5 Interstate 69 Interchange Development

6 Interstate 69 Interchange Development Continued

7 Interstate 74 Interchange Development West of Indianapolis

8 Interstate 70 Interchange Development West of Indianapolis

9 Interstate 70 Interchance Development Bast of Incianapolis

10 Interstate 74 Interchange Devolopment Fast of Indianapolis

II Interstate 65 Interchange Development South of Indianapolis

12 Interstate 65 Interchange DeveIopment North of Indianapolis

13 Interstate Interchance Development by Type of Interchange and by percentase of Land Ise Type

14 Interstate Interchange Development by Type of Interchange and by Percentage of Land Use Type

I5 State Route 46 and Interstate 65 Interchange

I6 U.S. Route 50 and Interstatc 65 Interchance 
FIGURE

18 State Route 44 and Interstate 74 Interchange

19 State Route 8 and Interstate 69 Interchanoe

20 State Route 3 and Interstate 74 East Interchange

21 U.S. Route 30 and Intcrstate 65 Interchange

22 State Route 3 and Interstate 69 Interchance

23 U.S. Route $4 I$ and Interstate 70 Interchange

$24 \quad U_{S}$. Route 131 and Interstate 65 Interchange

25 Zoning in Interchange Area Planning

26 Official lapping and Subdivision in Interchange Area Planning

27 Setback Requirements and Driveway Permits in

Interchange Area Planning

28 Design Controls in Interchange Area Planning

29 Estimated Daily Trip Generation Chart for Bxisting I-69 and SR 8 Development

30 An Interchange Area Plan Alternative for I-69 and SR 8

31 Estimated Daily Trip Goneration Chart for Planned I-69 and $S R 8$ Developrnent

APPENDIX

FIGURE

BI Data Sheet for Field Survey

D1 Volume Adjustment Factors

D2 Volume Adjustment Factors

El Histogram of Weighted Development 22 Cases

E2 Residual Histogram for Final Weighted Model with 52 Cases 
ABSTRACT

Fabbroni, Lawrence Peter. Ir.S.C.E., Purdue University, December 1972. Iand Use Development at Interstate Interchanses in Indiana. Major Professor: Dr. Gilbert T. Satterly.

The purpose of this research project was to determine the extent of land use development, land use chanse, and land use control at Interstate interchanges open to traffic for more than two years. Results of the inventories and the agrregate land use development macnitude model should enable highway planners to pinpoint existing areas requirino immediate comprehensive interchange land use planning and to refer to typical development trends in planning for new interchanges alone limited access roadways.

Data was gathered from secondary sources available at the ISHC, the Indianapolis IOT, and the Indiana Department of Comerce Bureau of Planning, and from in-field interviewing and surveys.

Road user services were found to constitute the bulk of early post interchange opening development. Residential, commercial, and industrial land uses, while increasing in area coverage as the nearby urban center sizes increase, occurred before, during, or after Interstate opening depending on the extent of urban growth out to the Interstate and interchanges when first opened. Iand use control was found to be virtually non-existent; but, the portions of the interchange area which werc planned and controlled were accumulated in a land use control listing whose realistic application is demonstrated in a sample of how an existing interchance area might be developed for the benefit of road users, developers, and planners if planning through a land use control packaç is effectively implemented early. 
CHAPTER I

INTRODUCTION

The United States has planned, designed, financed and constructed a significantly improved and comprehensive transportation network since 1956. Many of the improvements will connect formerly scattered and sometimes isolated transportation routes. 42,500 Interstate miles designed and built to freeway standards will be part of the final comprehensive transportation system.

Since "transportation improvement shifts the comparative advantages of places," (6) existing cities are growing and major economic activities simultaneously shifting toward the new freeways. Therefore, freeway design characteristics, most notably limited access and grade separation, have created new magnets for land uses, especially those uses necessary to travelers, at the selectively placed freeway interchanges.

Highway planners and designers have realized for over a decade that "interchanges can serve as an instrument to open up new areas for sound economic growth, to revive the economic vigor of places that need economic revival and perhaps to be the nucleus for a new kind of community." (25)

This study has determined what land use growth has occurred at Indiana freeway interchanges since their opening and what land use, design, or traffic controls have been implemented in planning interchange areas. 
This is a study of interchange area develonment for Indiana interchanges open more than two years before Tanuary 1972. The intcrchanges included in the survey are as follows:

Interstate Route 65 Interchanges from the State Route 334 Interchange northwest to the State Route 52 Interchange.

Interstate Route 65 Interchanges from the US 24 . Interchange north to the US 30 Interchange.

Interstate Route 69 Interchances from the State Route 9 Interchange north to the US27 Interchange near the Michigan border.

Interstate Route 65 Interchanges from the US 31 Interchange south to the State Route 131 Interchange.

Intcrstate Route 70 Interchanges from the Post Road Interchange cast to the US 40 Interchange.

Interstate Route 70 Interchanges from the State Route 267 Interchange west to the US 40 Interchange.

Interstate Route 74 Interchanges from the Post Road Interchange east to the US 52 Interchange.

Interstate Route 74 Interchanges from the State Route 267 Interchange west to the State Route 53 Interchange.

All other interchanges in Indiana were excluded from consideration for reasons of interchange age, of extensive traffic redistribution in the area as occurred on I-465 South when I-165 North opened, of existing saturated urban development, or of unique route location, route operation, or route interconnection. Development for a mile along the crossroute on both sides of the Interstate interchange was considered as being the interchange area. 
This study has determined the change in land use at Indiana Interstate interchanges since their opening and has suggested controls for interchange area land use development.

\section{Objectives}

Land use development trends and land use magnitudes were quantitatively summarized by aggregate summaries and by selected case studies. Land use, design, and traffic controls were inventoried and compared through case studies for effectiveness.

\section{Need For Study}

If we continue the dangerous pattern of piece by piece development in our new and future interchange areas, the end product will surely be blighted, unattractive strip development with excessive access points, with insufficient building setbacks, inadequate parking and unloading areas, and excessive traffic generation. The aftermath of urban bypasses should be enough evidence that unplanned crossroutes interchanging with our new freeways can follow a similar strip development course. "The danger is very real that the facilities serving Interstate system interchanges will become functionally obsolete through development of land uses that generate traffic exceeding their design capacities." (20)

This research fills a gap for Indiana by presenting actual land use development conditions at Interstate interchanges with a general methodology for controlling future development. 
CHAPTER II

PAST RESEARCH IN THIS AREA

In 1961 a Highway Research Board Symposium (13) on Interstate interchange development and land use control stimulated states' interests in helping localitic develop interchance area plans. Subsequently, many states including Indiana (9) issued interchange area planning brochures briefly explaining the importance of interchange planning by local planning commissions or groups and how to utilize state aid of funds or of manpower to act on early policy making for interchanges. There was some follow-up by local Indiana jurisdictions with a study on planning orderly Iake County Interstate interchange area growth (14) as an example.

To plan for orderly growth all such studies must ideally make a sound prediction of the amount and type of interchange land use development. Adequate prediction of development along the crossroute in the interchange area would provide a partial measure of interchange benefits while forevaming of needed land use controls to maintain efficient development in the future.

In several states the first predictive step after delimiting the interchange area, and establishing goals and objectives for their development study, has been a complete inventory of existing development at all interchanges. A study at the University of Tennessee (22) determined the property tracts, property sales, and property use at 74 interchanges along I-40 between Memphis and Knoxville in Tennessee. Similarily, Barton-Aschman Associates, Inc. surveyed Illinois Interstate interchanges throughout the state and subsequently selected critical areas for further case study.

The continuum from general survey to specific studies has progressed to different extents in many states. Most notably, Pennsylvania State University, after completing a Manual for Interchange Area Planning has carried on continuous case study work on physical, social, and economic impacts of Interstate interchanges at the Institute for Research on Land and Water Resources. Fyerly has studied the formation of new properties, changes in real estate values, changes in land use and reasons for change 
at selected interchanges (4). Saulender and others (21) studied economic impact of selected interchanges. Dansereau and his associates (3) looked at social aspects, such as education, occupation, and socioeconomic status of interchange communities.

Utah developed an instructional manual from a detailed survey of thirteen randomly selected interchange areas (26). The Ohio State Highway Department (18) and the Wisconsin State Highway Department (23) have each done impact studies on selected Interstate interchanges. A Michigan study considered interchanges along I-94 to determine development success by by interchange quadrant, by interchange type, and by interchange location (2).

Thile working for state or for federal agencies, several individuals have become interested in studying interchange area development factors. Kuhn of the University of Wisconsin, while looking at the entire planning problem of predicting probable development, of estimating resultant generation by development type, and of devising suitable legal controls, has concentrated his detailed work primarily on trip generation by type of establishment. His detailed road user interviewing at sixteen interchanges indicated preference for interchanges and particular land uses according to factors, such as, quadrant location, site availability, interchange type, major oil. company brand availatility, and user familiarity with the area (12). Theil (25), while stressing economic control planning aspects, compiled an extensive list of factors leading to Interstate interchange development. This list adds population of the interchange area, traffic on the feeder crossroad, age of the interchange, freeway capacity, and land area available for development to Kuhn's factors mentioned above. Garrison structured his view of interchange area development as being a system whereby individuals, private firms, and govemment agencies locate with a comon economic efficiency objective (5).

All these studies by states and individuals have collected data on many interchanges concerning development. As a prime objective or often as a byproduct of inventory research, suggested explanatory variables for interchange development have evolved. However, presently no known researcher has collected sufficient data to model interchange land development based on factors believed to cause such growth. Mason inAlabama (16) hopes to use annual photographs of Alabama Interstate 
interchanges, taken each of the past seven years, to explain the type and rate of development at interchances by using 1970 Census information as social, economic, and demographic independent variables in a multiple regression model. Kuhn is also reaching the point where his data bank will allow altemative models of customer generation by type to be tested. 


\section{CHAPTFR III \\ CONCEPTUAL BASIS}

\section{Delimitation}

This study was concerned with the development around Interstate interchange areas. A survey of other reports and handbooks on interchange studies conducted in other states establishes a common range of areas from within a one-half mile radius to within a mile radius of each interchange. After preliminary inspection of land use development through aerial photographs and through general field inspection this Indiana interchange study considered only that development for one mile on both sides of the Interstate interchange and visible from the crossroute.

The interchange population is composed of all interchanges not judged to be extensively developed before interchange construction as with a right of way through an existing urban community, not in an area of highly unstable travel patterms and of land development as with the circunferential route at Indianapolis, and not with unique peculiarities by virtue of route location or of interchange type, as with I-64 interchanges or with freeway to freeway interchanges respectively.

\section{Concentual Anoroach To The Model Hypothesized}

The interchange area boundary was considered to be the boundary for the interchange area system. A change in that system's state can occur when an activity, communication, or channel crosses the boundary and enters the system (input), when an activity, communication, or channel experiences change within the system (intra), or when an activity, communication, or channel crosses the system boundary and leaves the system (output).

The state or response variable modeled is the marnitude of road usex type development within the interchange system. The inputinduced change in development is principally caused by movement of an 
establishment into the interchange area system. The intra-induced change comes about through expansion of existing devclopment, consolidation, or temporary closing of establishments. The output would come with increased advantage in other developing locations over time making abandonment of the present prime interchange area system economically desirable.

The independent factors in the model are also hypothesized according to the input, intra, and output system interactions defined above. With a discrete magnitude describing the state of a system, the system interactions described by independent factors are quantified at a corresponding level of detail for inclusion in the model. For instance, Average Annual DailyTraffic is used as a measure for channel usage outside, across, or within the interchange system boundaries rather than refinement to seasonal or hourly absolute volumes.

With the system, state of the system, and level of agregation all introduced, the spectrum of causal factors producing a change of state are hypothesized to come from three main categories, the road user, the business developer or manager, and interchange characteristics.

Crossroute volume is indicative of road user activity within the capacity constraints of the channel across and within the system boundaries. Crossroute volume can be input, intra, or output in producing change in the magnitude of development of the interchange system. As input to the system, crossroute volume represents a consumer market whose needs can be potentially satisfied by road user services within the interchange area system. In addition to a roadway to parking exchange at the driveways, a crossroute to Interchange exchange can be initiated at the ramp terminals within the interchange area system. The third altermative for crossroute volume is the road user traveling through the interchange area without an inner system destination. off ramp volumes are hypothesized to indicate a potential for road user input to the interchange area system as a forced input created by lack of services on the Interstate facility. Although a mathematical component of the crossroute volume, the ramp volume, 
constituting a distinctive captive market for road user establishments, is treatcd as a separate and independent factor.

of the factors considered by business owners in establishinf an onterprise within the interchance area system, the economic climate of a location is the major criteria. This climate includes changes in the environment extermal to the interchange area system. For instance, cities alon: the crossroute but outside of the interchange area are expanding and while growth has been shown to be reflected in the increased crossroute volume, the nearness and the size of the urban growth are hypothesized as causes of differing magmitudes of road user development in nearby interchange systems. Because, as population growth promotes economic growth, this economic growth may or may not occur within the interchange area system depending on urban area neamess and size. So accessibility measured by time from interchange to urban center and attractiveness measured by population or change in population appear to be valid independent factors to be tried separately or in combination in modeling road user development magnitudes.

While accessibility and attractiveness can account for interchange arca market potential and market shift from old parallel routes, the neighboring interchance area system's magnitudes of development and nearmess can not be ignored as measures of competition.

Finaliy, the characteristics of the interchange area system itself should bc considered as possible factors affecting the state of the system from within (intra). These factors are interchange design type, age of interchange, age of Interstate, and the nature of the interchange location as either agricultural, suburban, or urban.

The interchange area as a system whose road user developments can be modeled by aggregate measures of road user patronage, of economic business desirability, and of interchangc attributes constitutes this report's conceptual basis for analysis. This research is exploratory for Indiana in establishing development and proper controls for interchange areas with the look toward better implementation of interchange area planning, design, and operation in the future. 


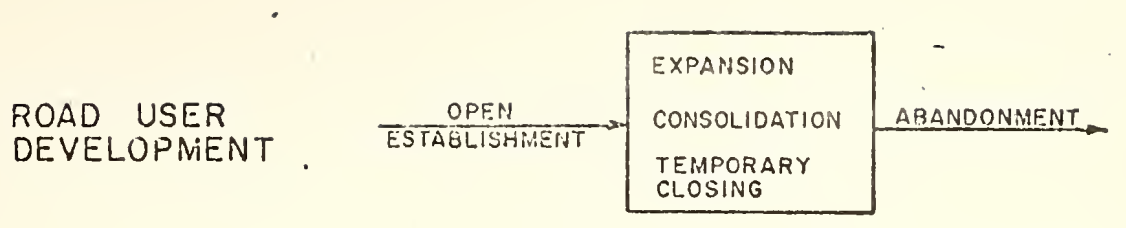

CROSSROUTE VOLUME

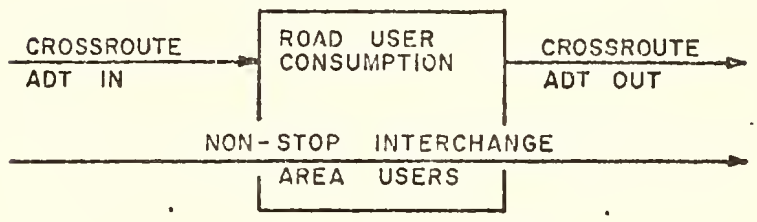

RAMP

VOLUME
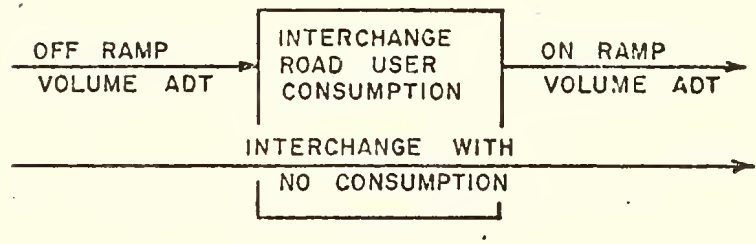

ECONOMIC CLIMATE

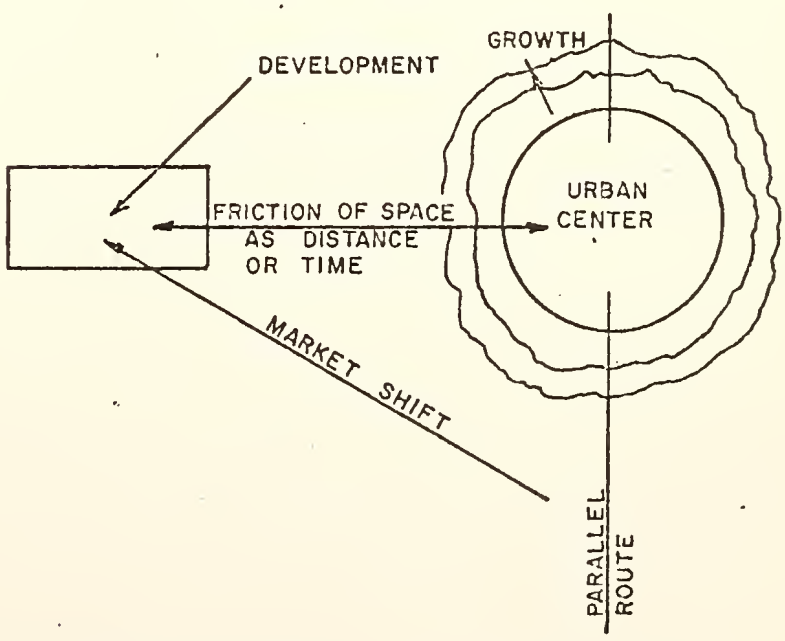

FIGURE I. INTERCHANGE AREA SYSTEM LOGIC DIAGRAM 
COMPETITION

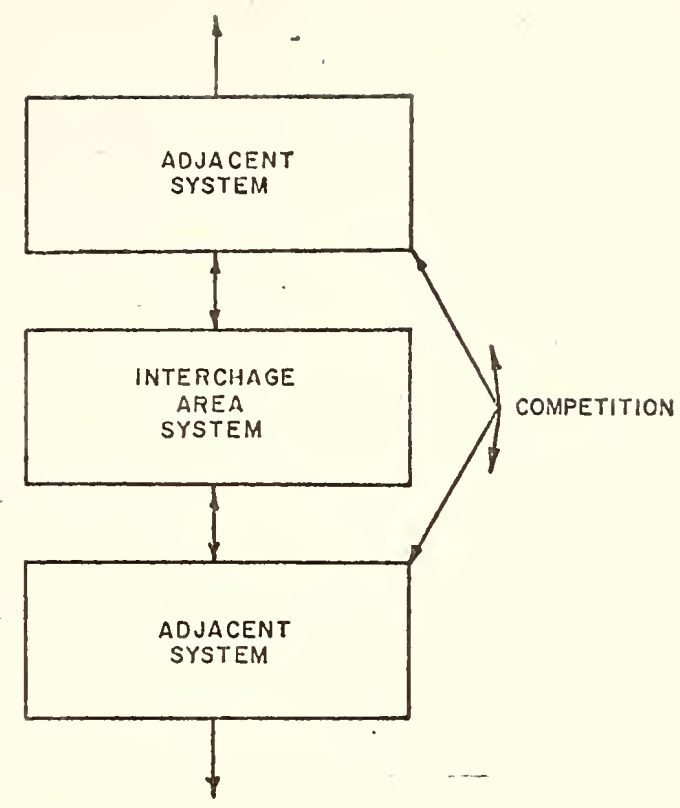

INTERCHANGE CHARACTERISTICS

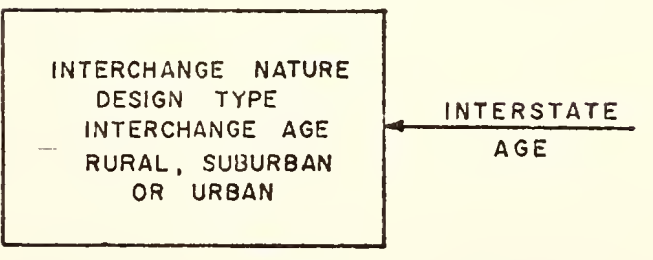

FIGURE 2. INTERCHANGE AREA SYSTEM LOGIC DIAGRAMS CONTINUED 


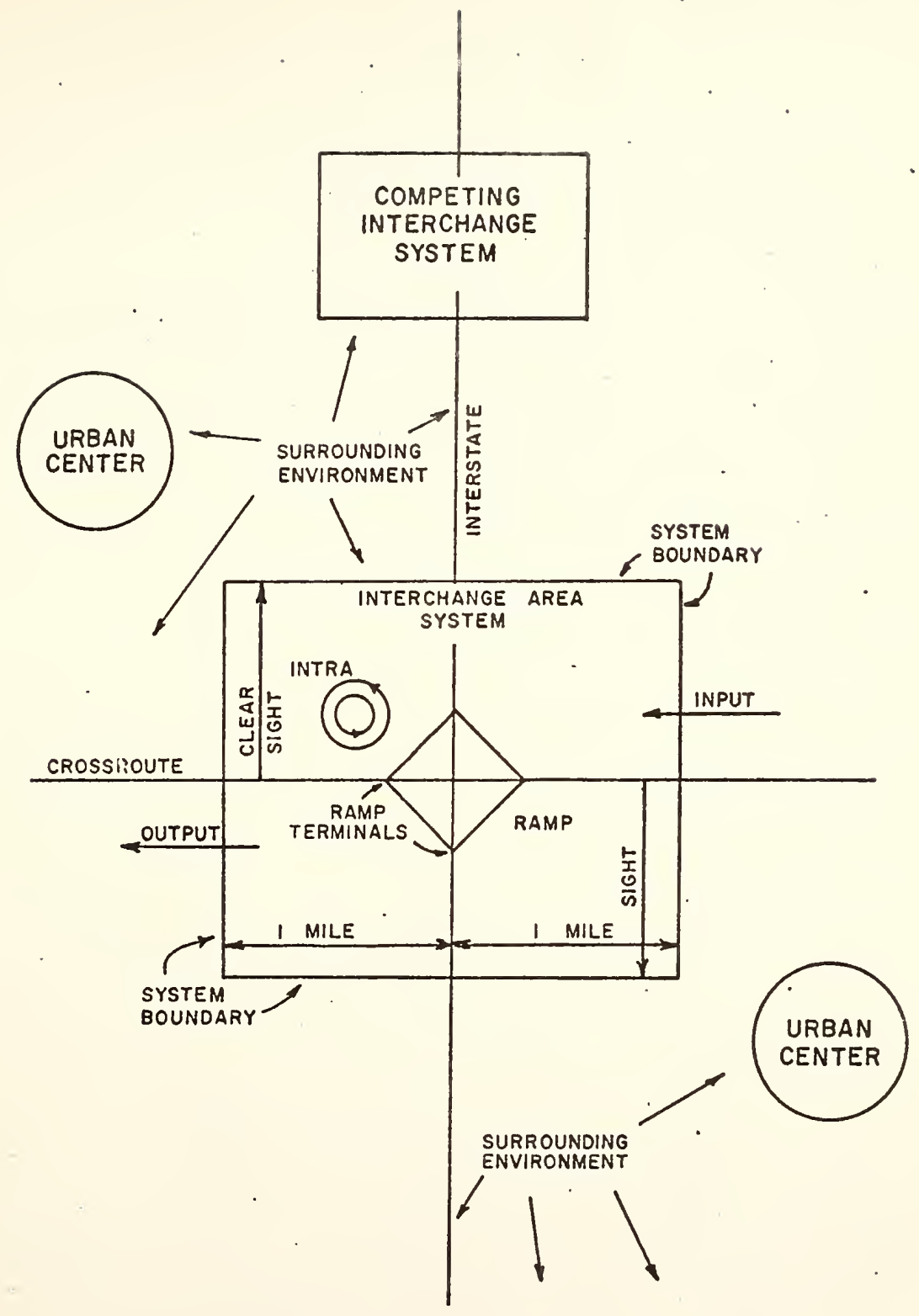

FIGURE 3. OVERALL SYSTEM DIAGRAM 
CHAPTER IV

DATA COLLECTION

\section{Data Inventory}

A random sample was chosen from the 102 interchange population by randomly ordering each interchange and subsequently randomly numbering the random order. The total sample of interchanges was thirty-three or approximately thirty percent of the interchange population. This sampling procedure was used to chose those interchanges which as a subpopulation were felt to be representative of the entire interchange population.

The aerial photography for different periods of development of the sampled interchange areas was studied through the cooperation of the Photolab of the Aerial Photography Department of the Indiana State Highway Commission in Indianapolis. The photomraphy is flown periodically for the United States Geological Survey and on a special project basis for the Indiana State Highway Commission.

$\Lambda$ fter inspection of photographic sequences for seven interchanges of the random sample as flown periodically since 1956, a few shortcomings of using aerial photography became apparent. Since the entire state is not photographed in any one year there is a problem in quantitatively studying growth from data for different interchanges at staggered time intervals. For instance, if a Before and After Study on interchange area road user establishment growth were undertaken, there is insufficient photography for the interchange areas sampled to study a given time before and a given time after each interchange opening. Similarily, if development trends were to be studied dynamically over time, photography at eoual intervals after opening for all sampled interchanges is unavailable. Advance planning similar to that for an ongoing Alabama study (16) to shoot annual photography of interchanges after oponing is necessary to render aerial photography useful for time series studies. Additionally, in sparser developed areas 
parcel identification by boundary lines of the area bought, as contrasted with the area utilized by investors is very difficult, if not impossible, to identify. Area of owmership and area of utilization are both important background to anticipate the extent of development possible in an interchange area with as yet undeveloped tracts and to anticipate further development by owners already opcrating road user services. An example of expansion which must be anticipated is an oil company which opens a gas station primarily for automobile service, follows with a restaurant addition, and eventually expands to handle trucks or there is a motel with an initial sixty-unit building investment but with adequate additional site area to add sixty units and also build a night club and two office towers.

Although abandoned, the preliminary photographic work with the seven interchanges mentioned above was the basis for an emphasis shift to studying road user development at all 102 interchanges of the interchange population, rather than a random sample.

Since establishment opening dates and land area of road user establishments were needed to describe trends and extent of development, driveway permits for any establishment desiring direct access to a State Highway crossroute within the interchange area were next sought. All such permits should be centrally housed in the Indiana State Highway Commission files.

Each permit specifies information on the proposed development's area and often is accompanied by a sketch showing the location of proposed structures or improvements, such as, drainage fields, water wells, gasoline pumps, areas for parking, buildings, light and advertisement towers, driveways, and necessary culverts. The better plans show driveway and lot line proximity to the Interstate right of vay, to the Interstate center line, and to the closest Interstate ramp terminal. However, the dates on the permits and the permit records of land development often differ greatly with actual field development dates and field development respectively. Actual opening field dates were found to lag the date of permit review by one year. Also, as an example of the inadequate permit correlation with actual development, of the permits located on file for all establishments at the Interstate 
interchanges between Anderson and the Michigan State line along I-69, roughly half are not built. Furthermore, half of those found in a field study of that stretch on I-69 were not on file in the state office. This deternination made it clear that the permits could not be used as a sole source of data and that a comprehensive field survey was necessary.

The field survey was conducted during January 1972 by one interviever. The purposes of the survey were to inventory development in the interchange area systems as of January 1972, to determine the sequence of development up until that time, and to get a field impression of the interchange or crossroute performance problems, if any, that existing or anticipated developnent might cause, now or in the near future. These objectives vere met by utilizing a three source survey consisting of a sketch map, an intervier, and a mail-in questionnaire (Appendix B). A Sketch map of establishments and approximate position with respect to the Interstate ramps for each interchance was done by a windshield survey with the aid of an odometer. An interview was conducted to determine the first opening date of the establishment. When the person interviewed could not answer the question conceming original opening, the simple questionnaire with cover letter was left to be completed and returmed by mail. Of fifteen questionnaires distributed ten were returmed. An accuracy check on unsure field reaponses by questioning adjacent owmers or managers concerning a neighbor's founding date corresponded within six months in most cases. There refusal to answer or an inability to answer or to contact someone who could answer was encountered, the permit date adjusted by an average year building lag was used. A total of 370 interviews were conducted in this phase of the study.

Figures 4 through 12 show the results of the field survey by units of land use types as defined in Appendix A. As may be noted in that Appendix, non-road user land uses, such as, residential and industrial land uses are very crudely estimated. 


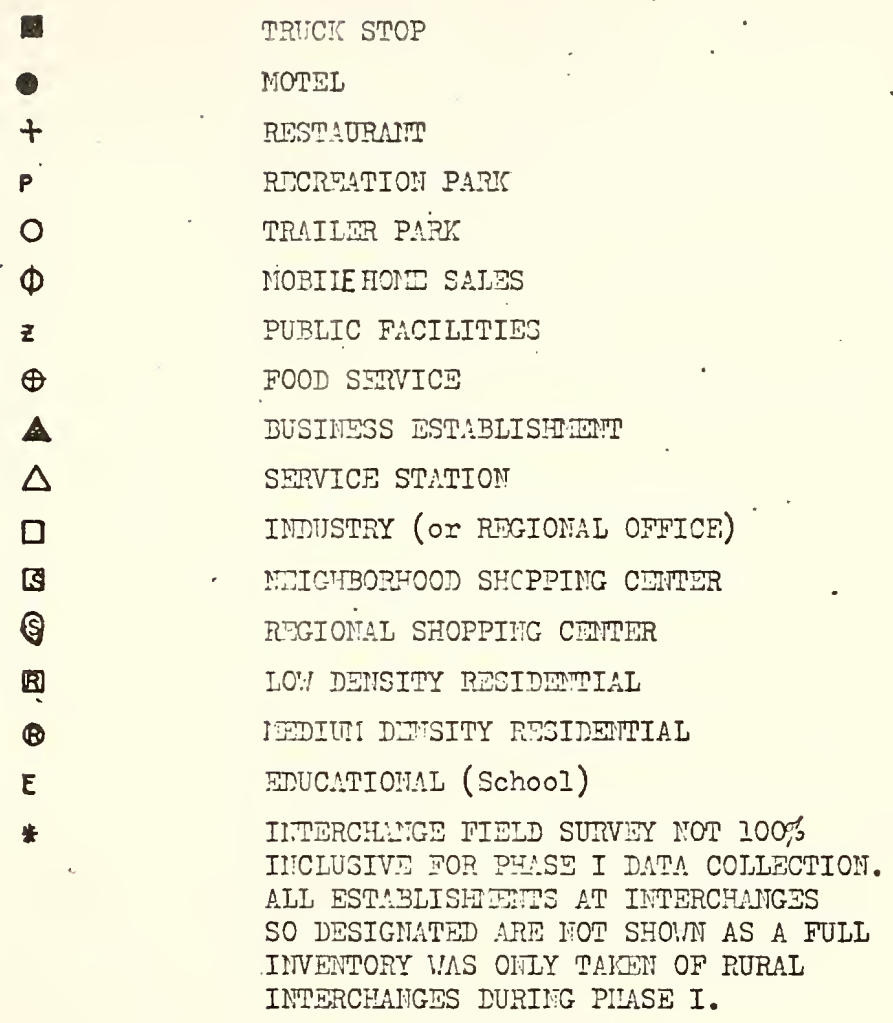

FIGURE 4. IINTERCHANGE AREA DEVELOPIIFNT SYTBOL CODE 


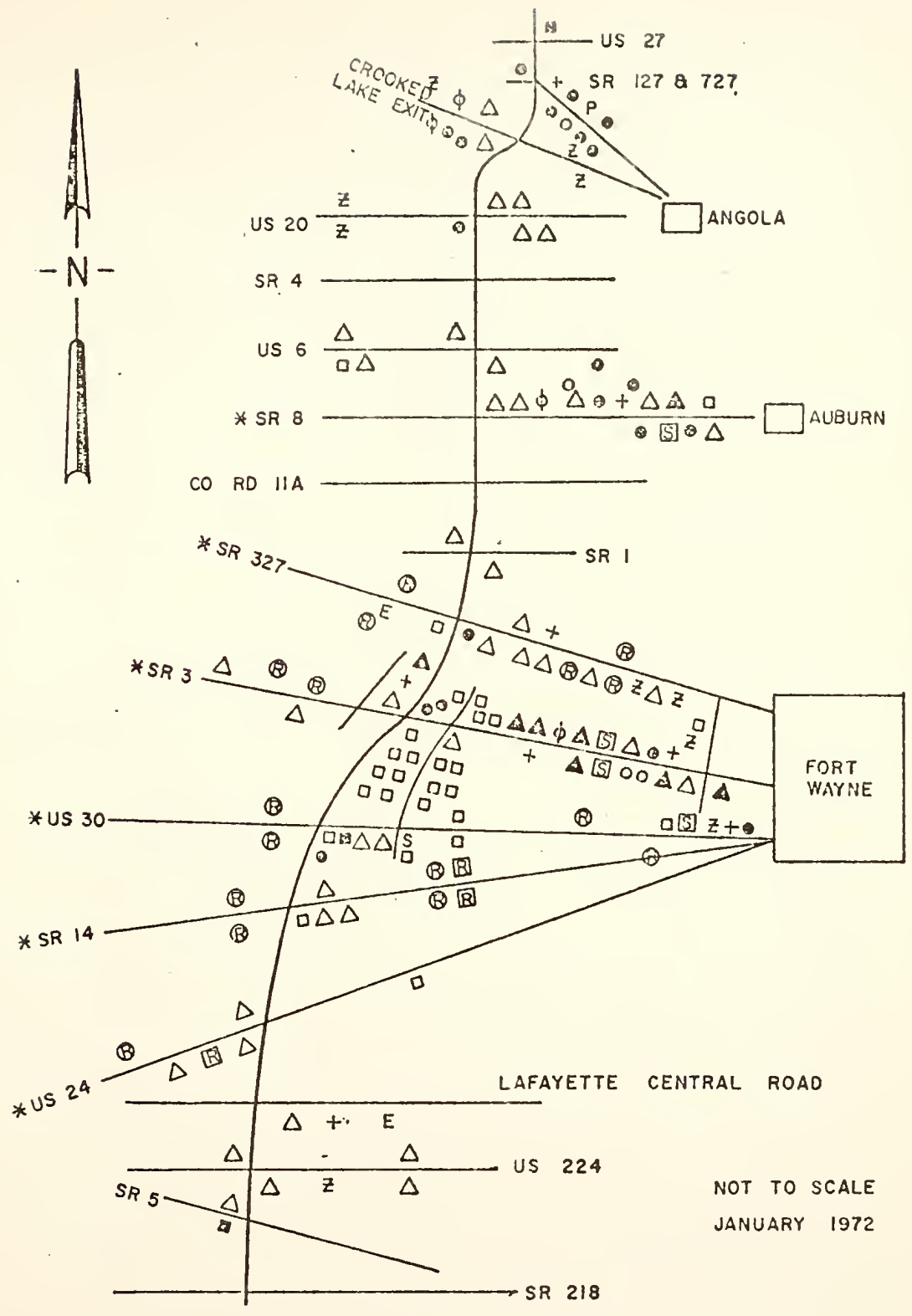

FIGURE 5. INTERSTATE 69 INTERCHANGE DEVELOPMENT 


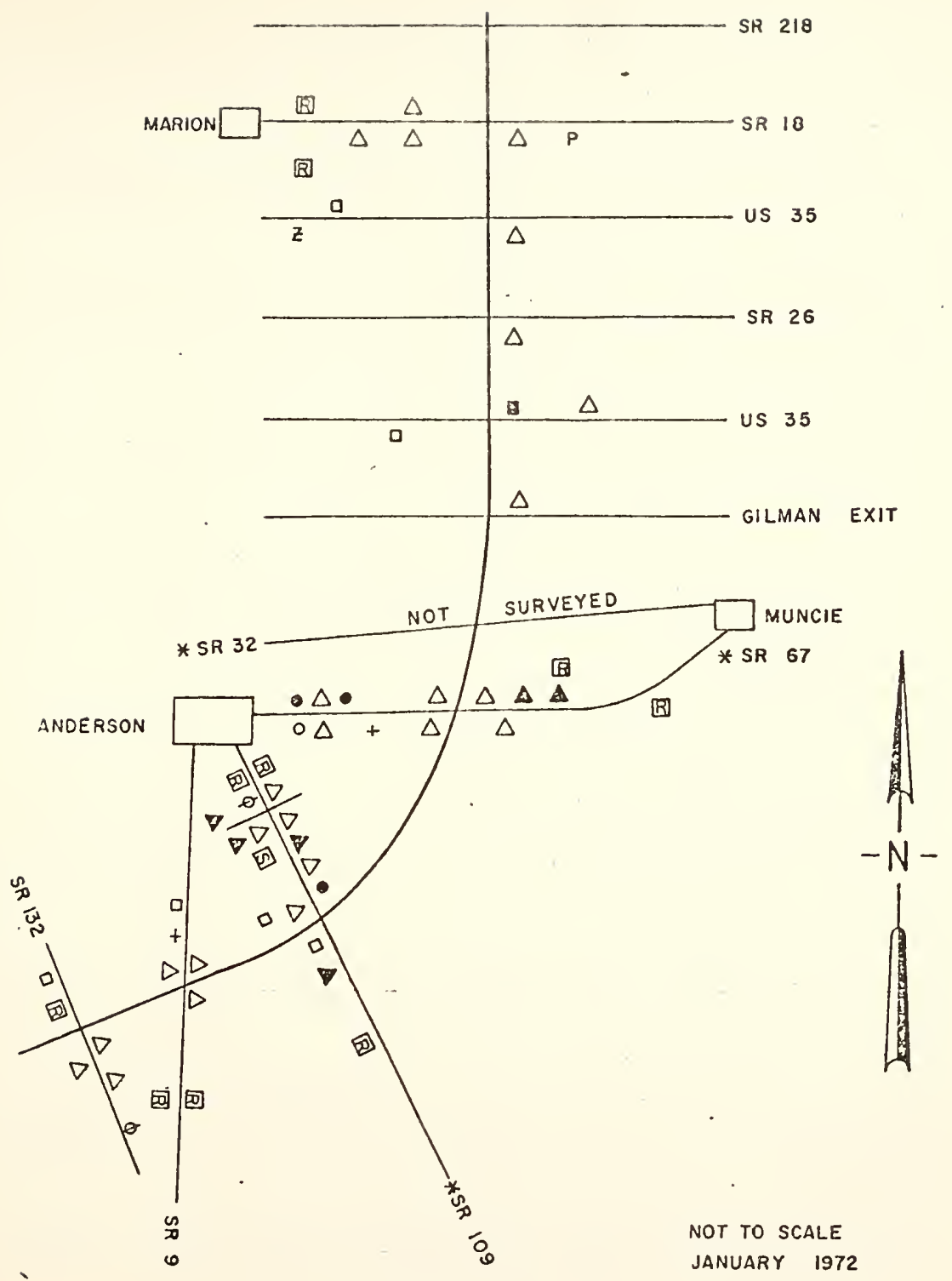

FIGURE 6. INTERSTATE 69 INTERCHANGE DEVELOPMENT CONTINUED 


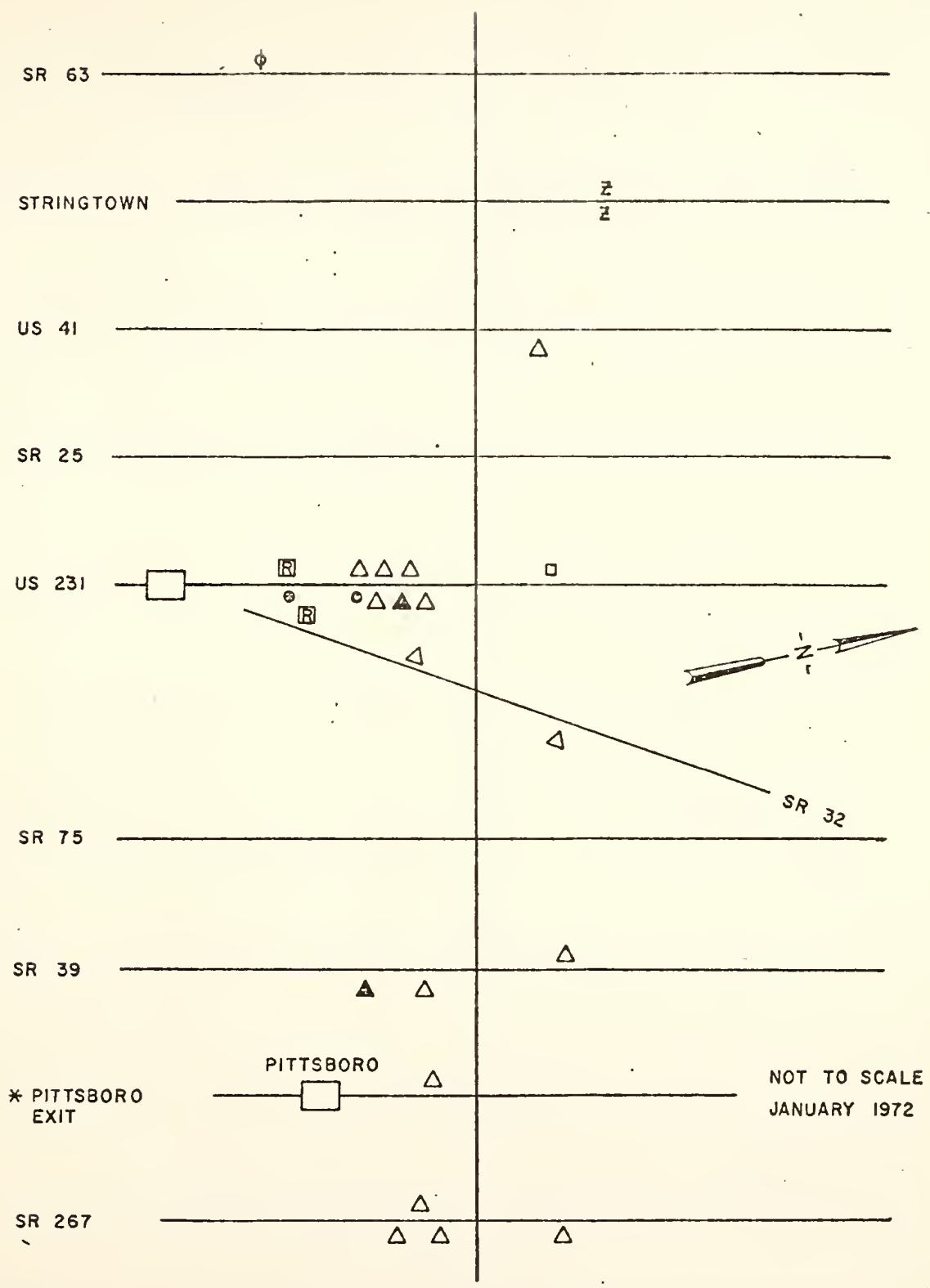

FIGURE 7. INTERSTATE 74 INTERCHANGE DEVELOPMENT WEST OF INDIANAPOLIS 


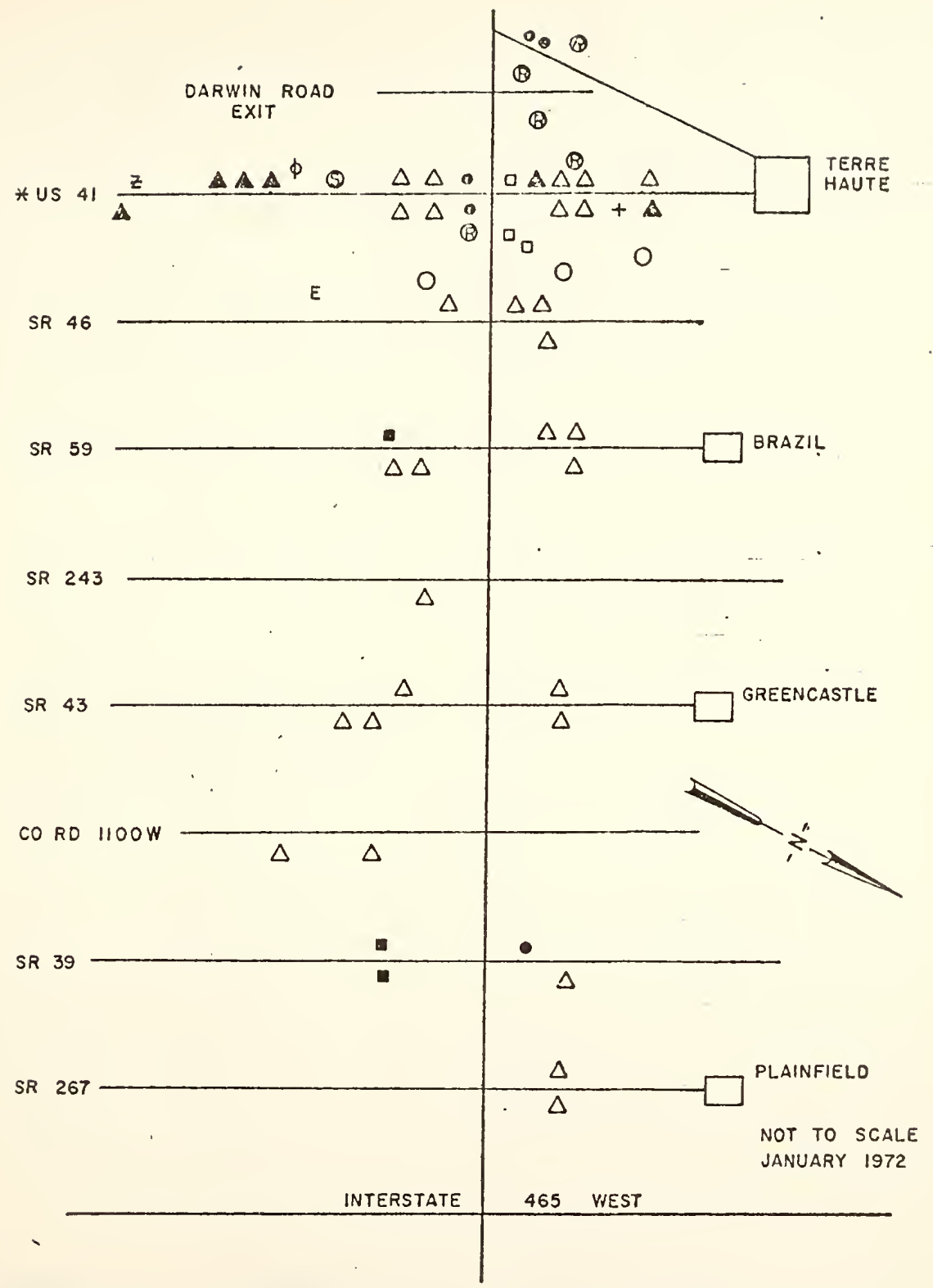

FIGURE 8. INTERSTATE 70 INTERCHANGE DEVELOPMENT WEST OF INDIANAPOLIS 


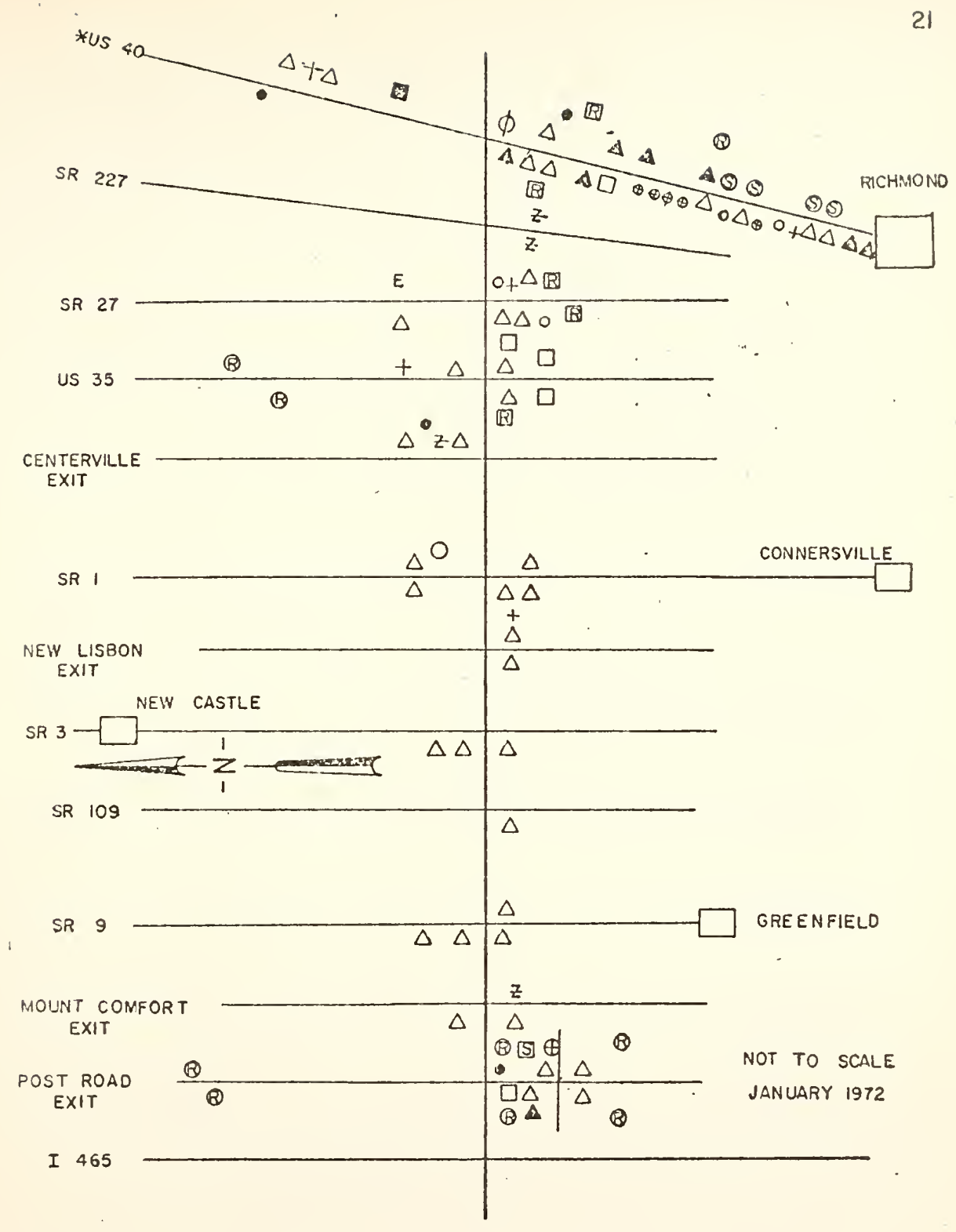

FIGURE 9. INTERSTATE 70 INTERCHANGE DEVELOPMENT EAST OF INDIANAPOLIS 


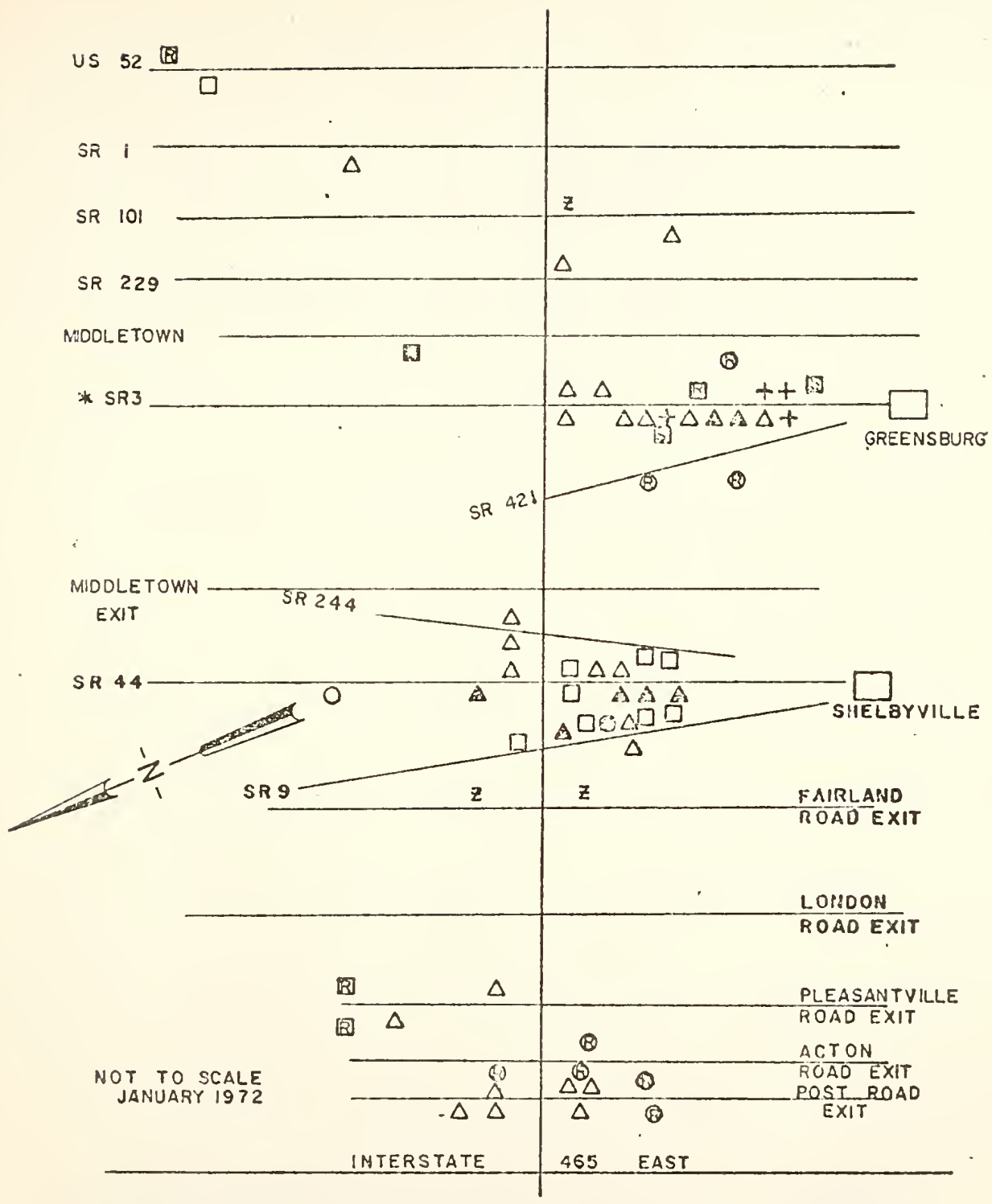

FIGURE 10. INTERSTATE 74. INTERCHANGE DEVELOPMENT EAST OF INDIANAPOLIS 


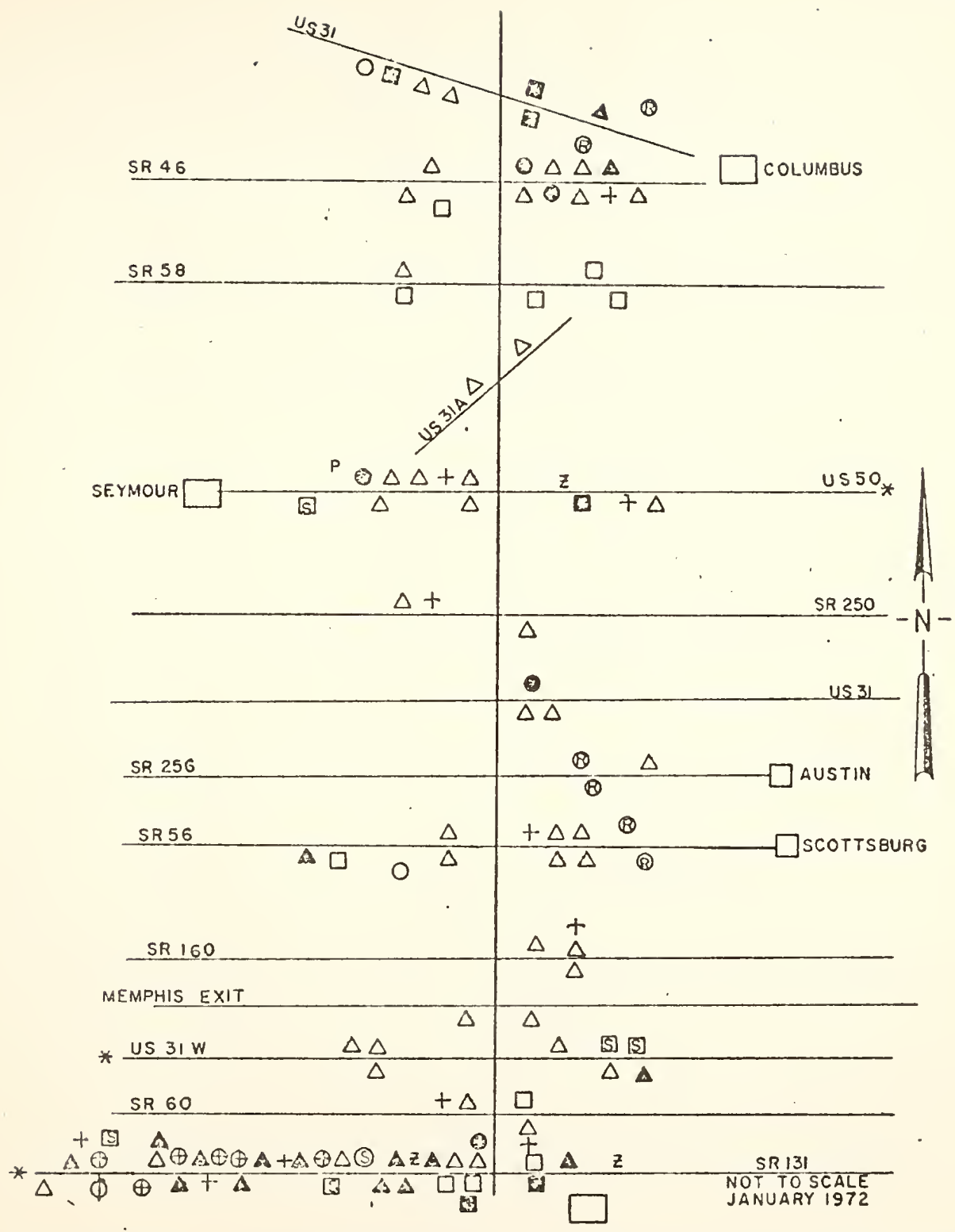

FIGURE II. ' INTERSTATE 65 INTERCHANGE DEVELOPMENT SOUTH OF INDIANAPOLIS 


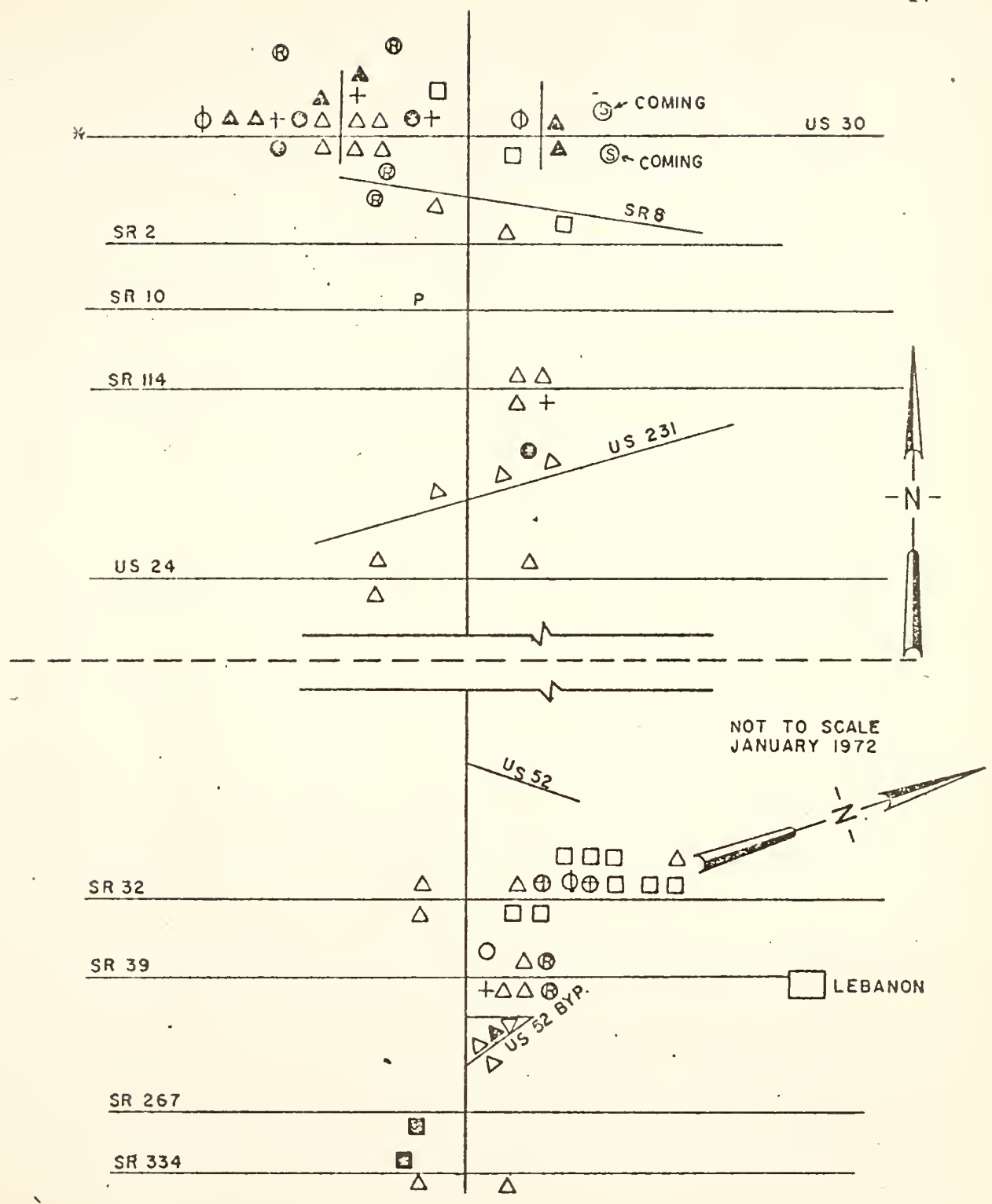

FIGURE 12. INTERSTATE 65 INTERCHANGE DEVELOPMENT NORTH OF INDIANAPOLIS 
Volumes on the crossroute, ramps, and Interstate were all collected from volume maps or field sheets available from the Traffic Planning Division of the Indiana State Highway Commission. Where complete volumes for a given interchange were not found on the statewide 1952, 1958, 1962, 1966, and 1969 volume maps, supplemental strip maps, isolated counts, or interchange volume maps were utilized; and, state conversion factors to adjust to approximate ADTs were used as listed in Appendix $D$.

Populations of urban areas over 1000 were obtained from 1950, 1960, and 1970 Census Reports of Indiana.

Travel distances were taken as measured or as recorded from the 1971-1972. Indiana State Highway System road map (Scale; l"=5miles). Distances were measured from interchange to interchange, interchange to urban centers, and interchange to old parallel State highway routes. The data manipulation section will describe the conversion of travel distances to travel times.

Interchange type was established from ISHC desion drawings and checked during the field survey.

Interchange and Interstate roadway section ages were taken from maintenance records establishing maintenance responsibilities for new Interstate roadway sections. This source provided the best estimate of the interchange opening dates since no complete tabulation of opening dates or of construction dates were available in the Construction Division of the Indiana State Hishway Commission.

Accident tabulations on the statewide Accident Spot Maps were considered unreliable for meaningful aggregate traffic hazard evaluation. Accidents were also too difficult to obtain in detail from the Indiana State Highway Patrol files or from original accident records throughout the state within the reasonable scope of this project and so unfortunately were excluded from the study. 
Data Manioulation

Before any data analysis was undertaken, the raw data as collected was punched onto computer cards. The coding system shown in Appendix C was desicned for the short term purposes of this research as well as for more diverse demands of future research.

Each of the variables required some data summarization and data transformations prior to modeling. Summarizations and transformations of the development were used to determine homogeneous classes of data, to approximate similar levels of ageregation for all variables, and to approximate a comnon base measure for each variable.

Figures 13 and If show percentages of existing land development by land use type on a one establishment one unit of development measure criteria.

For all 102 intcrchanges studied, road user services, including gasoline stations, truck stops, motels, and restaurants, represent 58.2 percent of existing establishments. This percentage increases to $76.9 \%$ for mural interchanges, is $58.7 \%$ for suburban interchange area systems, and decreases to $46.5 \%$ for urban fringe interchanges. Private commercial and shoppine centers constitute $11.7 \%$ of development for all interchanges, $1.7 \%$ in the rural areas, in $12.3 \%$ in the suburban areas, and $19.2 \%$ in the urban fringe areas; industrial $11.1 \%$ in ali areas, $5.7 \%$ in rural areas, $12.2 \%$ in suburban areas, and $12.6 \%$ in urban fringe areas; and as a last major development category combined residential is found as a land use in $10.5 \%$ of all interchange areas, $8.0 \%$ of mural interchange areas, $11.6 \%$ of suburban interchange areas, and $11.6 \%$ of urban fringe interchange areas. These comparisons reflect the interdependence of Iand uses and the importance of complimentary market areas. For instance, the noticeable increase in private commercial establishments with increased urban influence reflects the importance of a superimposed total of Interstate travelers, crossroute travelers, and local convenience travelers in interchange location decisions of private enterprise.

A classification of rural, suburban, and urban fringe interchanges by geometric interchange design type resulted in the tabulation of establishments as shown in sumnary Table 1. 

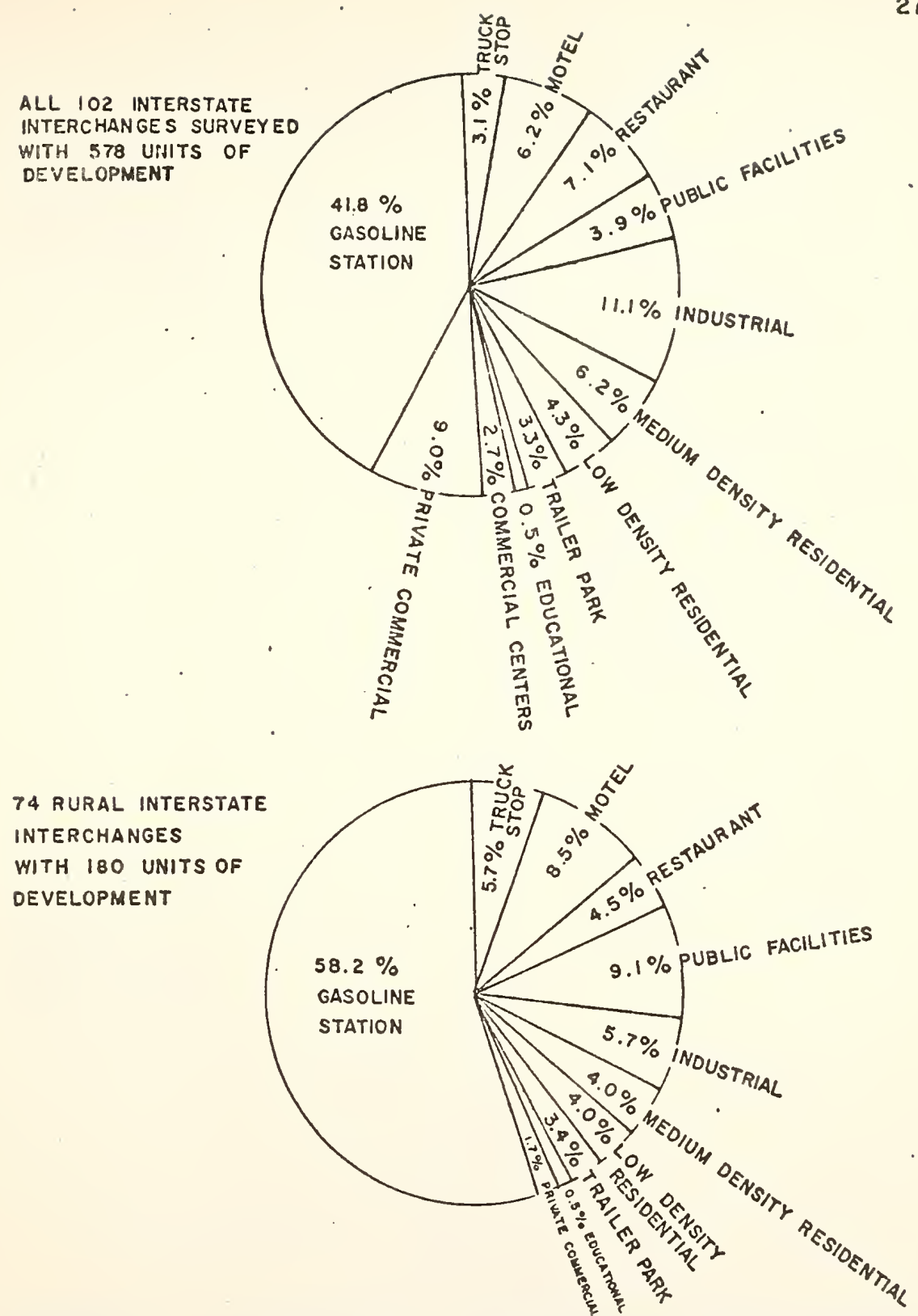

FIGURE 13. INTERSTATE INTERCHANGE DEVELOPMENT BY TYPE OF INTERCHANGE AND BY PERCENTAGE OF. LAND USE TYPE 
21 SUBURBAN INTERSTATE

INTERCHANGES

WITH 222 UNITS

OF DEVELOPMENT

7 URBAN FRINGE INTERSTATE INTERCHANGES WITH 176 UNITS OF DEVELOPMENT

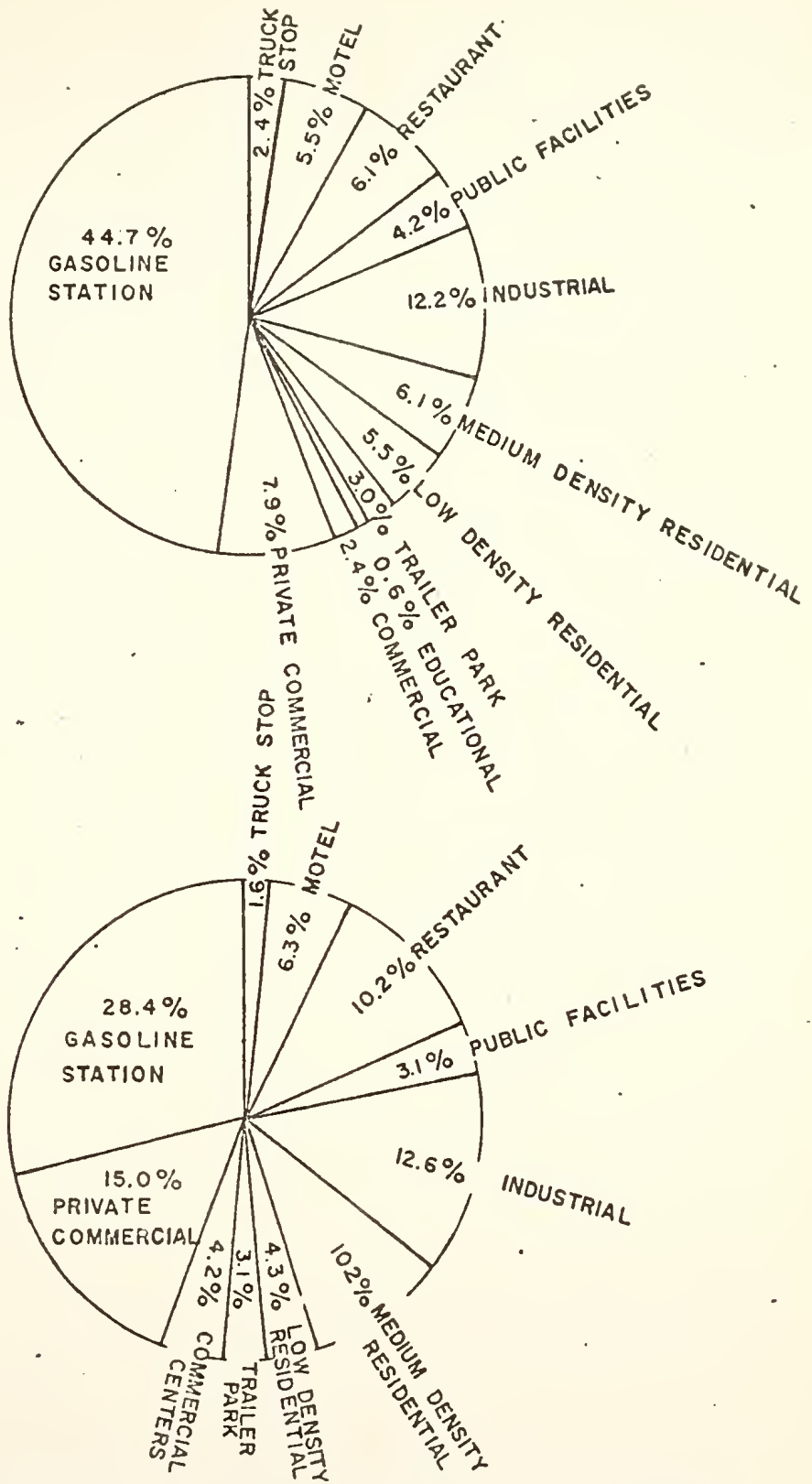

FIGURE 14. INTERSTATE INTERCHANGE DEVELOPMENT BY TYPE OF INTERCHANGE AND BY PERCENTAGE OF. LAND USE TYPE 
These breakdowns in Ficures 13 and 14 and Table 1 were useful to 29 determine that diamond interchanees of the mural type constitute the only homotenous class with enourch road user land use obscrvations to warrant upcoming modeling consideration.

While not within the scope of this research, it was felt that similar percentage summaries based on future expansive multi-state inventories would be very useful in establishing probabilities for parcel by parcel estimation of future land uses after being initially categorized by factors such as interchange characteristics and interchange design type.

As may be noted several volume counts were collected over time for crossroutes, ramps, and Interstate routes. There were several reasons for this. First, the time series data enabled us to make a fair estimate of 1971 volumes where they were not counted or not available for 1971. In projecting volumes, if only one count was available for crossroute, ramp, or Interstate link, the 1971 volume was estimated as a four percent (17) increase in volume per year from the time of the single count. Where two counts were available a straight line projection to 1971 was used. For three or more counts over time, the rates of change between successive counts were determined, were averaged, and this average rate when multiplied by the time lapse in years since the most recent count would yield the absolute change in that count resulting in an acceptable estimate of 1971 volume of the lïnk in question. Secondly, time series data makes short term predictive applications of the model possible by making projection of these potential independent variables very easy. But, far better than this projection of a deterministic model; future research, after a good model is built for 1971, could formulate models with identical variables for, as an example, three year intervals prior to 1971 to do a pseudo-dynamic analysis of change in parameters and to identify a mathematical expression of causal relationships over time.

of the raw data collected the other major transformation prior to modeling was in converting minimum travel paths from distances to times. The minimum travel path in time was determined manually in distances broken down by freeway, foun lane rural, two lane rural, and 


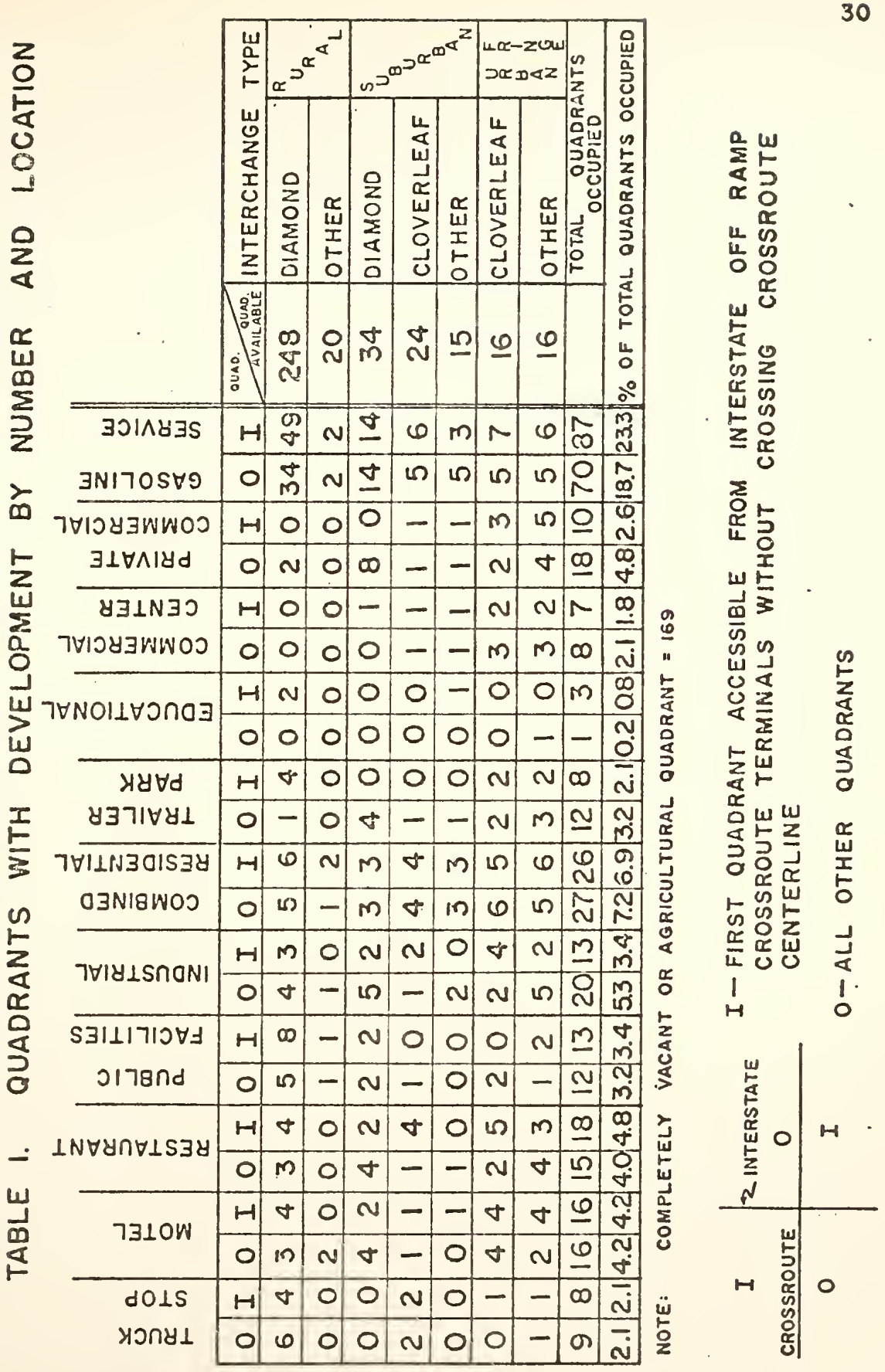


four lane urban mileages. These distances were converted to minimum time by using the average speed of travel considered representative (27) for the differing roadways and corresponding conversion factors as Iisted in Table 2.

TABIE 2

TRAVEL DISTANCE TO TRAVEL

TIME CONVERSION FACTORS

INTERSTATE

SPSED

CONVEESION FACTOR

4-IANE RURAL

6OMPH

1.00

2-IANE RURAL

5OMPH

1.20

4-IANE URBAN

45MPH

1.33

उONTH

2.00 


\section{CHAPTER V \\ $\therefore$ data analysis \\ Variable Development}

Dependent or Resnonse Variable

The response variable modeled is the magnitude of road user developments at an interchange. Tho altemative models were developed. One model considers each road user establishment as one unit of development. For instance, an interchange with two gasoline service stations and another interchange with two truck stops would each rate as two units of development.

In the other model a weight was applied to each development in recognition of the fact that each land use activity generates varying amounts of traveler conflicts at crossroute access points. The following subjective weights consider these different anticipated eneration rates by land use type but do not reflect finer bases of sophistication which would result from an extensive traffic count by land use type study.

TABLE 3

LAND USE THIGHTS

$\begin{array}{ll}\text { WEIGHT } & \text { LAND USE (See Appendix C) } \\ 1 & \text { Sorvice Station } \\ 2 & \text { Service Station + Restaurant } \\ 1 \frac{1}{2} & \text { Iotel (Large Chain) } \\ \frac{1}{2} & \text { Motel (Small Chain) } \\ 1 & \text { Restaurant } \\ 4 & \text { Truck Stop (Auto-Food-Lodgin-Truck Service) } \\ 3 & \text { Neichborhood Shoppinc Center } \\ 6 & \text { RerionaI Shopping Center } \\ 1 \frac{1}{2} & \text { Service Station + Short Order }\end{array}$


Crossroute volume, rnmp volume, Interntate volume, interchance are, and Interstate age verc all used in the fom resulting from initial data manipulation as described in the preceeding chapter.

A population index was developed from the ponulations and minimum travel time from the interchange to the population centers. The premise is that an index composed of the summation of population divided by the accessibility within a given corridor of travel. For example, interchange $I$ in corridor $\Lambda$ would have a population index $I_{I}=\sum_{i=1}^{n}\left(\frac{\text { pon } i}{(\operatorname{dist} I-i}\right)^{m}$ where $I_{I}$ is the index, $\mathrm{n}$ is the number of population centers with population greater than 1000 in corridor $A$, pop $i$ is the population of center $i$ in corridor $\Lambda$, and (dist $1-i)^{m}$ is the distance in minimum travel time from interchanse population center $i$ raised to an exponent $\mathrm{m}$ to be calibratcd. The corridors for the different Interstate routes radiating away from Indianepolis extend twenty miles at the most to either side of the Interstate. Where two Interstates' comidors would overlap, as is the case when nearing Indianapolis, the area between Interstate routes was bisected to establish a breakpoint for one corridor from another. For example, US 52 was roughly the boundary for the corridors of I-70 and I-74 just East of Indianapolis until Rushville where the twenty mile limit takes effect.

The exponent in was calibrated by plotting population indexes based on distance exponent values of $\mathrm{m}=1.0,1.1,1.2,1.3,1.4,1.5,1.6,1.7,1.8$ $1.9,2: 0,2.3,2.6,2 \cdot 9,3.2,3.5,3.8,4.1,4.7,5.0$ in the denominator used once each with $10 \% 10$ pop $i$, square root pop $i$, and pop $i$ in the numerator for each interchange versus the weighted development at that interchange. The plots showed no distinct linear or curvilinear relationships although the graph with 10 g $10 \mathrm{pop} i /(\text { dist } 1-i)^{l}$ seemed to be the Eraph with least disparity from a linear plot and so $I_{I}=\sum_{i=1}^{n}$ log 10 pop $i /(\text { dist } 1-i)^{l}$ was the population index used for each interchange.

$\Lambda$ variable labeled conomic shift index was also developed. The data used to develop this index was based on volumes on routcs parallel to the Interstate, bisectine the crossroute, and within the Interstate comidor as delimited for the population indexes above. For 
each interchange, volumes on both sides of the crossroute were collected and averaged for each parallel route. The average parallel volumes recorded before interchange opening were then projected to 1969 for each parallel route. This volume projection was estimated by using average rates of volume change or a $4 \%$ increase where only one jrear's volume record was available, much as the crossroute, ramp, and Interstate volumes were projected earlier. The parallel route projection was then compared to the actual count available on the ISHC 1969 statewide volume count map. The difference once determined was divided by the parallel route's distance from the interchange. The net result for each interchange was an Fconomic Shift Index $=\sum_{i=1}^{n}$ Diverted Volume $i /$ Distance to Parallel Route $i$, where $n=$ number of parallel routes for a given interchange.

Asgregate base variables were also developed. Populations within ten, within twenty, and within thirty minutes of each interchange were compiled as three separate potential independent variables. However since within ten minute population was a component of within twenty minute population, and both within ten minute population and within twenty minute population were components of within thirty minute population, only one of the three variables would be allowed to enter the final model because of their hich correlation with one another.

The last base variables considered were labeled weighted competition and unveichted competition. The weighted competition is simply the sum of weighted development for interchanges withir fifteen miles of the interchange syster being considered. Fifteen miles was chosen because it was subjectively decided that a person would use an intercharse for road service within thixty miles of the time he establishes his need. The unweighted competition variable was based on unveighted development totals for interchanges within fifteen miles of the interchange system being considered. The weighted and unweighted development variables were used only with the weichted and unweighted response variable models respectively and not intermixed to avoid misleading results. 
A sumarization of the base variables used for modeling and described above is as follows:

Dependent Through 1971 Weighted Development

$\begin{array}{ll}\text { Independent } & 1971 \text { Crossroute Volume } \\ \text { Independent } & 1971 \text { Off Ramp Volume } \\ \text { Independent } & 1971 \text { Interstate Volume } \\ \text { Independent } & 1970 \text { Population Index } \\ \text { Independent } & 1970 \text { Population Vithin } 10 \text { Miles } \\ \text { Independent } & 1970 \text { Population Within } 20 \text { Miles } \\ \text { Independent } & 1970 \text { Weighted Development Competition } \\ \text { Independent } & 1970 \text { Population Vithin } 30 \text { Miles } \\ \text { Independent } & \text { Interchange Age } \\ \text { Independent } & \text { Interstate Route Age } \\ \text { Dependent } & \text { Unweighted Development } \\ \text { Independent } & \text { Unweighted Development Competition } \\ \text { Independent } & \text { Economic Shift Index }\end{array}$

Assumntions For The Statistical Method

Nultiple linear regression was the method of analysis used to analyze land development in interchange areas. Some assumptions for multiple linear regression are that the independent variables are additive and uncorrelated with each other while being highly correlated in a linear fashion with the dependent variable, that there is homogeneity of variance of the dependent variable for different additive effects of independent variables, that the distribution of the error term is normal with mean zero, and that the independent variables are easily collected, easily forecasted, and causally related to the dependent variable.

Plots of each independent variable versus the dependent weighted variable were the basis for assuming a linear relationship. Because of the scattering of many of these plots, transformations and interactions of the basic variables were considered in analysis. Plotting and crossclassification and not a formal statictical test were used as a determination of homogeneity since a crossclassification of the dependent 
variable versus an independent variable contains an inordinate amount 36 of cmpty cells which it was felt would distort the value of a structured statistical test. The independent variables used in the best model are easily collected with appropriate manpower, are forecastable, and are all reasonably hypothesized through a conceptual basis of being causally related to the dependent weighted variable. Causality, put simply, means an independent variable change produces a change in the dependent variable without an intermediate variable in the chain. Normality was still assumed in spite of the discouraging plot in Appendix E.

\section{Statistical Measures}

In modeling these variables discussed earlier, the BMD2R (24) package prograrn was used for multiple stepwise regression analysis. An excellent discussion of statistical measures used in multiple stepwise regression can be found in Chapter Four of Joint Highway Research Project Number 37 (10). However, to summarize and supplement that work the statistical terms used frequently in the model result tables will now be described.

BMD2R will yield an initial correlation cofficient matrix of each variable entered to every other variable entered. While the correlation between the response variable and each independent variable is most important, the correlations between independent variables are also of interest in avoidine, where possible, collinearity of the independent variables. The initial correlation matrix is computed between each variable by using the equation

$$
r_{X Y}=\sum_{i=1}^{n}\left(x_{i}-\bar{X}\right)\left(y_{i}-\bar{P}\right) /\left(\left(\sum_{i=1}^{n}\left(x_{i}-\bar{X}\right)^{2}\right)^{1 / 2} *\left(\sum_{i=1}^{n}\left(y_{i}-\bar{Y}\right)^{2}, 1 / 2\right)\right.
$$

The independent variable with the highest correlation with the response variable will enter as it will yield the highest R-squared. R-squared is defined as the Sum of The Squares due to regression divided by the Total Sum of Squares,' corrected for the mean. The stepwise program performs a partial F-Test on each of the variables. in the model at each step of the program to determine whether the highest partially correlated independent variable not yet in the model should enter or whether after a new variable enters others already in the 
model should be removed. The F-Ratio determined by appropriate quotients of the Mean Sum of The Squares is compared to a critical $F$ whose value is a civon in statistical I tables for differins degrees of frecdom for. the numerator and denominator. (19)

The standard error of estimate is a measure of the spread of the observed data points about the regression line.

With this synopsis of statistical measures, a discussion of model development will follow.

Of the one hundred two interchanges surveyed a complete data set of 13 base variables, excluding the Economic Shift Index, was available for 82 interchanges. A multiple stepwise regression was run for these 82 cases. The thirteen base variables were entered along with the transformations, such as log 10, square root, and square which seemed appropriate after plotting the dependent variable versus each base independent variable and interaction terms of the same base variables and transformations which seemed lorical. The correlation matrix of 31 variables indicated that ramp volume and crossroute volume each in its nontransformed and noninteraction base state had the highest correlation with both the unweighted and weighted dependent variables. The results of the best weighted and unweighted models at F.25=1.35 (a $25 \%$ probability that we would observe a critical F-Value exceeding 1.35) for 82 cases are as follows: 
TABLT 4

INODEI I RESUITS

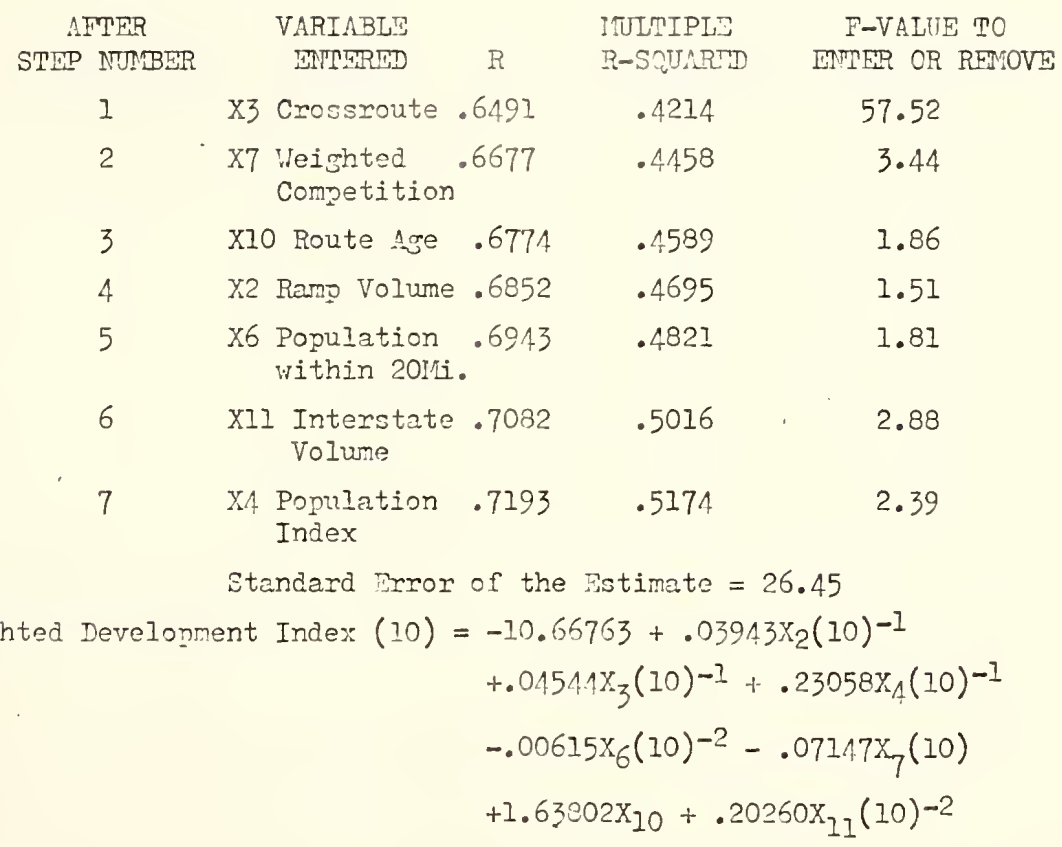


TABLE 5

MODEL 2 RESULTS

\begin{tabular}{|c|c|c|c|c|c|c|}
\hline & FTIRP & & VARIABLE & & IULTIPLE & F-VALUE TO \\
\hline STEP & NUNBER & & ENTEERED & $\mathrm{R}$ & R-SQUARED & ENTER OR REMOVE \\
\hline & 1 & X3 & $\begin{array}{l}\text { Crossroute } \\
\text { Volume }\end{array}$ & .6332 & .4010 & 44.59 \\
\hline & 2 & & $\begin{array}{l}3 \text { Unweighted } \\
\text { Competition }\end{array}$ & .6410 & .4109 & 2.75 \\
\hline & 3 & $x 4$ & $\begin{array}{l}\text { Population } \\
\text { Index }\end{array}$ & .6533 & .4268 & 1.37 \\
\hline & 4 & & $\begin{array}{l}1 \text { Interstate } \\
\text { Volume }\end{array}$ & .6604 & .4362 & 2.46 \\
\hline & 5 & & $\begin{array}{l}\text { Population } \\
\text { Within 20Mi. }\end{array}$ & .6680 & .4463 & 3.57 \\
\hline & a Devel & & $\begin{array}{l}\text { andard Errox o } \\
\text { nt Index (10) }\end{array}$ & $\begin{array}{l}\text { f the } \\
=-2.3 \\
-.05 \\
+.09\end{array}$ & $\begin{array}{l}\text { Estimate }= \\
2037+.042 \\
259 x_{13}(10) \\
988 x_{11}(10)\end{array}$ & $\begin{array}{l}.83 \\
x_{3}(10)^{-1} \\
+.19978 x_{4}(10)^{-1} \\
-.05259 x_{6}(10)^{-2}\end{array}$ \\
\hline
\end{tabular}

The R-Squared is only .4463 and so the veighting of development seems to add to the model's fit and is the oniy altemative considered hereafter.

At this juncture, with such a low R-Squared and with the residual plot of the dependent variable being somewhat linear, two changes were made. First, the interchanges of the urban and suburban classes were removed from the 82 cases leaving 63 more normal but with less variation and then the Economic Shift Index base independent variable was added necessitating removal of 11 more data points leaving 52. As noted, this class of interchanges remaining was felt to closer approximate the linear regression assumptions. The results of the best model with $F .05=3.98$ at this disagrregated level is: 


\section{TABIT 6}

FINAL MODEL RESULTS

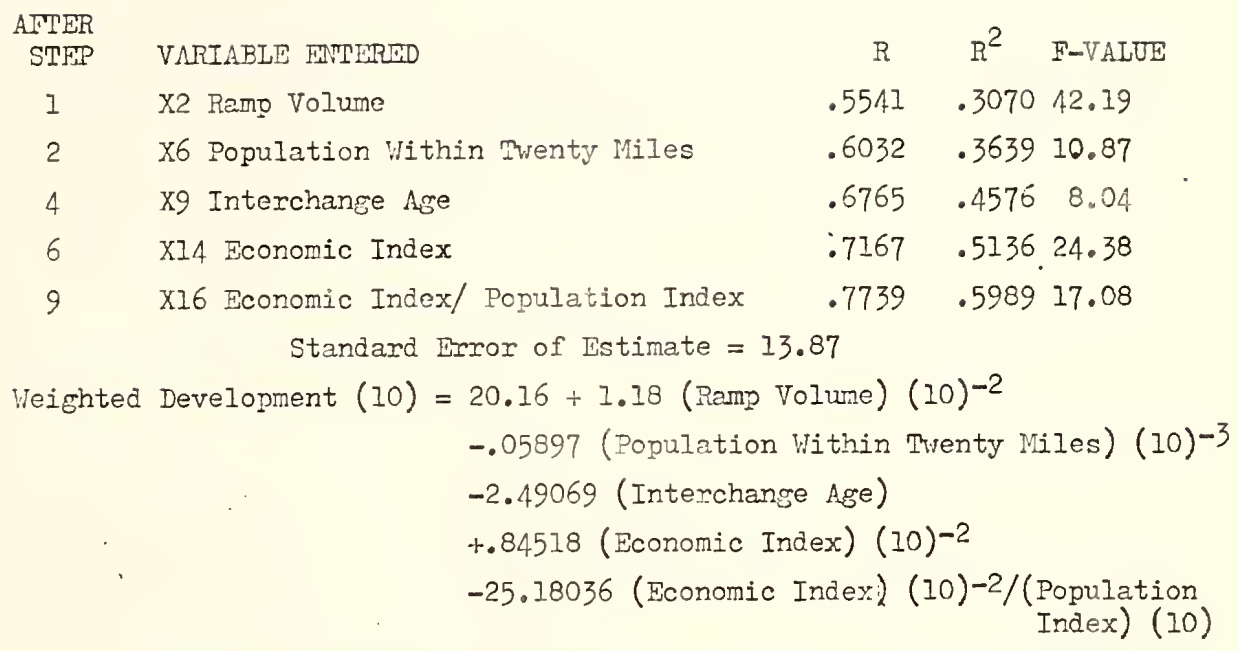

Although an aggregate land use development model with R-Squared equal to .5989 might ordinarily be considered satisfactory, because of questionable parameters and two highly theoretical variable indexes, the land use development variable and the above model should be further refined before being used for specific land use development predictions. However, the above model is the best model that can be developed with the ageregate data collected without adding extensive additional data collections of trip reneration by land use type to refine development weights and to identify other causal independent variables. In adidtion, the normality plot of the residuals in Appendix $E$ leads to the conclusion that this model is still lacking some as yet undiscovered linear factor or linear interaction. 
CHAPTIR VI

INTERCHANGE CASE STUDIES

The following case studies will progressively subjectively show, where the regression modeling of the past chapter objectively cannot, that interchange area land development is inevitable, sometimes very explosive, and should be carefully planned for, especially in suburban interchange areas where growth is active and planning could still be useful.

To be comprehensive this discussion will begin with the least critical rural interchange classification. In these areas there presently exist no immediate land use dangers to the traffic capacity of the interchange ramps and of the crossroutes. Review of development plans at the District and at the State Highway Commission levels have successfully kept driveway outs for roadside development a safe distance (100') avay from ramp terminals.

It was found that many establishments in these rural areas desire the visibility and the related free advertisine offered by plots adjacent to the Interstate interchange right of ways. Nevertheless, througin their ow initiative, restricted by access rights a distance along the crossroute frontage, or in cooperation vith traffic permit and planning review boards they have located their crossroute access points safely out of conflict with rasn terminals.

Neither ramp congestion associated with crossroute blockage and with ramp terminal traffic signal controls nor ramp safety problems associated with nearmess and conflict of first crossroute driveway or roadway access after a ramp terminal are problems at this time. Second and additional driveway or roadway access points, their spacine, and frequency alone the crossroute as pertinent to crossroute congestion, delay, and safety are not presently problems either. 
However, to let the next few years pass without active interchange area planning and enforcement in implementing controls could be disasterous when comparing the small required expenditure for land use planning to the potential loss of existing interchange structural investments as well as lost interim interchange area land investment.

The situation is quickly approaching or has already approached a critical state in suburban interchange areas without adequate long range interchange area planning. At the interchanges the familiar commercial strips, existent on major urban arterials and on urban bypasses and often correlated with past and present hazard-throughtoo-frequent-direct-access-to abutting-land, is found growing along suburban crossroutes leading to nearby urban centers. Surburban interchange areas chosen for illustration and brief commentary are the junctions of Interstate 65 and State Route 46, of Interstate 65 and U.S. Route 50, of Interstate 70 and U.S. Route 231, of Interstate 74 and State Route 44, of Interstate 69 and State Route 8 , and of Interstate 74 and State Route 3. The order of presentation is deliberately planned to roughly start with the least developed interchange area in an effort to subjectively establish a progression from one extreme of development to the other extreme. 
CASE I: Interchange of Interstate 65 and State Route 46

This interchange area is in what could be considered an early stage of strip development extending out from Columbus west to the Interstate 65. The existing initial development is concentrated with frequent direct crossroute access to predominantly road user services imnediately adjacent to Interstate right of way boundaries in the Northeast and Southeast quadrants. However, as land develops in the present gap between urban Columbus and the Interstate and as the Northwest and Southwest quadrants begin to develop more densely than present scattered residential plots amid agricultural fields, the already heavy volume on dual lane State Route 46 may become significantly congested during peak travel periods. With Cumins Diesel, a major employer in Columbus relocating at the next Interchange south on Interstate 65 and with the many recreational opportunities of neighboring Brow County to the West, Columbus' growth in the near future to the West and to the South should at least equal recent growth to the North and to the East. Growth at this interchange has proceeded at a steady rate since its opening in 1962. An anticipated crosssection of four moving lanes for SR46 was wisely planned for its grade separated crossing with Interstate 65; but, a plan must provide for proper setback and right of way purchase along the crossroute between the Interstate and Columbus. 


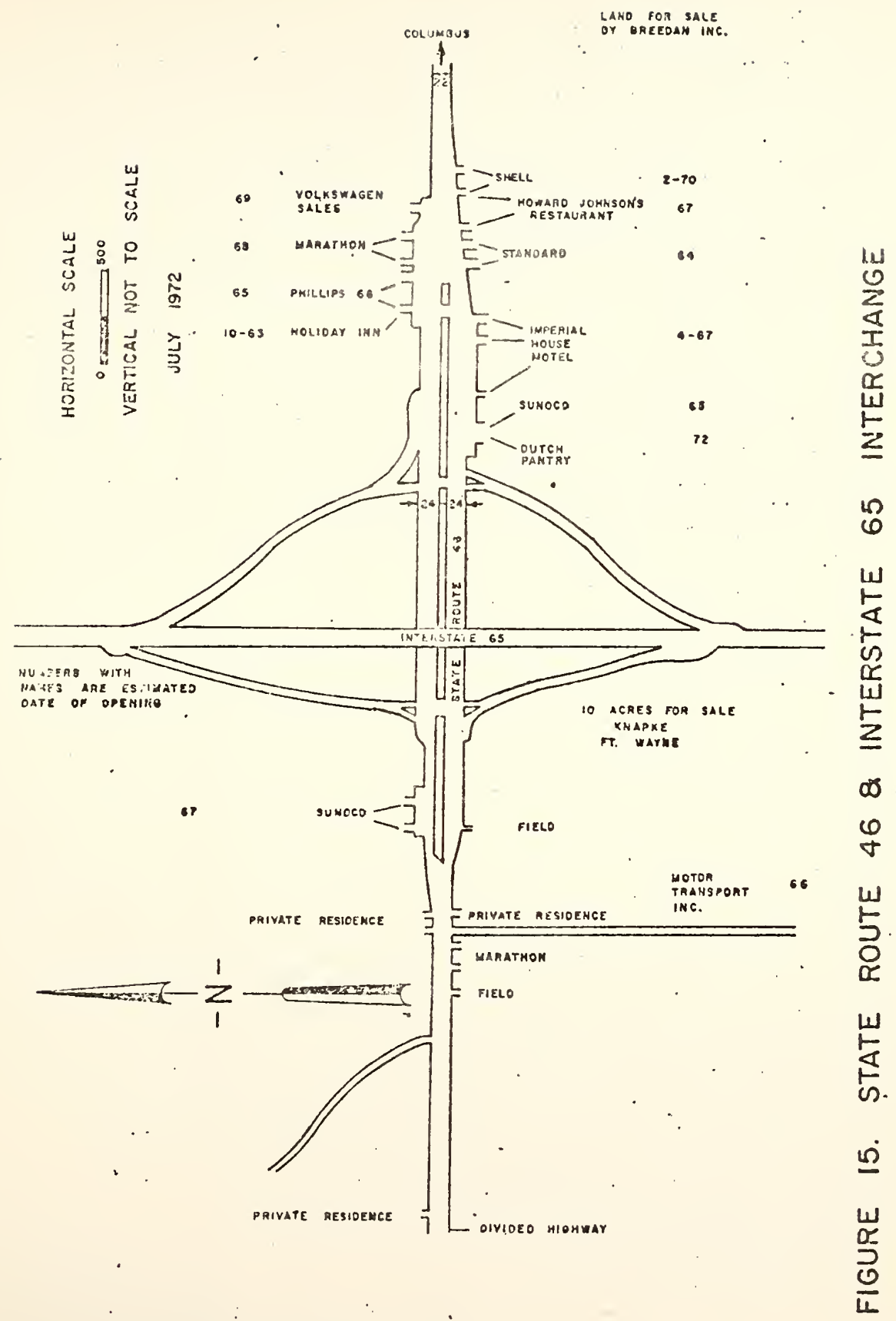


This interchange, open since 1961, did not develop at first with a drive-in theater, restaurant, and a gasoline station therc much before the Interstate, constituting the only investment activity until 1965. 1965 marked the beginning of extensive development up to the present time. Road services located during the 1965 through 1968 period, with surburban offices, a church, and a neighborhood shopping center related to the expansion of Seymour toward the Interstate being the uses developing since 1968 .

In this case a four lane crossroute highway west of the Interstate into Seymour, desigmed with limited median crossing points, displays intelligent interchange area planning. However, many closely spaced driveways show in the Northwest quadrant of the interchange along U.S. Route 50 on Figure 16 creates a potentially hazardous segment of roadway near a high speed freeway exit. 


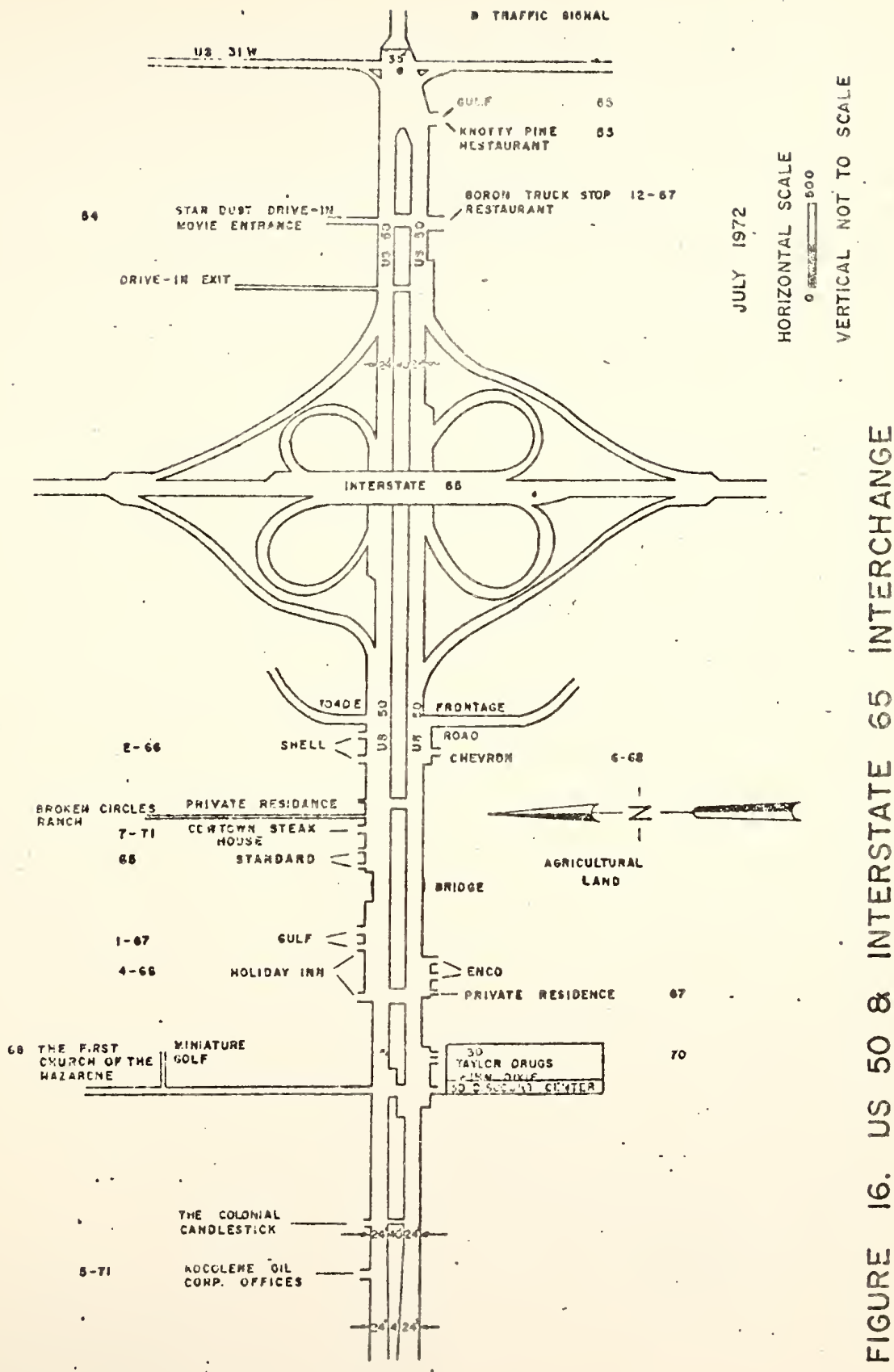


The crossroute, U.S. Route 231 is a major north-south route in westem Indiana. Of the land use surveyed in the intcrcharme area the earlier development was surburban residential and agricultural business and only after the 1966 interchange opening did the highway oriented land uses of gasoline stations, motels, and highway maintenance buildings appear in a wave. This in turn pronoted further resicential building in the area. At this interchange the strip development into the nearby city, Crawfordsville, is much farther along reflecting U.S. Route $2 z^{\prime}$ 's importance in intercity transport prior to becoming a feeder route to Interstate 74 .

The Interstate grade separated structure and the crossroute development setbacks appropriately anticipate the day when volumes will warrant a four lane facility for U.S. Route 23l. A service road for residential development in the Southeast quadrant represents sound planning in collecting and delivering vehicles to two entrance points at the crossroute more than 1000 feet apart. It is unfortunate that access to the crossroute was not similarly controlled at the comnercial development nearer to the Interstate ramp terminals. 


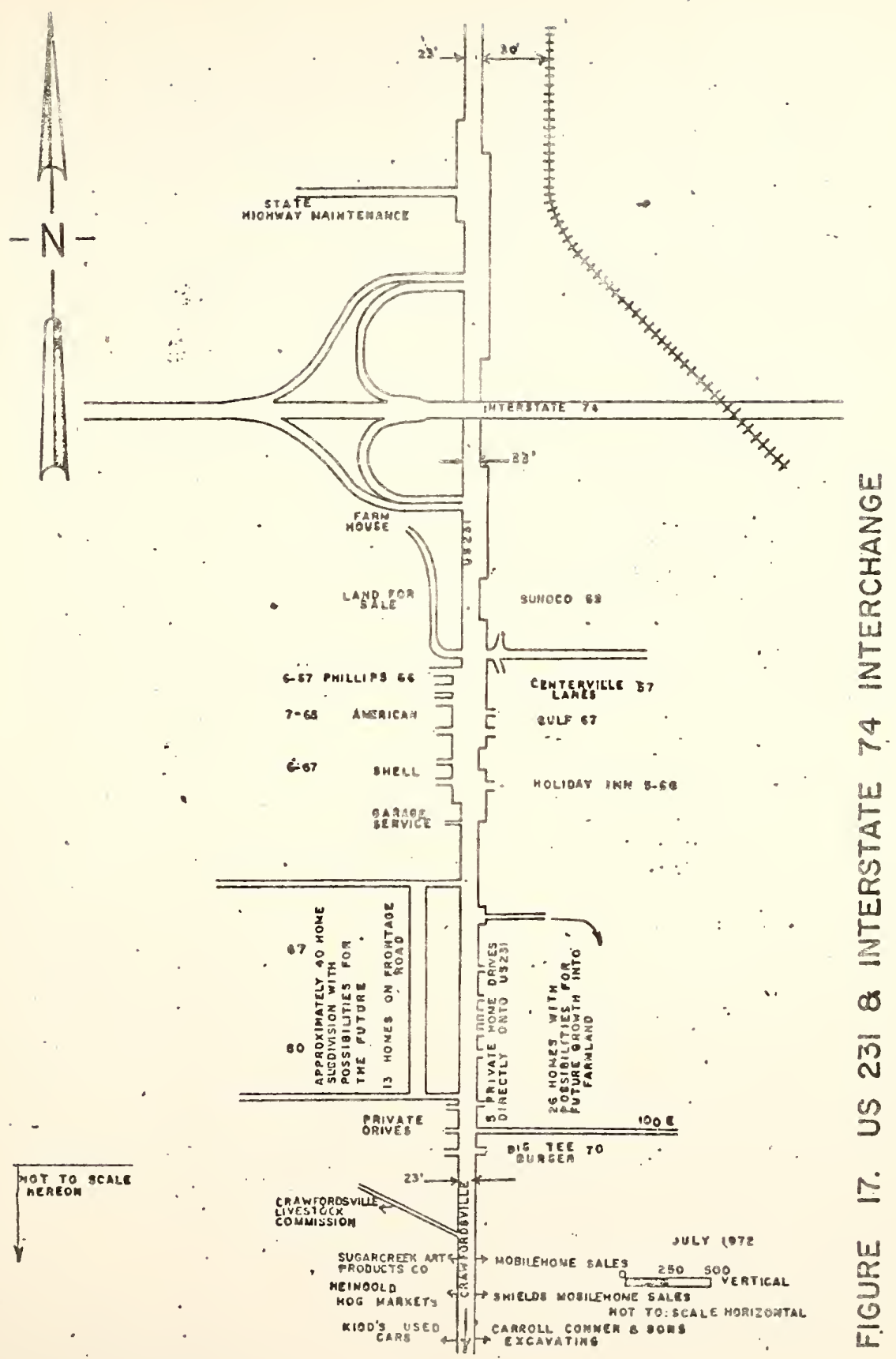


This interchance opened in 1961 offered access to nearby She thyrile in addition to the Farm Coor and the General Elcotr? plant (Figure 18) already in the area. With the interchange access and a nearby industria] plant it is surprising that gasoline stations only located after a neighborhood shopping center was built in 1965 in the Southeast quadrant. General Electric expanded its operation in 1969 and since then studios, sales rooms, food marts, and additional retail operations have located in this area to take advantage of trate? exposure and convenience though some have since closed.

Restricted by a seldom used railroad track to one side of the crossroad the interchange design chosen connects all ramp teminals at the east side of the crossroute. No land use transportation problems exist as the area is characterized by large land extensive industrial and business uses with few safely spaced access points along the crossroute. Although land coverage is greater than past case study examples, controlled crossroute access points reduce the potential hazards of crossroute conflicts. 


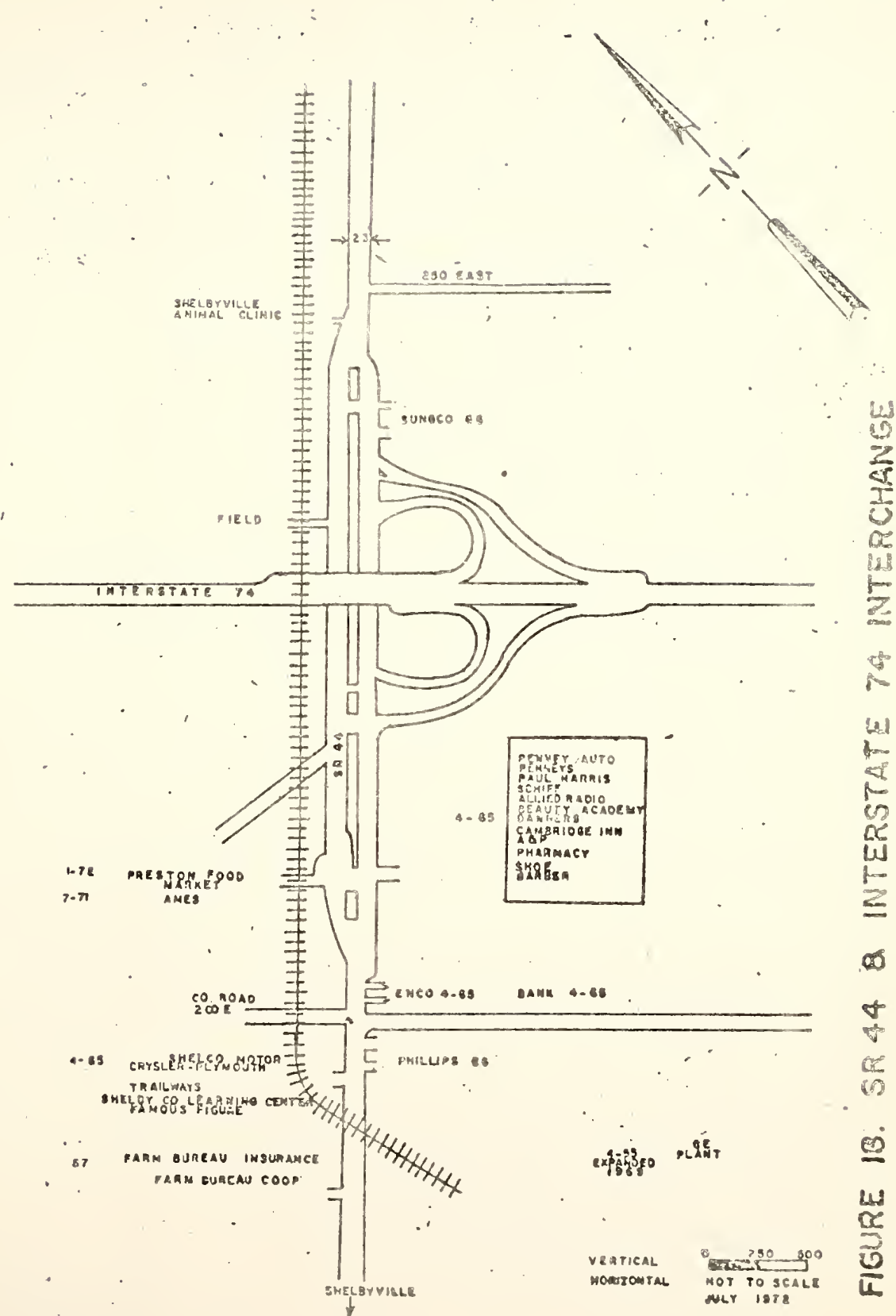


This interchange area was found to be very densely developed with residential, comercial, and industrial land uses in a suburban area of a Erowing urban center, Aubum, whose 1970 population was 7350.

The timing of growth should be dramatic proof of the necessity for interchange area land use planning as part of highway planning in any similar suburban area. Before the Interstate and the interchange were opened in 1964 primarily residential homes lined State Route 8 into Aubum. There were also some very old established industrial plants located adjacent to the railroad tracks shown crossing State Route 8 in Figure 19. Small businesses requiring considerable inexpensive land moved out from Aubum accompanying the usual initial post Interchange wave of gasoline stations and motels. A rather large mobile home park when added to the importance of State Route 8 as an intercity route has steadily demanded more community services and created a stable narket to support added gasoline stations, restaurants, drug stores, and two forthcoming neighborhood shoppine centers.

The time between a general survey taken in January 1972 and a detailed survey undertaken in July 1972 saw three future high traffic generators (two shopping centers and an industrial park), a possible short order restaurant, and a completed drug store suddenly come into the development picture. Although the highway grade separated structure again provides for four lane operation, the critical segment between Auburn and the Interstate exhibits very little widening, driveway, nor land use planning.

Since East-West State Route 8 is the only major route through Auburn, future Erowth can reasonably be expected to continue along this band. 


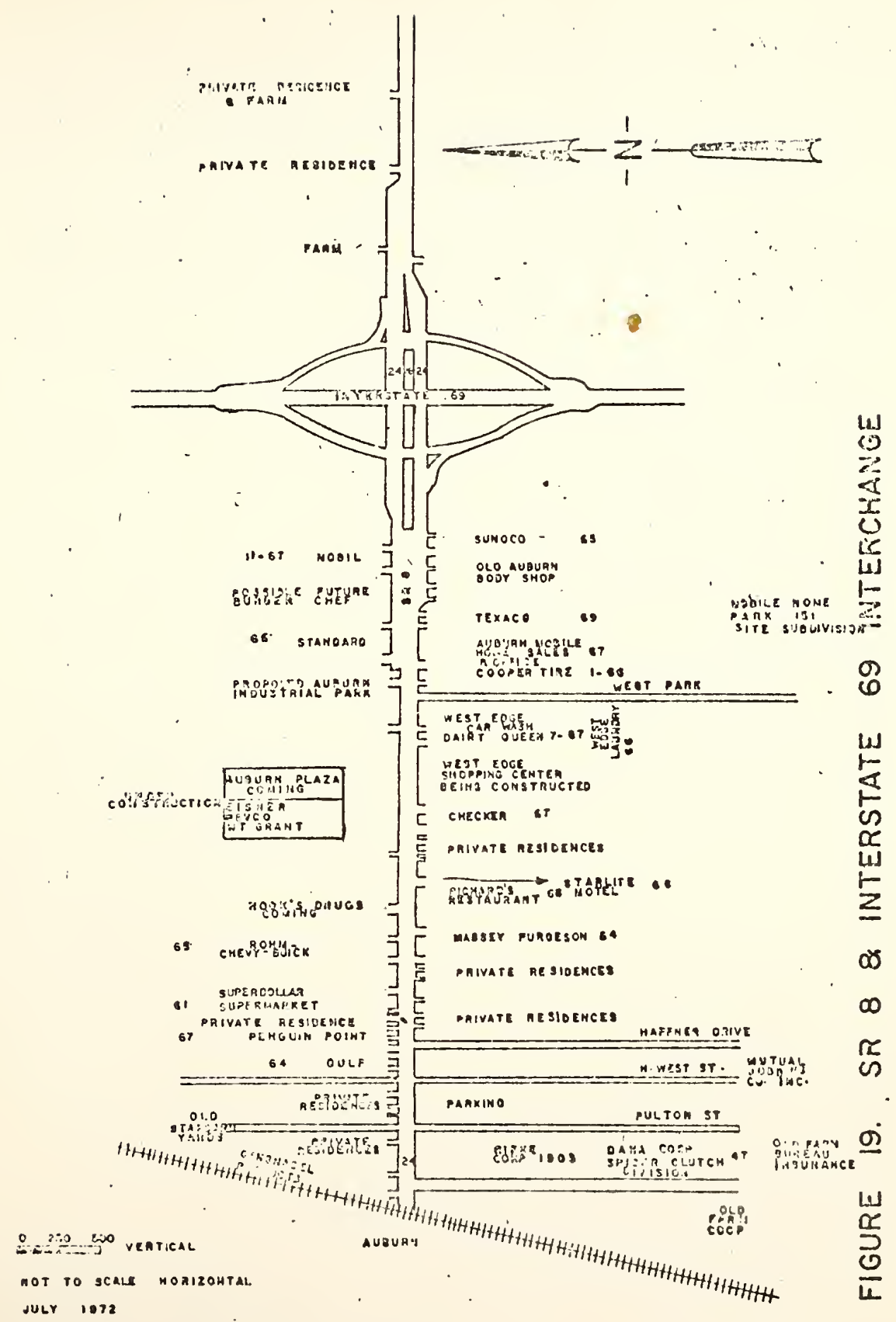


Greensburg has grown out along State Route 3 before and since Interstate 74 was opened in 1963. But, in contrast to other interchange areas many community services were established even before the Interstate was opened. Since $90 \%$ of this preinterstate construction occurred from 1960 through 1963 it might have been stimulated by anticipation of State Route $3^{\prime}$ 's new function as the main access route connector to Greensburg. On the other hand, this growth could have been an outcome of natural urban development, a difficult distinction to make in evaluating Interstate economic impacts versus urban growth impacts.

In either case road user gasoline services still constituted the majority of post Interstate development. Also, in light of the amount of residential development already present, neichborhood shopping centers sprang up almost immediately. Therefore, the frontage along the crossroute leading into Greensburg is presently saturated with mixed road user, residential and local goods sale establishments with frequent driveways affecting crossroute service volumes.

With all these driveway conflicts and the potential development north of the Interstate, though temporarily halted by the urban boundary the Interstate seemingly forms, in addition to present continuing growth in the Southwest and Southeast quadrants back from existing crossroute strip development, State Route 3 may become the new "Main Street bottleneck:" of Greensburg. 


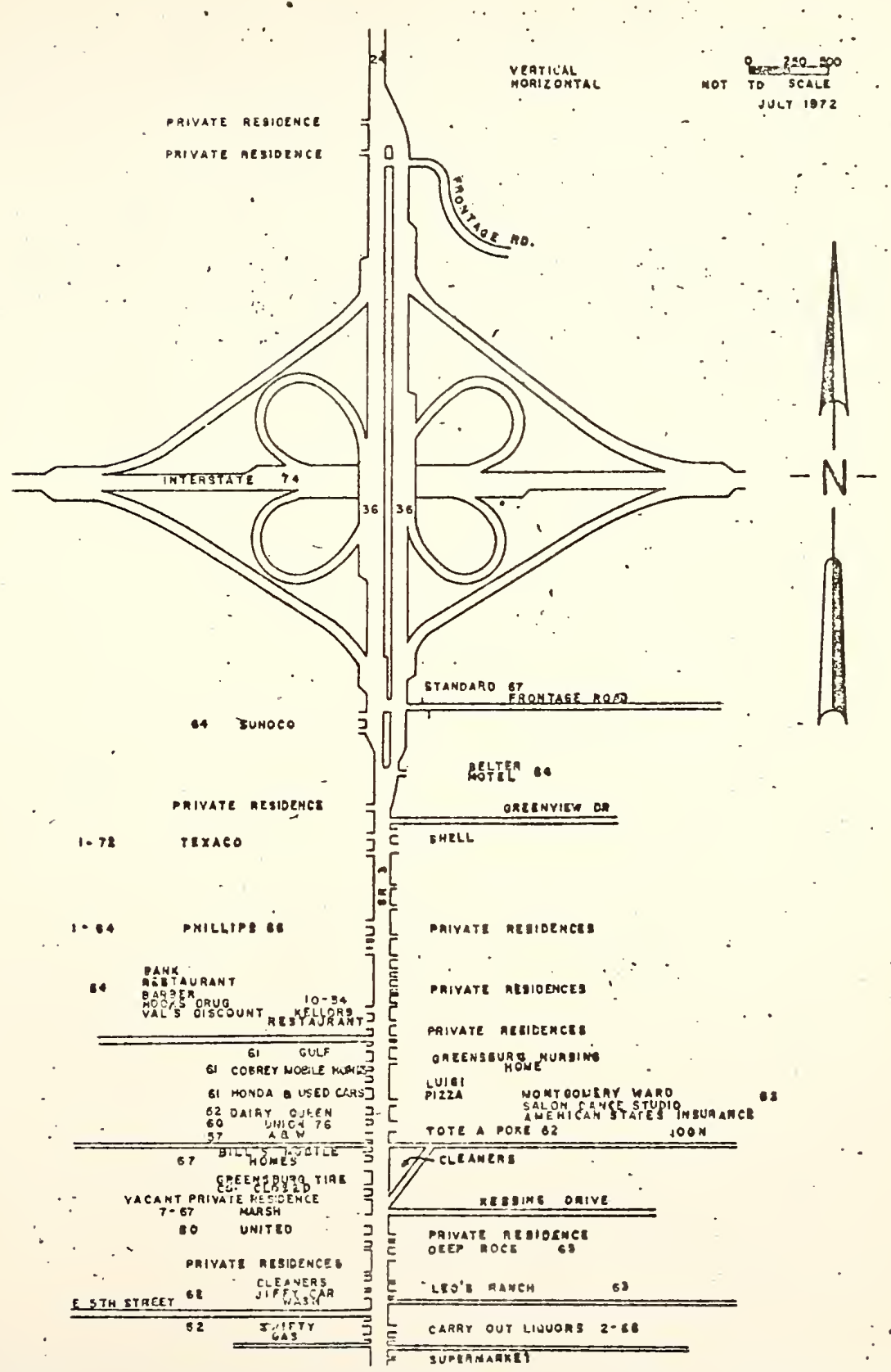

FIGURE 20. SR 3 \& INTERSTATE 74 EAST INTERCHANGE 
This concludes the case study progression of interchange development for suburban interchange areas. Although the observations are matter of fact, they prove conclusively that interchange land development will occur and should be planned for prior to the Erowth not post facto as is often the case.

Continuing now with four cases of urban fringe interchanges may give some added indication of what uncontrolled development effects may cause as an interchange area grows toward total nonagricultural use. The interchanges chosen from the urban fringe interchange classification are the junctions of Interstate 65 and U.S. Route 30, of Interstate 69 and State Route 3, of Interstate 70 and U.S. Route 41, and of Interstate 65 and U.S. Route 131. 
CASE VII: Interstate 65 and State Route 30

Since this major interchange in northerm Indiana has opened in 1968 the predominant new deve?opments in the area have been gasoline stations and a motel-office-restaurant complex. Earlier development west of State Route 53 and presently along State Route 53 is more properly attributed to the tremendous growth of Merrillville, Indiana in the past few years. The development to either side of the Interstate is excellently access controlled by frontage roads leading back to residential, commercial, or business establishments from one safely placed crossroute access point. Two new large developments are expected east of the Interstate and should have access control with respect to U.S. Route 30 so as to allow only one or two main access points requixing some form of traffic control. 


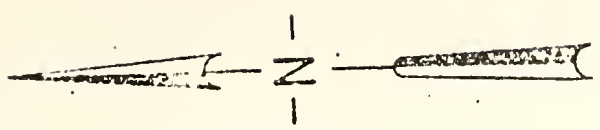
FUTIJRE CONMEMCIAL EDTE CTED SOON
SOO ACRES

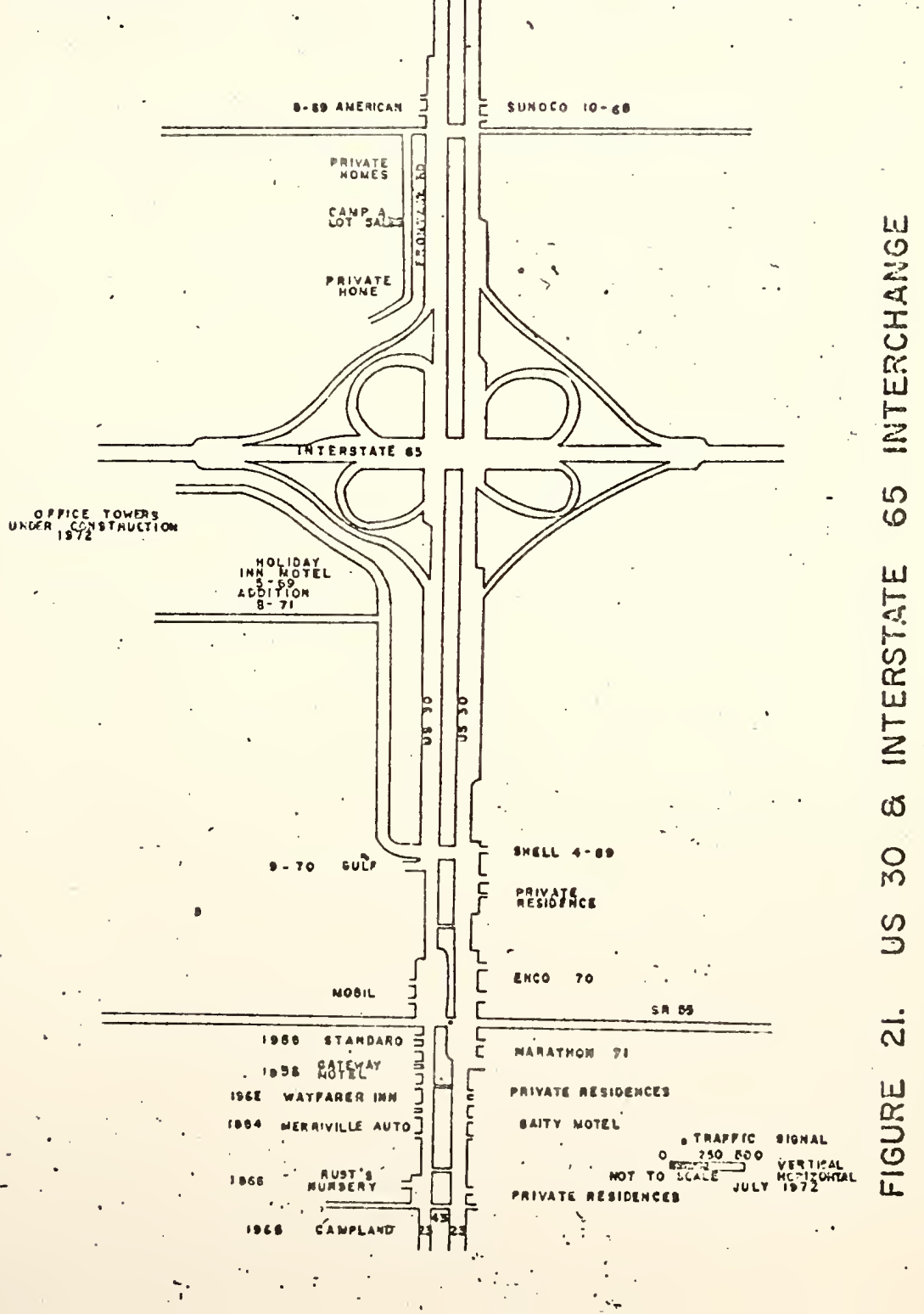


This interchange opened in 1962 with many industrial businesses, restaurants, or carry outs, and casoline stations near the east end of the survey area already existing. It took the added locational advantage of an Interstate to spur additional service stations, land extensive businesses (e.g., furniture and auto or mobile home sales), industrial parks and large single family subdivisions to the area since then.

Driveway entrances while very frequently spaced are minor conflict points since State Route 3 is a four lane divided roadway with auxiliary lanes for turning movements. Access to industrial develonment in the Northeast and Southeast quadrants is well handled by a simalized intersection on the crossroute with the only possible future drawback being that, with increased interchange usage, bachups from these signals along the crossroute may create a blockade of vehicles to confront a vehicle exiting from the Interstate ramp. Another saving feature of design of this interchange area is the collector road roughly parallel to the Interstate, in all quadrants, which collects traffic in a quadrant and distributes it to the crossroute at one point. However, these signalized points may again be too close to the off ramp temninals in this case with future delay and danger consequences possible as described above. 


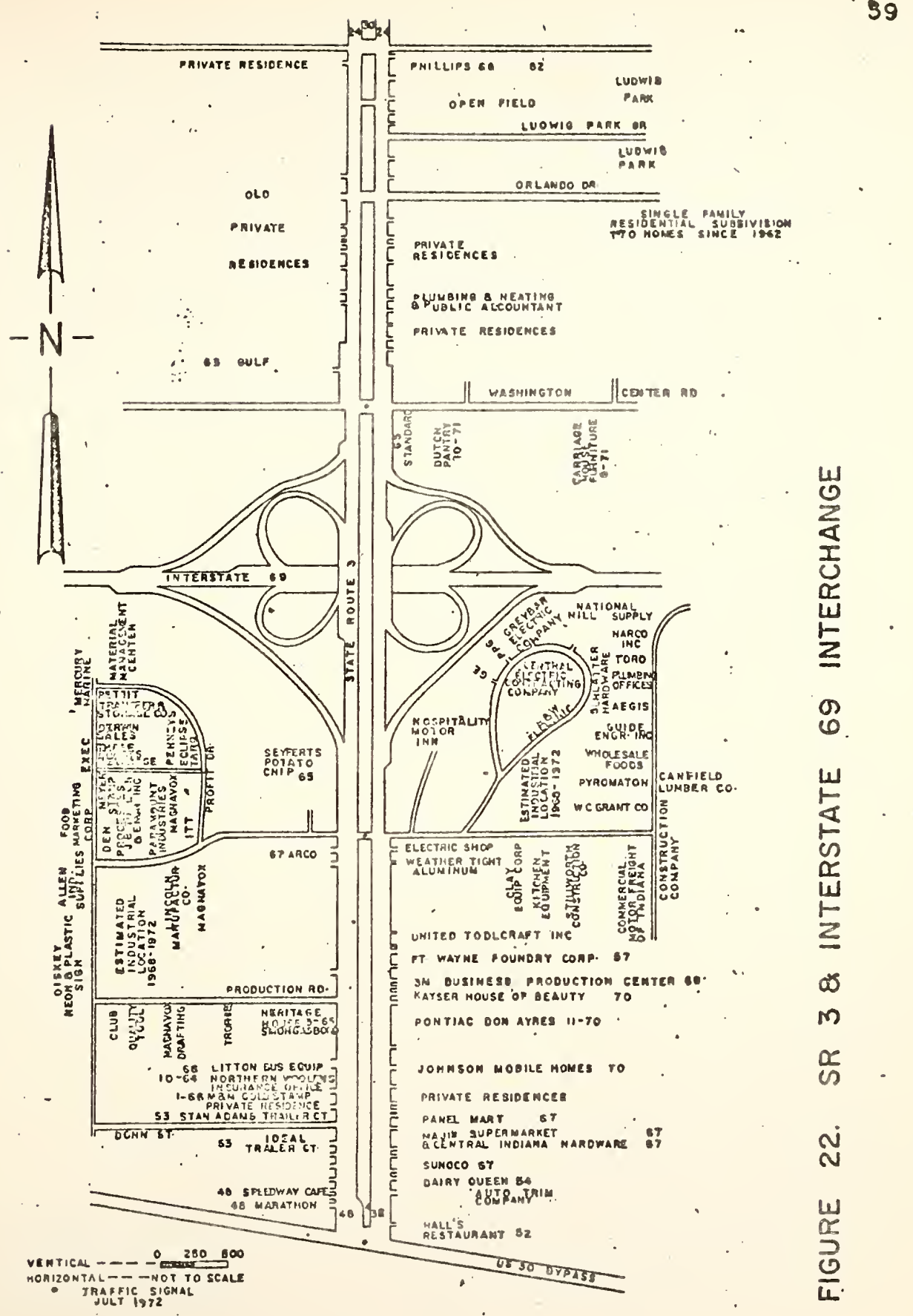


CASE IX: Interchange of Interstate 70 and U.S. Route $4 I$

As with Case VI urban development south from Terre Haute alons SR $41^{\circ}$ had virtually filled all land to the Terre Haute side of the Interstate before interchange opening. However, the south side of the Interstate followel a development pattern of first gasoline stations and motels, then mobile home sales, automobile sale rooms, automobile maintenance services, out of town show rooms, and finally a shopping center, in this case a regional shopping center. Unfortunately, with the exception of the recional shopping center and an as yet undeveloped 90 acre development tract all other access to U.S. Route 41 is on a "come-as-you-please-basis". The median strip, south of the Interstate, controls cross interferences but side drivevay interferences for each direction of travel still exists.

Ranp terminals are signalized which may become a problem when other nearby crossroute signals in place or warranted in the future are interconnected to provide satisfactory traffic progression through the area. 


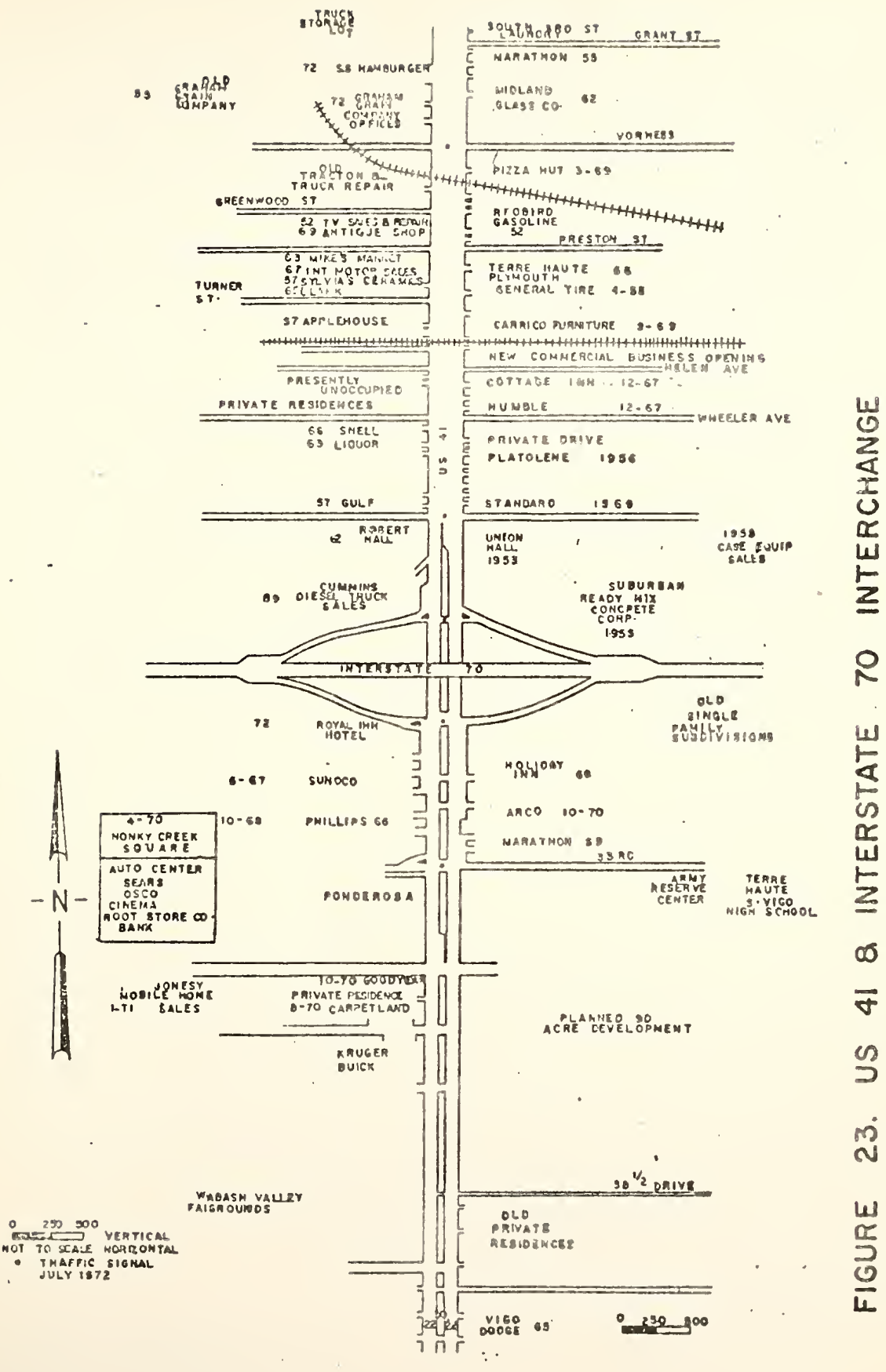


Although this interchange was opened as part of the old 0.S. Route 31 alignment, the area's development has cxploded since 2965 with gasoline stations, car sales, service businesses, carry-outs, restaurants, mobile home sales, neighborhood shopping centers, and then regional shopping centers. Industrial parks and related road user establishments will be sure to utilize remaining undeveloped tracts east of the Interstate which features a railroad with several sidings already existing.

The interchange type is a partial cloverleaf with the on and off ramp terminals side by side on one side of the crossroute. Old heavy industrial development and more recent comercial development exist very close to these ramp terminals. Interstate right of way is so restricted in the Northwest quadrant that an access road to a hotel and to a service station terminates on the combined on-off ramp in that quadrant. Any modification in the existing interchange structure already restricted by a truck stop and railroad tracks in the Southeast quadrant and a large chemical plant and truck stop in the Southwest quadrant would be extremely costly at this late date. 


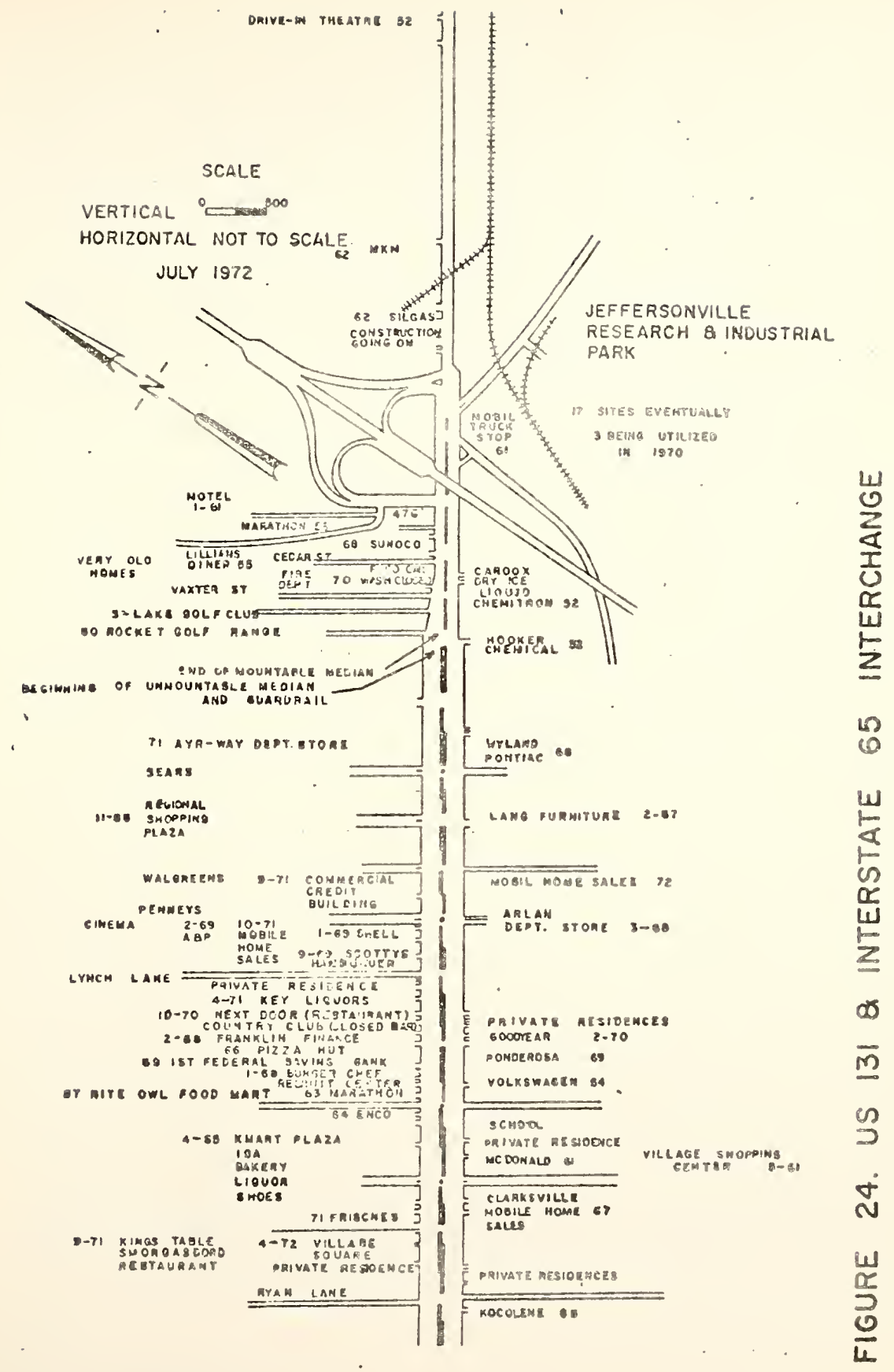


With the preceeding examples a progression of development at interchancres can be reasonably be hypothesized. The immediate effects of an interchange are an influx of gasoline stations, of truck stops, of motels, and of restaurants. Dependins on the extent of residential. srowth before and during Interstate constmetion car sales, furniture stores, office buildings, carry-out restaurants, and rclated enterprises dependent on residential or work markets can be expected either imnediately or as a sccond stage of development. Iikevise, neichborhood shoppine centers can be expected in every suburban interchange area and both neighborhood and regional shopping centers can be expccted at urban fringe interchange areas. Industrial parks or industrial rolated businesses are more likely expected at urban fringe interchanges. As was discovered in modeling, there is no one consistent land use development staring which can be described exactly by mathematical equation. Some interchange areas have community uses before road service uses. Others have industrial uses which lead to sooner influx of residential, of shopping, or of recreational uses. And while the development, as shown by years in Tables 7 and 8 for our cases studied, cannot presently be precisely classified, matched, or quantified, it is likely that sone upper limit (saturation) of development is being approachod in the differing areas. It is also certain that in spite of high land speculation there is a great amount of logic in locating lanc uses in interchange areas. It seems more likely, however, that this location decision process is more a dynamic than a static process. To quantify dynamic processes of land use change would require much more data for submodeling than is available in Indiana. Therefore, until such modeling is possible, perhans the best use of the present reported data is as a record of the most developed interchange areas for use to plan for those interchanges not yet built or not as far along in the development process. This would provide for sensible recognition of the movement of business, residential development and industrial operations to new high exposure, highly accessible interchange areas. And, if development is planned, interchange growth can be economically beneficial to govemments, to developers, and to area users. 
tAgle 7. SUBURBAN INTERChANGES CURULATIVE LAND USE DEVELOPMENT

\begin{tabular}{|c|c|c|c|c|c|c|}
\hline $\begin{array}{l}\text { OPENING } \\
\text { DATE }\end{array}$ & 1962 & 1965 & 1966 & 1961 & 1964 & 1953 \\
\hline $\begin{array}{l}\text { CASE } \\
\text { STUDY } \\
\text { U:IITS } \\
\text { OF DEV. } \\
\text { AFTER }\end{array}$ & $I$ & II & III & III & 立 & III \\
\hline 0 YEAR & 1 & 4 & 5 & 2 & 8 & 16 \\
\hline I YEAR & 2 & 6 & 9 & 2 & 11 & 19 \\
\hline 2 YEARS & 3 & 9 & 10 & 2 & 16 & 20 \\
\hline 3 YEARS & 5 & 12 & 10 & 2 & 21 & 22 \\
\hline 4 YEARS & 6 & 12 & 10 & 8 & 22 & 23 \\
\hline 5 YEAIYS & 9 & 13 & 10 & 10 & 23 & 2.4 \\
\hline$G$ YEARS & 10 & 15 & 10 & 11 & 24 & 25 \\
\hline 7 YEARS & 11 & 15 & & 12 & 24 & 25 \\
\hline 8 YEARS & 12 & & & 14 & 30 & 25 \\
\hline 9 YEARS & 12 & & & 14 & & 26 \\
\hline 10 YEARS & 12 & & & 15 & & \\
\hline 11 YEARS & & & & 16 & & \\
\hline $\begin{array}{l}1972 \text { CONFLICT } \\
\text { POINS (1) } 10 \\
\text { VEHICLES) } \\
\text { PER CROSS } \\
\text { ROAD MILE }\end{array}$ & 29 & 24 & 22 & 21. & 40 & 41 \\
\hline $\begin{array}{l}\text { CLOSEST } \\
\text { CROSTIOUTE } \\
\text { ACCES POINT } \\
\text { TO ANY RAMP } \\
\text { TERAMINAL }\end{array}$ & $175^{\prime}$ & $250^{\prime}$ & $500^{\prime}$ & $175^{\prime}$ & $400^{\prime}$ & $250^{\prime}$ \\
\hline
\end{tabular}


TABLE 8. URBAN FRINGE INTERCHANGES

CUMULATIVE LAND USE DEVELOPMENT

\begin{tabular}{|c|c|c|c|c|}
\hline $\begin{array}{c}\text { OPENING } \\
\text { DATE }\end{array}$ & 1968 & 1962 & 1969 & 1961 \\
\hline $\begin{array}{l}\text { CASE } \\
\text { STUDY } \\
\text { UNITS } \\
\text { OF OEV. } \\
\text { AFTER }\end{array}$ & III & VIIII & II & $I$ \\
\hline O YEAR & 9 & 11 & 29 & 13 \\
\hline I YEAR & 12 & 13 & 37 & 15 \\
\hline 2 YEARS & 14 & 15 & 38 & 16 \\
\hline 3 YEARS & 16 & 18 & 41 & .18 \\
\hline 4 YEARS & 17 & 20 & & 21 \\
\hline 5 YEARS & & 24 & & 23 \\
\hline 6 YEARS & & 30 & & 26 \\
\hline 7 YEARS & & 36 & & 36 \\
\hline 8 YEARS & & 44 & & 41 \\
\hline 9 YEARS & & 51 & & 46 \\
\hline 10 YEARS & & 56 & & 52 \\
\hline 11 YEARS & & & & 55 \\
\hline $\begin{array}{l}1972 \text { CONFLICT } \\
\text { POINTS ( } 10 \\
\text { VEHICLES) } \\
\text { PER CROSS } \\
\text { ROAD MILE - } \\
\end{array}$ & 24 & 40 & 40 & 40 \\
\hline $\begin{array}{l}\text { CLOSEST } \\
\text { CROSSROUTE } \\
\text { ACCESS POINT } \\
\text { TO ANY RAAP } \\
\text { TERMINAL }\end{array}$ & $950^{\prime}$ & $325^{\prime}$ & $200^{\prime}$ & $\begin{array}{l}\text { ON } \\
\text { RAMP }\end{array}$ \\
\hline
\end{tabular}


Illustrated Interchange Area Planning

This chapter will now discuss the crailable planning tools and subsequently show how some of thcse tools used together might have changed an existing Case Study area.

On the basis of the field survey there appears to be no enforced land use controls for most interchange areas. Fxcept for such an absence, land use control should nomally have been input to any land use model's base calibration. Iand use controls cannot be disregarded in planning and will now be considered as the foundation of the following interchange land use planning discussion.

\section{Police Powers}

Among the police powers considered for use are zoning, subdivision, setback requirements, driveway permit, and official mapping.

"Zoning is the division of the community into zones or districts according to present and potential use of properties for the purpose of controlling and directing the use and development of the properties." The effective use of zoning should result in an interchange area with reasonable density, positive distribution, and little congestion. "Unfortunately zoning has been a dismal failure because of the widespread use of exemptions and ready approval of requests for rezoning." (12)

One study shows that "applications have about a $90 \%$ chance of being granted in the first application." (22) "Part of the problem is that administrators look upon rezone applications near interchanges with no special awareness of the problen of interchange congestion." (8) In addition, field experience (Figures 15 through 24) suggests that lot by lot review of building permits and of drivcway permits without the aid of an overall plan to give zoning a firm basis, results in a disfunctional land use conglomeration with frequent crossroute access as the final product of interchange area devclopment. In essence, short range decisions and exceptions will lead to long range problems.

The need for comprehensive planning makcs subdivision controls a favorable supplement to zoning control to achieve integrated interchange development. Subdivision controls specify development limits for lot arrangements, widths, length, depth, open space, water 
and sewer systems, and easements for utilities. Subdivision controls. can stipulate favorable crossronte access points, proper utilities, and safe property access to prevent critical crossroute conflicts near to other driver decision points and to keep land in interchange quadrants from becoming landlocked behind early post interchange crossroute strip development.

As subdivision controls are often only applicable down to a certain minimum number of lots and since zoning is weak by itself in controlling single lot land usage and layout, several other land use controls need to be included in an effective legislative package for . interchange land use control.

Setback control will provide economic altermatives of increasing crossroute capacity through added width when the need arises and will reiriforce zoning building placement requirements.

Official mapping of proposed widening or expansion for the future community street system if established wisely and democratically is a good long range planning prelude prior to establishing more detailed subdivision and setback controls.

Driveway permits can control the design, placement and spacing of driveway cuts from, abutting properties to a public road and in conjunction with subdivision and zoning controls could adequately prevent crossroute and ramp terminal conflict problems if enforced by knowledgable review boards.

Enforcement is a chief drawback to successful use of police power land use controls and so there is pressure to use more powerful land use control measures. These measures include eminent domain and special interchange districts.

\section{Fminent Domain}

Purchase and leaseback is a powerful though unpopular method of controlling land use at interchanges. Purchase of development rights or conservation easements are somewhat more fair to land owners and more acceptable to enforcement officials and legislators. 
Excess condemnation when used by itself or in conjunction with a resale "for public purposes" as in urban reneval is another very effective power for controlling development. But, as evidenced by the numerous court suits claiming invasion of private rights, the faimess of widespread use of this power with regard to individual rights is not at all resolved. Economic and political costs and touchy legal bases are strong factors suggesting that interchange planners use this control on an extrcme-need-only-basis.

The most acceptable type of eminent domain appears to be the purchase of access rights along the crossroutes. Accepted design techniques can then be used to control the number, type, and placement of access points.

\section{Soecial Interchanee Area District}

Special districts, with precedent from waterfront districts have been suggested as a compromise way to stop scavenger speculation when the interchange and Interstate rights of way are first announced and to serve as an interim state control until the local planning commission does or does not act within a set time period.

With this brief sumary of available land use controls and their potential use in interchange area planning and with the background of case studies development presented earlier, this chapter will culminate in an illustration of how Case Area $V$ might have been planned. The final plan is not presented as the only design and control altemative but simply to demonstrate the use of good planning techniques. The trip generation rates used by type of establishment to demonstrate the number of driveway and of other crossroute conflicts are considered realistic estimates; hovever, while rates will be consistent for the planned and unplanned case, there is no attempt to substantiate these trip rates as the actual rates. As noted in the modeling phase of this research, rate detemination would require an extensive field Origin- Destination Field Survey not within the capabilities of this research study. 


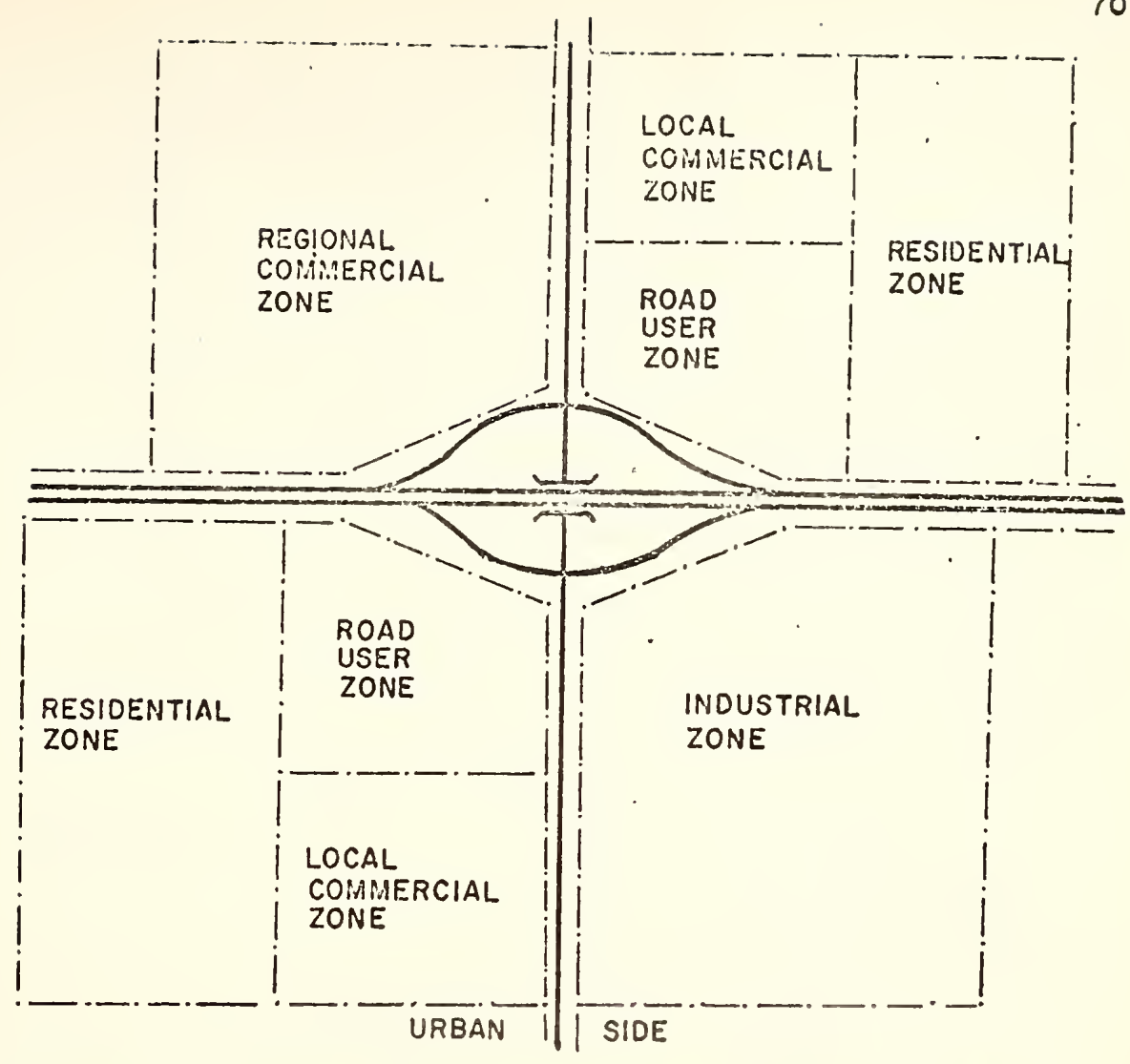

FIGURE 25. ZONING IN INTERCHANGE AREA PLANNING

Recognizing existing demands for land as tabulated in Chaptero Four and Six this sample zone scheme has the following advantages over mixed development:

1. Road user services have first access off with right turn access.

2. Peak late afternoon work volumes are put to the urban side and on the opposite side peak early afternoon and evening shopping volumes to minimize peak travel and conflicts in the ramp terminal areas.

3. Residential zones are buffered from high generator land use types serving all classes of vehicles. 


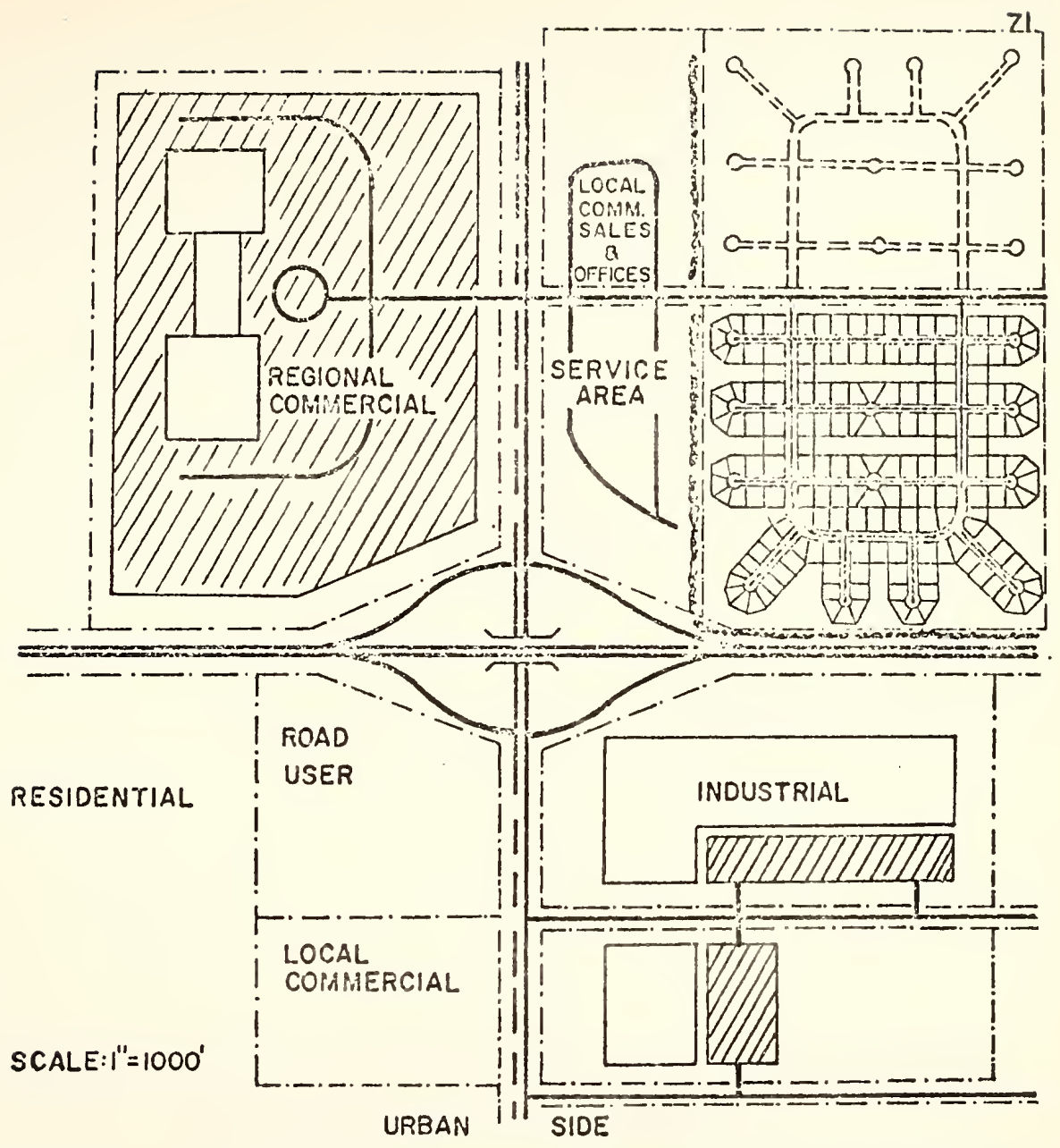

FICURE 26. OFFICIAL MAPPING AND SUBDIVISION IN INTERCHANGE AREA PLANNING

\section{Official Mapping:}

1. Rights to roadway right-of-way within reasonable number of years for new and additional public roads and utility easements.

\section{Subdivision:}

1. Layout of lots, parking, streets, and utilities for subdivided plots of all land use types. 


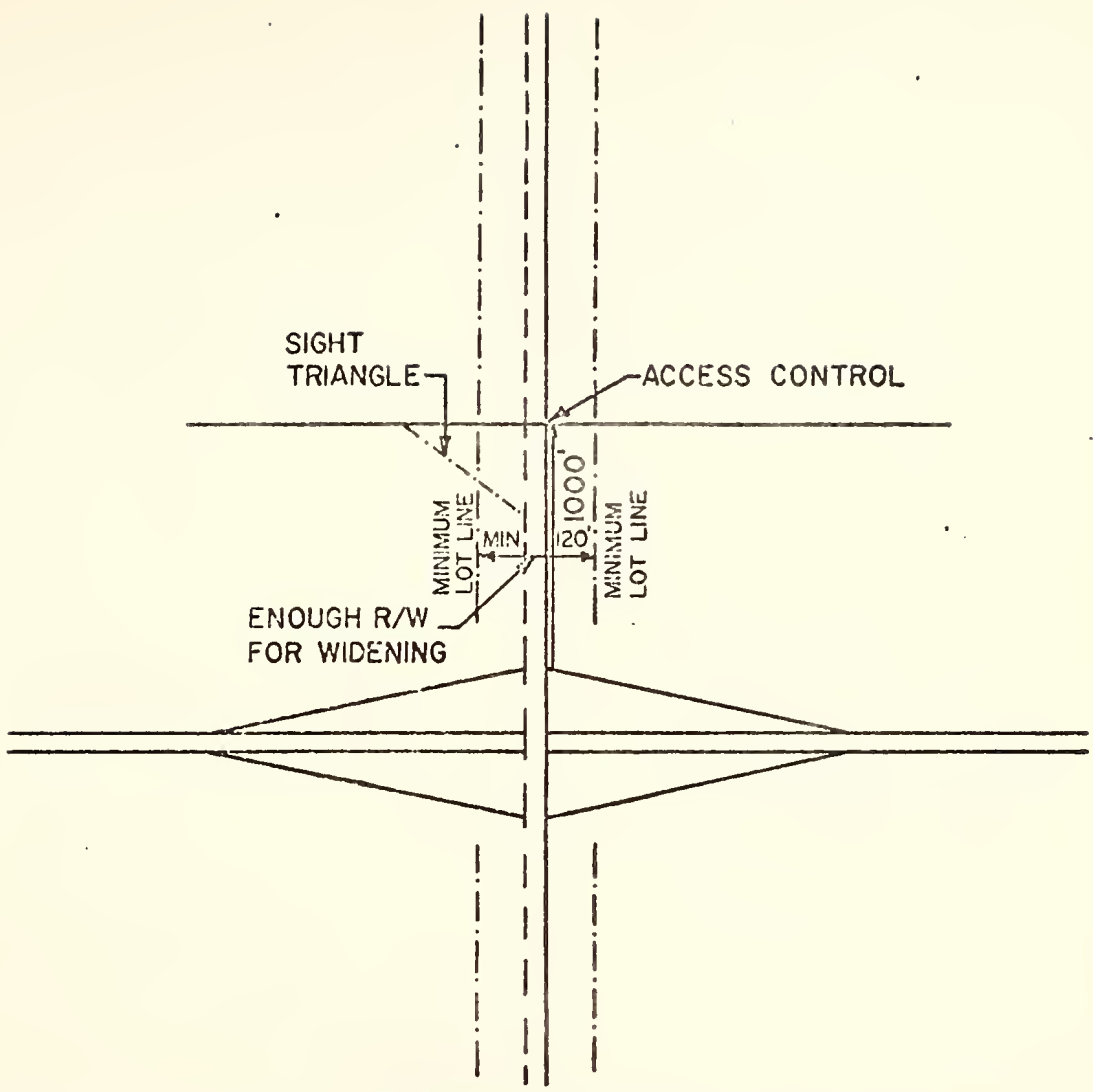

FIGURE 27. SETBACK REQUIREMENTS AND DRIVEWAY PERMITS IN INTERCHANGE AREA PLANNING

Setback Requirements:

1. Provides width for widening or for service roads.

2. Provides unobstructed ramp terminal views.

Driveway Permits:

1. Allow access review in light of entire interchsnge area plan. 


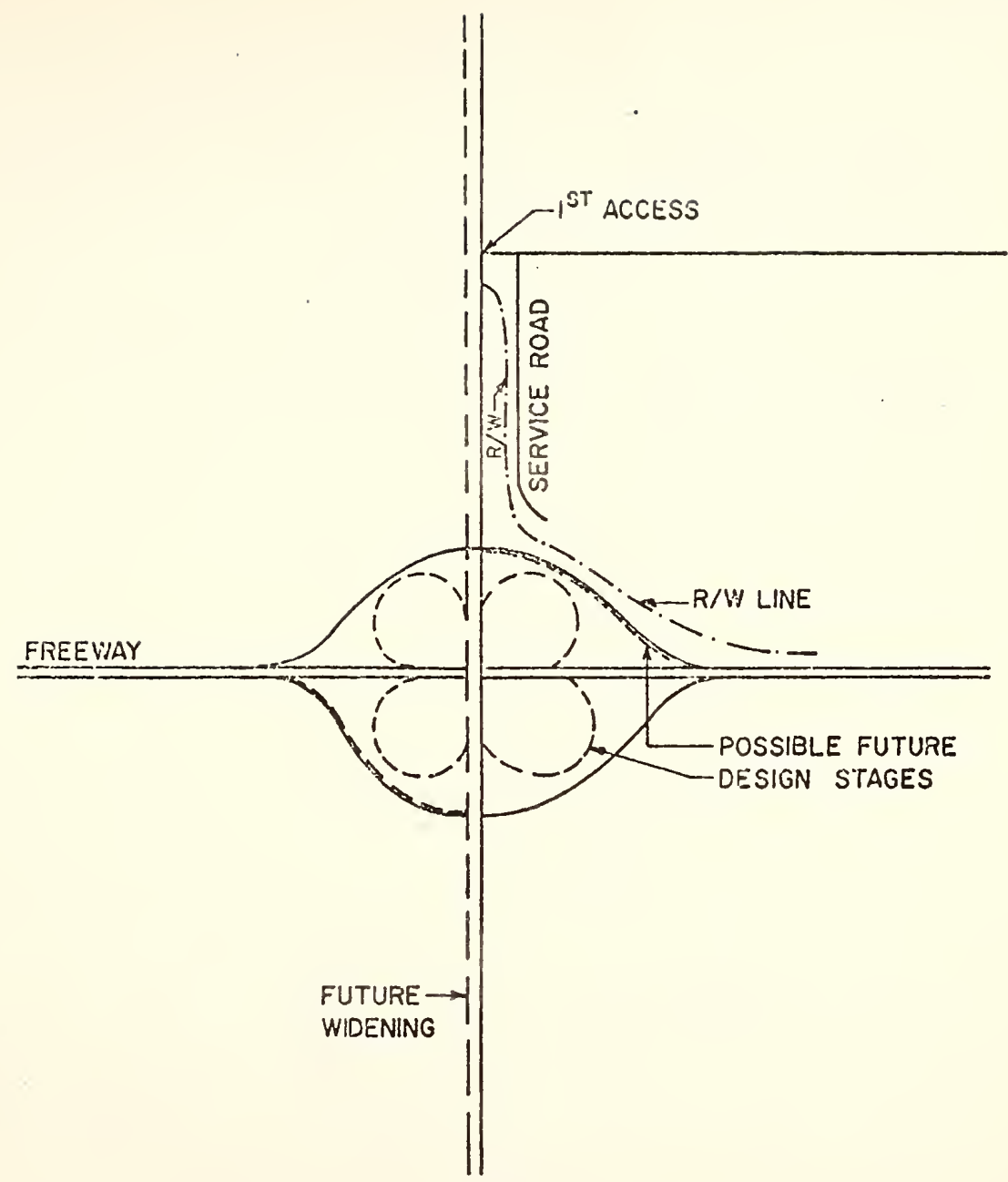

FIGURE 28. DESIGN CONTROLS IN INTERCHANGE AREA PLANNING

Design Options:

1. Flexible inftial interchange area design

a. Control crossroute access points

b. Allow for economical design expansion to meet increasing capacity needs. 


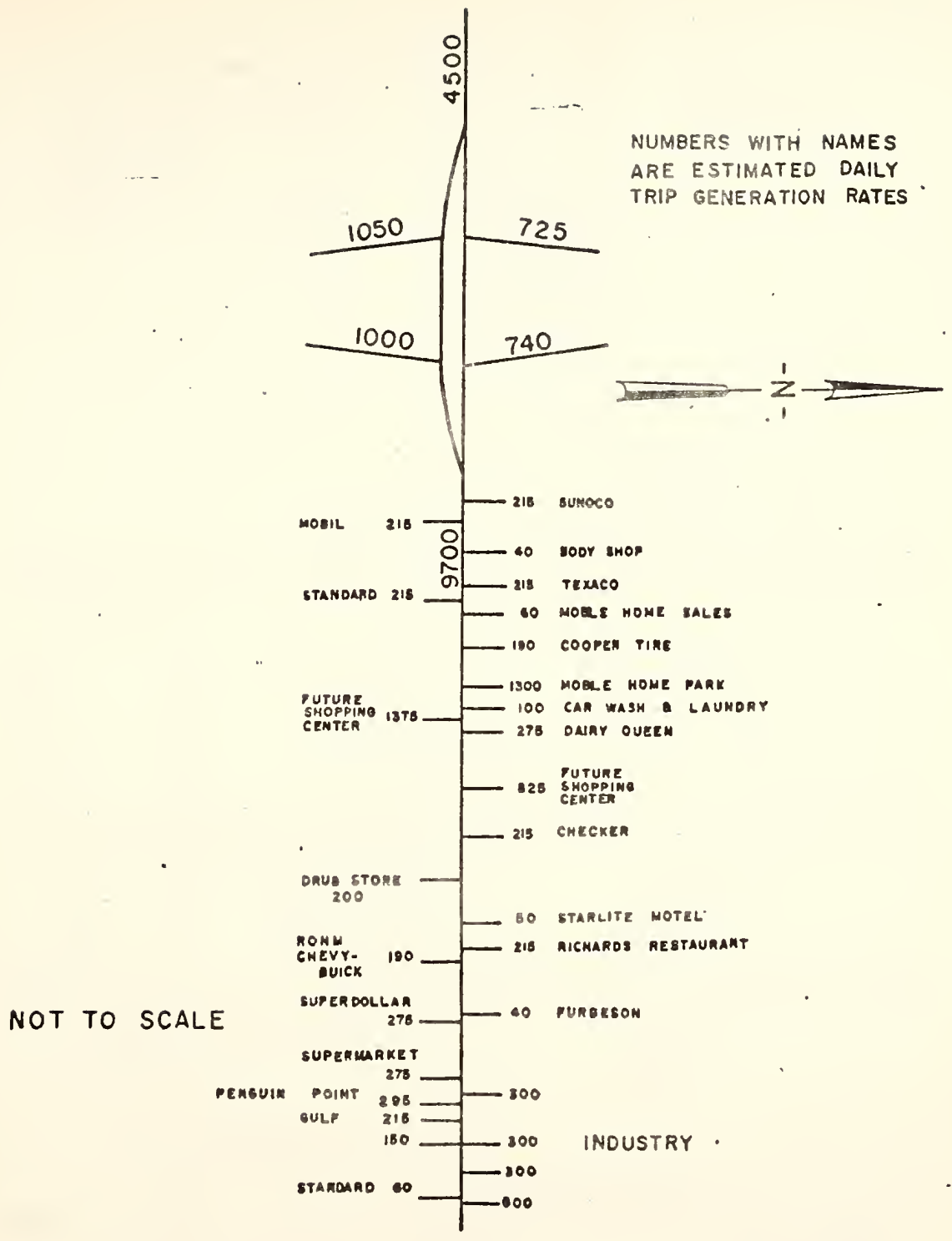

FIGURE 29. ESTIMATED DAILY TRIP GENERATION CHART FOR EXISTING $1-69$ \& SR 28 DEVELOPMENT 


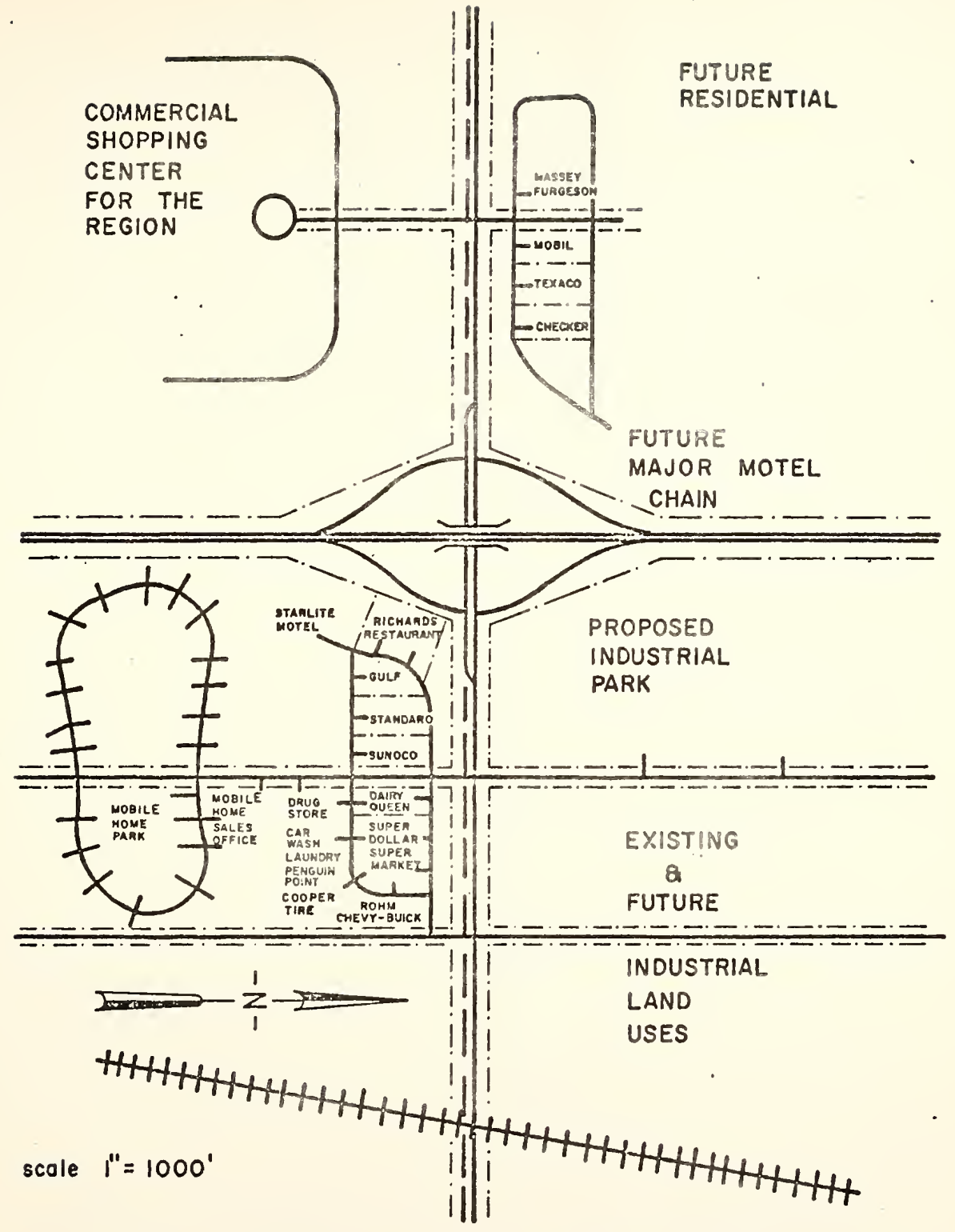

FIGURE 30. INTERCHANGE AREA PLAN ALTERNATIVE FOR $1-69$ \& SR 8 


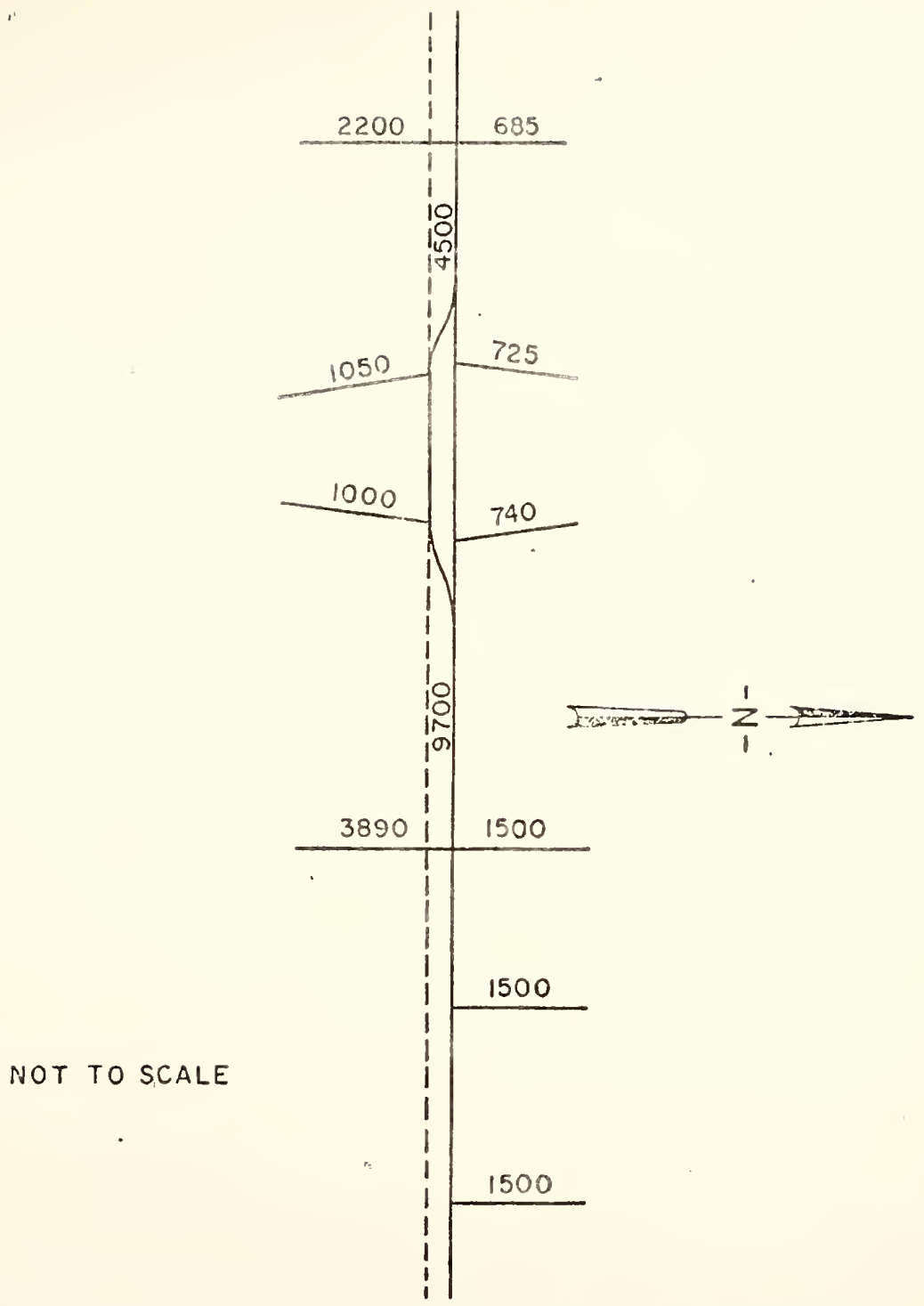

FIGURE 31. ESTIGATED DAILY TRIP GENERATION CHART FOR PLANNED $1-69$ \& S.R. 8 DEVELOPMENT 
The zonine scheme used as the base for all the procecting

diaxiams is but one example of hnw land uses can be compatibility arranced to serve interchance area's commity, private entemrise, and traffic flow requirements.

The crample of Case Nrea $V$ shows how all these controls might lead to beneficial comprehensive interchange area development.

The benefits such a suburban plan would offer are:

1. Optimum location of land use types as subjectively determined by timing development in the case studies.

2. Iand use compatibility.

3. Controlicd crossroute access points adequately spaced to provide selected but balanced use of crossroute intersections and to allow for favorable crossroute traffic signal control. progression should the future situation warrant such sicnals.

4. Adequate crossroute right of way (1201) to provide for a final crossroute crosssection concistine of a divided four lane roadway, with protected left tum bays in the median at crossroute intersection approaches, and with separate richt turm lanes as are appropriate at the different crossronte intersections. 


\section{CHAPTER VII}

\section{- sidMLAr AND CONCLUSion}

A general survey of land use development at interchanges was succossully condvcter at all rural and subjrban interchanges in January 1972. A more specific survey of land use change was conducted in July 1972 at suburban and urban interchanges. These two surveys are quantitatively summarized in Chapters 4 and 6 of this roport respectively. The following discussion presents descriptive factors which it is strongly believed led to or explain these earlier facts and figures.

\section{Road User Services}

Since the non-toll freeways offer no commercial services to the motorists within the right of way, interchances are prime targets for road user service developments which satisfy fuel, food, or lodging requirements. Of these the cesoline station is the service of greatest demand at freeway interchanges, These atations draw freeway drivers with acute fuel needs or with secondary fuel requirements conveniently fulfilled in conjunction with or in proximity to neimhboring eating and lodgine accommodations. Crossroute drivers with acute fuel needs or those attracted by the station's convenient location with respect to neighboring work, shoppins, residential, recreation, or other trip end purposes are possible added interchange travelers. With a potential market so much broader than the traditional neighborhood station, which depends heavily on repeat business, it is logical that fuel companies are very speculative and compctitivc in acquiring hishly accessible and hichly visible plots on virtually frec access crossroutes within interchanee areas.

In competition amone business establishments shortly after interchange opening, a multifunctional enterprise providing many 
diverse but compatible sempices, such cs, a truck-autownnt-?oreineservices-stop, overshadows ne neinhoring single function establishment in terms of busincss encrated. Hercver, lon reance crmected return for the single function establishments secms to overcide speculation risks inherent in the fact that the casoline business

A.though supplying firms have been operating, in many cases, for several decades there appears to be a remarkable lack of information in most firms on such itoms as operating thresholds, amount of income derived from various activities (for example, in service stations grs sales vS THA itcms), ete. that would enable them to estimate anounts that could realistically be paid for sites and the anount of land needed to support different levels of operation. (15)

Restaurants satisfying prepared food needs are limited in number reflecting the importance of adequate markets, of site advantages, of nejmhborins competition, and of supporting activities. Restaurants are operated in conjunction with automotive services, within neichborhood or rerional shoppins centers, within or near ovemight lodging facilities of all types, strong seasonal or all veathen recreational attractions, and large industrial complexes, or near hich density residential developments.

Food carry-outs, small counter and grill setups, and vending machine refreshment bars are businesses catering more to quick service requirements of through Interstate travelers, short term shoppers, or blue collar workers employed in the interchance area.

Large chain motels, small business motels, trailer nark and camping facilities are the three major lodging activities most likely to seek freeway interchange locations. The large chain motels seek the interchange for its first exposure to the freeway user, its convenience to ovemight travelers, its amenities to the convention businessman and short tem visitor that the downtown hotels with restricted parkine, more noise and congestion, and more crime cannot offer. A motel's location proximatc to interchange automotive, eating, and entcrtainment facilities is a desirable selline point. In fact, the latter two activities are often incorporater into the motel complex in the form of dining facilitics, night clubs, or sports rooms and areas. Although these chain motels often build up in staces, the initial structure is larce 
enough for their owners to be extecmoly concerncd about attracting a 80 sufficient number of travelers. Therefore, interchanges around the lareer citics, such as Fort layne, with a crosssection of tourists, businessmen, and overnicht-throurch-travelcrs as possible customers, are the most Iikely to attract the Holiday Inns and the Howard Johnoons.

Small business motels can afford to locate in the absence of reavy frceway travel exposure, of an urban influence, or of strong recreational pull in the form of state parks and lake resorts, provided onc of these is sufficiently strong enough to support economic survival. While less luxurious, these motels are generally. less costly and more likely to attract the vacationing family on a short overmight, or long weekly stay. Interchanges near switning, fishing, and huntine areas, as well as near cities below 10,000 population, or alone heavily traveled freevay corridors are likely development areas.

Among American families, camping or trailer facilities are becoming popular for vacationing. The monetary savings and fref dom of movement are prime factors in this erowth of user interest. Therefore, the park owmers must seek a location vith enough acreage, enough exposure to the traveler, and in proyimity to food supply and to family entertainment and recreation. The present optimum location for this blend of activities is logically near the interchance arcas.

\section{Open Space and Recreation}

Ofton associated with the three types of lodwing aforementioned are public and private recreational facilities. Public outaoor fecilities included in this group are state parks, lakes, golf courses, and wildlife preservas. The cause and effect of the transportation-development process is iterative in that the interchange location and desion was partially determined on the basis of present and projected major recreational opportunities in the surrounding landscane; then with the interchance completed there is a flood of public and nrivate leisure activity development which in turm requires uprraded desicm and capacity considerations on the crossroute, and so on with time. This dynamic transportation improvcment-land use development relationship 
with subscaunut interations promotes increased cconomic crowth of formerly inaccessible natura? lendscape.

Iess dependent on natural landscann but agrain looking for treveler exposure are land extensive private recreational facilities. Amusement parks, county fairs, bowling allcys, outdoor theaters, ploza cinemas, and other attractions all seek the volume, parl-in, land availability, and land accesibility that interchange areas offer.

\section{Residential Development}

Residential srowth, especially on the fringe of established communities is frcquently present along the freeway to utilize nearby interchances for ready access to established centers. Generally detached sinfle femily home subdivisions are the lancest in supply and demand in the residential market. Often the freeway makes it possible to commute twice the distance in a given time period as on a non access controlled highway facility. This has prompted people to allot a small time addition for the work trip in order to move out to more onen surroundings where home and land are more reasonably priced than in city subdivisions. Though neighborhood shopping conveniences and friendships may be missing at first, they should come as the area development progresses. $\Lambda$ number of suburban residential subdivisions will surely catalyze demand for supporting commercial, industrial, and recreational land vses.

The interchange areas are also excellent sites for the rrowing number of multifamily carden apartment and tomhouse compleyes. Land made available by the freeway and accessible by the interchanges can be planned for these hich density uses successfully. With home services, such as laundry facilities, complete utilities and appliances, and maintenance and repair furmished and with moderm social opportunities, such as nursery facilities, indoor and outdoor recreational areas, and entertainment rooms, not always found immediately in growing detached $v$ single family home subdivisions, provided as an integral part of the new apartment complexes, a full spectmum of livine necds for differcnt incomez within onc planned cnvironment can draw a, sizeable housing marlet in the nresent highly mobilc society. 


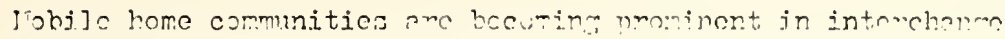
areas. The groving demand for cconomic lodwing in the face of incressed matcrial and lohor costs is slouly chanmine the imnec of mobile home commuties from hidden transiont substandned croupines to voll planned midile class communities for pormanont residents.

\section{Industrial Develonment}

The work trip, a need mentioned under multifemily residential types, becomes increasingly shorter for outlying residential districts as industry relocates on available acrease near improved transportation routes, near the labor force, and to the modem breals of bulk points while staying vithin areas served by needed utilities and preferably by a railroad. tholesale houses, manufacturing plents, and supporting truck terminals all find interchange areas convenient and economical locations. Land is less expensive than dormtorm land. Tme'r moving and delivering loca? goods can trevel farther, faster, and more economicn.Ily when teminals are locatcd near the freevay. Tand is available for adequate expansion especially for horizontal assembly line operations. And finally, freeway interchange areas offer excellent sites to coordinate land, air, and rail goods movements.

\section{Commercial Comnlcyes}

rith groods transfer already draving industrisl parks and wholnsale centors to interchanco losations, a funther minimization of production-distribution cost can result with retail chopsing centers located adjacent to the interchange. Employees for retail operations can reach work much easier. Neighborhood shopping centers and small individual retail stores are compliments to road user, residential, and industrial land uses discussed earlier. Advertising through extensive exposure is an important benefit of an adjacent freeway.

Pegional shopping centers, while enjoying the interchange benefits mentioned above in addition offer parkin and rodem mall comparative shopping opportunitics in a more relaxcd and lnnnor atmosphere than the 
prosent concosted, unconsolidated, and unn? nmot con rhonpins; opportunities.

All prececding sections sumarize the possibilitics for and the many existing activities of interchance area development by land use type. Each interchange may not have all the land use types discussed above but each interchange will reach its ecuilibrium levcl of land use interaction at some time after frecway construction. In an effort to develop a simplified measure of the level of development, the land use development model of Chapter $V$ was calibrated. The model as developed can be useful as a utility measure of all interchange development. Should the independent factors for a given interchange as projected ten years into the future yield a development magnitude of 15 as opposed to a development magnitude of 5 , it is safe to assume that priority for planning should be eiven "first" to the interchange whose projected ten year growth is 15. Hopefully, as a followup to pinpointing priority areas, "first" would mean that detailed planning and land use controls necessam to implement a plan, an examplc of which concludes Chapter Six, should be a part of planning the freeway location and interchange location. Fesultant land use control along the crossroute should insure the continued safety and efficiency of interchange desion components for the desion life of the vrece separated stmucture.

To briefly highlicht some major findines and conclusions of this report:

1. No interchange land use development model has been developed in sufficient detail to predict the extent of individual land use types in an interchange area to date.

2. Successful interchance area planning must recownize the intcrests of highway road uscrs, of busincsses, and of land use and highway planners in devisine the system of land use control least dismptive to existine preintexstate devclopment while yielding the best lone range benefits for all. 


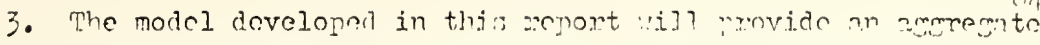
rank utility mearmus of prohable dovelonment at s. future date for ench rural interchange in Indiana. Avoilable planning funds can then be directed toward the interchances with a hich rank which upon more detailed examination lack adeourte comprehensive interchange land use planning.

4. Detailed comprehensive interchange land use planning should be based in a qualitative way on a similar type interchange or common aspects of different interchanges already well developed.

5. A dictionary of case suburban and urban fringe interchange studies for a qualitative reference in Indiana is initiated in Chapter six. Substantial compilation of similar dictionaries in neichboring states and of dictionary expansion within Indiana could provide the broad thta base required to prepare land use models of detailed land use types.

6. Aerial photographs must be taken at remlar intervals, for instance every year, to be of use in land use change analyses of interchange areas.

7. Driveway permit applications should be standarized with minimum requirements and a complete centralized data bank maintained at the State level.

8. Field survey would be easiest method to update development at interchanises already inventoried. Purchase and deed county records may be a more accurate and comnlete source (in studying changes in land uses) for the surburban and urban fxinge interchanges not yet inventoried.

9. Land use, design, and traffic controls must be combined into responsive and strong legal packaces to be effectively enforced and used as a foundation for comprehonsive interchange land use planning. 


\section{CHAPTPR VIII}

RECORTIDITIONS FOR FTRTHER RESEAPCH

1. The weighted dependent variable of the final model in Chapter Five could be further rofined by conducting a license plate surver of users of different land use types to determine local, crossroute, and Interstate destinations and to deternine total generation rates of different land use types.

2. A study through a search of sales records could substantiate weirgts developed from comparative land use traffic generation rates.

3. Further case studies of suburban interchanme areas compiled from detailed records of other states interchange arca development studies would be useful along with funther refinements in :eighting different land use types in building a useful mocel of surburban interchange land use development.

4. The sreater the data banl: of a subcatceory collected the more chance that changes and casual factors in the dynamic and speculative land use market can be quantitatively explained.

5. If driveway spacinrs, drivoway land use semed, roodvay crossscction; speeds, travel time and delay, accident experience, interchangre type, and volume of crossroute vere available, more definite relationships of land use development to related safety and congestion on the ramps and on the crossroute might be developed if added case study areas were inventoried in addition to those already initially explored in this report.

6. An entire study on the legal potential of usine new and innovative land ure controls in implementing comprehensive interchange land use devclonment planning satisfactory to local, state, and federal govemmental planning arencies certainly needs to be done by someone with an adcquate law beckground. 
BIBLIOGRAPHY 
BIBLIOGRAPIY

1. American Association of State Highray Officials, $\Lambda$ Policr on Ceometric Desim of Rural Himhways, (Iashinmton, D.C., 1966).

2. Ashley, Roy H. and Villiam F. Berard, "Interchange Development Along 180 Miles of I-94." ITinhwav Research Pecond, Volume 96 (Washington, D.C.: Highway Research Board of the Thational Academy of Sciences, 1965), $46-58$.

3. Dansereau, H. Yirr, A. Richard, and John R. Maiolo, "Specified Social Teteminants of Attitudes Torard Communjty Planninm and Zoning," Donn State Institute For Research on Land and Vator Resources, Research Repont Number 9, (1966).

4. Byer]y, Raymond :.., "Land Use and Iand Value in Frur Interchance Communitics - In Interim Report on the Yorl Study." Penn State Institute For Rerearch on Land and Vater Resources, Research Report number 7, (1.966).

5. Garrison, William I., "Iand Uses In The Vicinity of Freevay Interchances: liodels of Iand Use Developments and Related Traffic Flows." The Bureau of Public Roads U.S. Department of Commerce, (Nay 31, 1961).

6. High:vay Roscaxch Board, Hi whay Capacity Manunl: IIi whwar Resnarch Board Special Revort 87, (Vashinfton, D.C., Irational Academy of Sciences Mntionn? Research Council, 1966).

7. Horwood, Edwar I:., Charles Graves, and Clar1. D. Domers, "An Evaluation of Land - Use Control Procedurcs at Freevay Approcchos," Hi mhway Rescarch Boand Bulletin, Volume 288 (Vashington, D.C.: Highray Pesearch Board of the Tational Academy of Sciences, 1961), 67-82.

8. Indiana State Highway Commission, "The Traffic Interchange and Community Crowth."

9. Isibor, E.I., "Modeling The Impact of Highryy Improvements on the Value of Adjacent Land Parcols." Ph.D. thesis, Puxdue University, Joint Hiđhyay Research Project, Deccmber 1969.

10. Yuhn, Jerman A.J., "Planninr Implications of Jrben and. Palral Freevay Interchancer." Jouxmal of Urban Tlanmine and Devolonment Division, Volume 95 (Apri.l 1969), 81-??. 


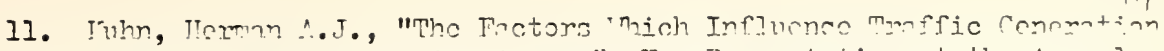
st Mral. Itimhroy Snryice Areas." lior Irosentation at the Annual

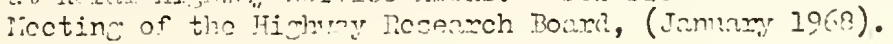

12. "Iand Use and Dovelopment -t Highway Interchanics: A Strmposium," Hirhway Research Board Iul Ietin, Volume 288 (Washinmton, D.C.: Hichway Research Poord of the National Academy of Sciences, 1961).

13. Iawrence, W.M.S. and Associates, Inc., "Interchange Area Planning: A Special Study For Lake County, Indiana," (January 1967).

14. Marble, Duane F., "Taer Services and the Tomand for Iand at Interchange Points." Highway Research Bcärd Bulletin, Volume 288 (Vashington, D.C.: Iilehway Research Board of the Tational Acadeny of Sciences, 1961), 25-31.

15. Mason, "Interchange Development and Land Use Controls,". ongoing study at University of Mlabana.

16. Michael, Harold I., Traffic Characteristics and Moasurements," class notes Purdue University CE 561, (Fall 1971).

17. Ohio Department of Highways, "Factors Influencing Iand DevelopmentSubdivision Development Study - Interstate 7l-Franklin County," (September 1970).

18. Ostle, Bemard, Statistics In Research, (Ames, Iowa, The Iowa State University Press, 1963).

19. Pendelton, William C., "An Empirical Study of Changes in Iand Use at Freevay Interchanges," Praffic Quarterly, Volume 19 (January 1965), 89-100.

20. Sauerlender, Oven H., Donaldson Jr., Robert B., and Richard D. Twark, "Factors That Influence Economic Develonment at Non-TIrban Interchange Locations," Penn State Institute for Research on Iand and Hater Resourccs, Research Report 9, (1966).

21. Spears, John D. and Charles F. Smith, A Stury of I nnd Devclonment and Utilization at Interchane Areas Adjacont To Interstate 10 in Tennessee (Inoxvilie, Tonnessee: University of Tonnessec, Iichiray Research Procram and U.S. Bureau of Public Roads, September, 1968).

22. State Highway Commission of Hisconsin, Interchanme Area Plannins in Visconsin (Madison, Visconsin: Planning and Rescarch Division, State Highway Commission of Wisconsin, undated).

23. Statistical Computer Library for Purdue University, BMDO2R Statistical Prosram, (1972). 
21. Thicl, Ployd I., "][i m]way Interchanre Anciz Development,"

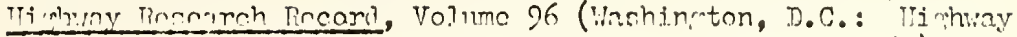
Jinscarch l3onrd of the Jational sealemy of Scicnces, 1965), $21-15$.

25. Utah State Depertment of Illohwys, Utah Inno Uas at Interchanere Study Instmictional Manual, (Salt Iake City, Utah: Utah State Departinent of Hirhyays and the U.S. Burcau of Public Roads, undatcd).

25. Vodrazka, Walter C., "Subclessification of The State Hirhway System of Indiana Bascd on Synthesis of Intercity Travel," (Joint Highway Rescarch Project, School of Civil Enrincoring, Furdue Unviersity, Lafayette, Indiana, February 15, 1968). 


\section{GINIRAL REFTRTNCTS}

1. Adkins, Villiam C., "Economic Impacts of Thepresswajs in Dallas and San Antonio," Praffic Duarterly, (July 1959), np. 333-345.

2. Bardwell and Ierry, "Measuring The Economic Impact of a IimitedAccess Highway on Communities, Iand Use and Land Value," Pighway Rescarch Board Bulletin, Volume 268 (Vashington, D.C.: Hichway . Research Board of the National Academ of Scicnces, 1960).

3. Barton- Ischman Associates, Inc., "Case Studies of Selected Interchange Mreas," Highwar and Innd Tse Relationchins in Interchance Areas, Supplementary Report Irumber 3, (Evanston, Illinois, November 1963).

4. Barton- Aschman Associates, Inc., "Commtor Parking at Highway Interchanges," (Chicago, Washington, D.C., and Minneapolis-St. Paul, Piarch 1970).

5. Barton- Aschman Associates, Inc., "Current Laws and Practices Affecting Interchange Area Planning," Hinhway and Tand Tse Relationships in Interchanre Areas, Supplementary report Tumber I, (Evanston, Illinois, Hovember 1963).

6. Barton- Aschman Associates, Inc., Hiphwar and Land Use Relationshins in Interchence Areas, Supplementem Report Number 2, (Evenston, Illinois, November 1963).

7. Brand, Daniel, Brian Barber, and Michael Jacobs, "Techninue for Relating Transportation Improvements and Trban Develonment Patterns," Hichway Research Record, Volume 207 ("lashinston, D.C.: Highway Research Board of the National Academy of Sciences, 1967), pp. 53-67.

8. Chapin, F. Stuart, Jr., "A Model for Simulating Residential Development," AIP Joumal, (ITay 1965), pp. 120-125.

9. Coyle, John J., H. Kirk Dansereau, John C. Frey, and Robert D. Pashel, "Interchange Protection an' Community Structure," IIi Jhway Research Record, Volume 75 (Vashincton, D.C.: Highway Research Board of the Irational Acadomy of Sciences, 1965), pp. 62-74. 
10. Tnnscrcau, IT. Mirle, Jolun C. Trey, and Robert D. Pashek, IIirhway Dovelopment: Commuity $\Lambda$ ttitudes and Ormnization," IIimhny

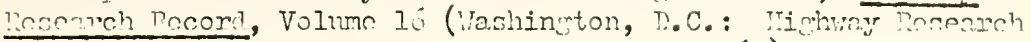
Roarl of the liational icaremy of Sciences, 1963), pp. 14-59.

11. Draper and Smith, Apnlicd Ropression Analysis, (Iow York, John niey \& Sons, Inc., 1966).

12. Mlis, Raymond H., Modelinm of Houschold Location: A Statistical Approach," IIi linar Reserrch Record, Volume 207 (Vkahington, D.C., Hi whway Research Board of the Iational Acadcry of Sciences, 1967). PD. A.2-52.

13. Flaherty, Iark C., "Comercial Ilichway Service Districts and the Interstate," Himhwy Research Record, Volume 96 (Washington, D.C., Highway Research Doard of tho Iational Academy of Sciences, 1965), pp. 8-18.

14. Fronloland, "Iand Uze Controls at Freeway Interchances in California," Troffic vorterly, (October 1965), pp. 51]-555.

15. Frey, J.C., Dansereau, Pashek, and Twart, "Land-Use Planning and the Interchange Community," Hi.rhwar Rescarch Board Bulletin, Volume 327 (?ashington, D.C., Hichnay Mesenmch Boand of the ITational Academy of Sciences, 1962), pp. 56-66.

16. Gom, Richard C. and. Iarvey R. Joyner, "Cross Route Access Desicm in Interchange Áreas," Barton Aschman Associates, Inc., (undater).

17. Greenbie, Barrie Barstow, "Interchançe Planning in a Rural Area," Traffic nuanterly, (April 1970), np. 265-277.

18. M.O.P. Committee of Ohio, "Interchange Aros Dovclopment: Y Narks The Spot," (undated).

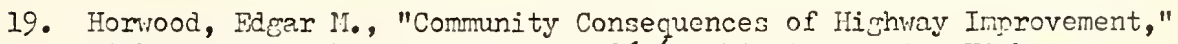
Himhry Tesearch Record, Volume 96 (Washington, D.C., Highray Research Board of the IVational Academy of Scionces, 1965), pp. 1-7.

20. Yirk, H. T., "County Guide for Growth: $A B$ Zoning at Interchance quadrants 1967-1987," unpublished paper, (Purduc University, April 1967).

21. Iathrop, George T. and John R. Hambures, "An Opportunity Accessibility Hodel For Allocatine Recional Growth," AIP Journal, (May 1965), pp. 45-103.

22. Iovin, D. R., "The Highway Interchanre Iand-Use Problem," Hi,rhway Pesearch Board Bulletin, Volume 288 (Washintton, D. C., Ii chn:ay Research Board of the National Academy of Sciences, 1961), pp. 1-24. 
2:. Neve, James P., Jx., "A Scorcboard for Interchrnmer," Tmefic Thrincorins, Volume 32, Tumber 12, (Neptomber 1962), nр. 2?,23,35.

24. Pondelton, Villian C., "Land Use at Frocway Interchenres," Traffic Cuarterly, (Octobcr 1961), pp. 535-516.

25. Fennaylvania State University, "BIairsville: A Bypass Study," (Univcrsity Park, Pennsylvania, 1962).

26. Sawhill, R.B., Ebner. J.H., "Freeways and Residential Neighborhoods," Himhay Research Pocord, Volume 119 (Vashington, D.C., Hi ghway Rosearch Board of the Thtional Acadomy of Sciences, 1966), p. 57.

27. Schlager, Kenneth J., "A Land Use Plan Dcsien Model," AIP Joumal, (May 1965), pp. 103-111.

28. Schlarger, Kenneth J., "A Recursive Programmine Theory of the Residential Land Development Process, Himhray Reseanch Record, Tolume 126, (vashington, D.C., Hichway Research Board of the National Mcademy of Sciences, 1966), pp. 24-31.

29. Stanhagen, Villiam H., "Ili whway Interchange and Land-Use Controls," IIichway Rescarch Board Bulletin, Volume 288, (Washington, D.C., Fighway Rescarch Board of the Tational Academy of Sciences, 1961), p. 32-60.

30. Stuart, D.G., "Multiple-Purpose Freeway Land Devclopment," Himhway Rescarch Board Bulletin, Volume 217 (Vashincton, D.C., Hi.ghway Research Board of the Tational Academy of Sciences, 1959), pp. 1-8.

31. Sverdloff, Carl I. and Joseph R. Stovers, " $\Lambda$ Test of Some First Generation Residential Iand Use Models," Hirhway Research Record, Volume 126 (Vashington, ].C., IIighway Dosearch Board of the IIatinnal Academy of Sciences, 1966), Pp. 38-59.

32. Utah State Department of Hirhrays, "Utah: Iand Use Control Iethods For Interchance Areas," Junc 1957.

33. Walsh, Stuart Parmy, "Some Tffects of Limited Access Himhays on Adjacent Iand Use," Himhwry Pesearch Bosrd Bulletin, Volume 227 (Washington, D.C., High!ry Research Boand of the National Academy of Sciences, 1959(, pp. 78-82.

34. Vilson, "Caze Studies of Effects of Roacs on Development," II mhw Research Record, Volume 115, ('iashinrton, D.C., Hishway Research Board of the National Academy of Sciences, 1966), pp. 10-18.

35. Hitenstein, M., " $\Lambda$ Report on $\Lambda p p l i c a t i o n$ of $\Lambda$ erial Photo vraphy to Truan Innd Use Inventory, Mnalysis, and Plonning, Dhnto Fonminenninm, Volume 22, (1956), pp. 656-663. 
APPENDICES 
APPFIDIX A

DFFINITIONS 
T3A - An abbreviation for Tircs, Battcrics, and "cocosories

Artcrial Timhng - "1 hinhvay nrimarily for thrown troffic, uswally

on $=$ continuous route" (7)

Ihoressway - "A divided arterial himhwy for throumh traffic with full or partial control of access and generally with grade separations at major intersections" (7)

Freevay - " $\Lambda$ n expressway with fuII control of access" (7)

Frontage Road - " $\Lambda$ road contiguous to an generally paralleling an expressway, freevay, parkway, or through street and so described as to intercept, collect, and distribute traffic desiring to cross, enter, or leave such highway and which may fumish access to property that othervise would be isolated as a result of the controlled-access feature; sometimes called a service road." (7)

Auxiliary Iane - "The portion of roadway adjoining the traveled way for pariinr, speed change, or for other purposes supplementary to the through traffic movement." (7)

Ramp Terminal - "The general area where a ramp connects with a roadway. Ramps have both entrance and exit terminals. The entrance terminal relates to a merging condition, the exit terminal relates to a diverging condition." (7)

Capacity - "Canacity is the maximum number of vehicles which has a reasonable expectation of passing over a given section of a lane or a roadway in one direction (or in both directions for a two-lane or a three-lane highvay) during a given time pcriod under prevailing roadway and traffic conditions." (7)

Level of Service - "Level of service is a number of factors, which include speed and travel time, traffic interruptions, freedom to maneuver, safety, drivine comfort, and convenience, and operating costs." (7)

These definitions thus far are as given in the Jighway Capacity Manual's Chapter Two (7). Other terms used less frequently in this paper, such as, Control of Access, Crosssection components, Cross-rectional Desien, Traffic Iane, Intersection, Channelization, Traffic Control Devices, PeakIlour Traffic, Bottleneck, and subclassifications of these tcrms are also 
used os defincd in Chapter two of the Ifighny Cayacity finnul (7). Interchanme Design- Niamone, cloverlenf, partiol cloverleof, and directional interchanges arc terms used in this renort as defincd and illustrated in "A Policy on Geometric Design of Irural IIichways" 1965, Chapter IX (1).

UNITS OF DEVELOPR:TMNT

Truck Stop - A casoline business which semes tructs and untomobiles, has a cafeteria, and has minimal ovemicht bedding for truck drivers.

Motel-

Large Chain Motel - $\mathrm{ny}$ motol with a minimus of 40 rental units and with a dining room.

Small Business Motel - Any motel with a maximum of 110 rental units. Restaurant - Any eating business establishment having a minimuri of twenty seats.

Recreation Park - An amusement park.

Trailer Park - An area capable of accomodating five or more overmight camper trailers.

Mobile Home Sales - A business dealing in sales of mobile home trailers. Public Facilities - A golf course, lake, or a similar public recreation area.

Food Service - A carry-out food business with at leest 10 paring spaces provided.

Small Local Business - A sincle store dealing in sales of retail merchandise. Service Station - A casoline busincss vith a minimum of two islands carable of serving at least four automobiles at one time. These stations usually have a snack bar with food self-service vending machines or a smell short order grill to scrve the traveler quickly.

Industry (Or Regional Office) - Any industrial business covering an area of at loast one acre and at most ten acres.

Neighborhood Shopping Center - Any shoppin center composed of at lcast one supermarket and one major department store. 
Low Jensity Residentis? - Any subelirisinn of ten th turnty dyolline unjts with on rvemee individurl lnt refee of more than one acre.

Jedium Ionsity Rosicential Subdivision - Any resicentiat subdivisinn mrenter than twenty units and less than eimhty units with averagc individuol lot sizes less than one acre.

ERucational - Lny level school.

Recrional Shopping Center - $\Lambda$ ny shopping center with two or more department stores.

Rural Interchange - 111 interchnnes not clasciried as bejng Suburban or Urban Pringe Interchanges.

Surburben Interchance - Any jnterchange vith at least 8 units of dovelopment and within four miles of a city center whose 1970 Census Population is greater than 8000 or vithin seven miles of a city whose 1970 Census Population is meater than 70000 or within ten miles of a city center whnse 1970 Census Population is greater than 400000 .

Irban Fringe Interchange - Any interchance vith at lenst 15 units of development and vithin four miles of a city center whose 1970 Census Population is sreator than 70000 . 
APPINDIX B

INVENTIORY FORMS AND NUESTIONNAIRES 
IITURCIUNGR IDEDTITY

\begin{tabular}{|c|c|c|c|}
\hline $\begin{array}{l}\text { IITIRRSTATE } \\
\text { INTTERCHUIGT }\end{array}$ & $\begin{array}{c}\text { INTERSTATE } \\
\text { ROUTE }\end{array}$ & CROSSROUTR & $\begin{array}{c}\text { INTTRCHANGS } \\
\text { TYTE }\end{array}$ \\
\hline & & & \\
\hline
\end{tabular}

$\therefore$

PLOT INFORMATION

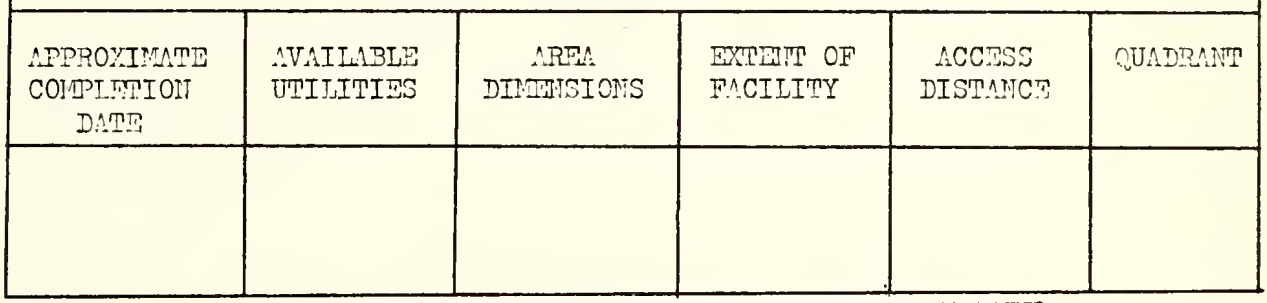

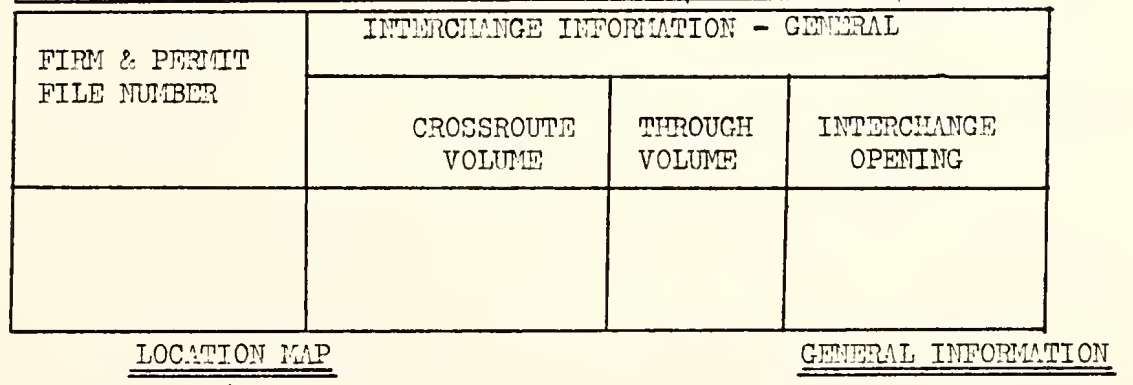

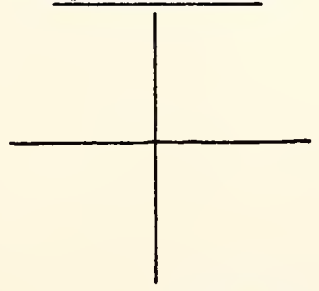

FIGURE BI. DATA SHETI FOR FIJUD SURVEY 
Murdue University

Civil Ponineerin? RId,

V. Irafayette, Indiana 47907

Dear Sir:

I am presently conducting a study of. Interstate Interchange Areas and Development in Indjana. The pumposc of this work is to enable highway planners and designers to plan future interchanges for development most Iikely to occur at such intcrchanges and for development in a locational pattern most adrontareous to all concerned. Principally, busincss owners both before and after the Interstate opening, highways' travelers, and highway engineers will be the beneficiaries of improved planning for irterrated and complimentary use of interchange lands.

To be worthwile, any recommendations for the future should be realistically based on the prescnt demand for and on the present use of land. It is with this baclemround that I cone to you for one important data item in reconstructing the scquence of development around the present interchanges. This item is when to the best of vour knowlcdre did the establishment you own and /or operate first open for business.

Since this information is most vital to this study and so to the completion of my master's demee promram at Purdue, I would be most mateful if you would fill in and mail the attached nrestamned form as soon as possible.

With Sincere thanks,

Iawrence P. Fabbroni

Graduate Assistant

in Research 
When to the best of your knowledge did the establishment you orm and/or operate first open for business?

Tonth

Year

Iny added criticisms you might have about the highway or neighboring development are velcome. 
$\triangle P P E N D I X \quad C$

INTIRTOTY COJITG PROCEDURES 
S.nrd Tiumber( $($ ) (Co]umn .1-2)

0.1.

032055

$07,08,09,10,11,12$

$15,16,17,18,19,20$

$23,24,25,26$

$27,28,29,30$

$31,32,33,34$

41

43

$51,61,71,81$,

$52,62,72,82$

$53,63,73,83$,

$54,64,74,84$
Doncription

98

Ramn Volumns

Crossroute Volumes \& Dates

Parallel Route Volumes

Parallel Route'c Distances From

Interstate Interchanges

1950 Urban Center Populations

1960 Urban Center Populations

1970 Urban Conter Populations

Interchange Opening Date

Interchange Road User Develonment \& Date

Interstate Mileage To Travel To Urban

Center By Minimum Time Path

Thro-Iane Rural Mileage To Travel To Urban Center Sy Minimum Time Path

Multi-Lane High:ray Mi? leace To Travel To Urban Center By Iinimum Time Path Urban Highway Mileare To Travel To Urban Center By Minimum Time Path 


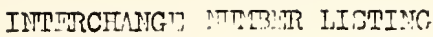

\begin{tabular}{|c|c|c|c|}
\hline Interchange & Core & Interchane & Core \\
\hline$I-658 \mathrm{US} 30$ & 0113 & I-718:Acton Road & 4748 \\
\hline$I-658: S R 8$ & 0114 & I-719.Pleasant Viev & 5401 \\
\hline$I-658: S R 2$ & 0115 & I-74riLondon Road & 5402 \\
\hline$I-658: S R 10$ & 1401 & I-74.Fairfield(S-1054) & 5403 \\
\hline$I-658$ SRII4 & 1402 & $I-7 \wedge$ \&SR9 & 5404 \\
\hline$I-658: 05231$ & 1403 & $I-719 \cdot S R A \Lambda$ & 5105 \\
\hline I-65\&US24 & 1404 & $I-74 \&$ SR244:: & 5407 \\
\hline I-65\&US52 & 4002 & I-748:SRI89(Midaletow) & 5301 \\
\hline$I-65 * S R 32$ & 4003 & $I-74 \& U S 421$ & 6501 \\
\hline$I-658: S R 39$ & 4004 & I-74\&SR 3 & 6502 \\
\hline$I-65 \& U S 52$ & 4005 & I-718iRossburg & 6503 \\
\hline I-652:SR267 & 4006 & I-712:SR?29 & 6601 \\
\hline I-65: S.SP334 & 4007 & I-7AGSRIOI & 6801 \\
\hline$I-748: 3 P 63$ & 4301 & $I-712: S R I$ & 6702 \\
\hline I-748:Stringtown Road & 4201 & I-748US52 & 6701 \\
\hline $\mathrm{I}-748 \mathrm{US} 4 \mathrm{I}$ & 4202 & I-708:Post Road & 4746 \\
\hline$I-71 \& S R 25$ & 4101 & I-708wount Comfort & 4.801 \\
\hline$I-748=U S 231$ & 4102 & $I-70 \& S R 9$ & 4802 \\
\hline$I-74 \& S R 32$ & 4103 & I-702:3RI09 & $4: 01$ \\
\hline$I-748 . S R 75$ & 4010 & $I-702=5 R 3$ & 49,02 \\
\hline$I-74 r E S R 39$ & 4601 & I-70\&New Lisbon & 4903 \\
\hline I-74\&Pittsboro & 4602 & I-70\&SPI & 5001 \\
\hline I-74\&SR267 & 4603 & I-70\&Centervilie (S-168) & 5002 \\
\hline I-70RUS40 & 5901 & $I-70 \& U S 35$ & 5003 \\
\hline I-70\&Damin Road & 5902 & $I-70 \varepsilon: U S 27$ & 5004 \\
\hline I-70\&US4I & 5903 & I-70\&SR227 & 5005 \\
\hline$I-702=S R 46$ & 5904 & I-708US40 & 5006 \\
\hline I-70\&SR59 & 5801 & $I-698: S R 38$ & 3703 \\
\hline I-702:SR243 & 4501 & I-6928SR9 & 3702 \\
\hline$I-70 \& U S 23 I$ & 4502 & I-698.SRI09 & 3701 \\
\hline I-70sLittle Point & 5601 & I-692:SR6? & 3604 \\
\hline$I-708$ SR39 & 1604 & I-698:SRI28 & 3602 \\
\hline$I-70 \& S R 267$ & 4605 & I-692:US35 & 3601 \\
\hline$I-65 \& U S 3 I$ & 5401 & $I-69 \& S R 26$ & 3203 \\
\hline$I-65 \& S R 46$ & 6402 & I-698SR22 & 3202 \\
\hline$I-652: S R 58$ & 6403 & $I-698=S R 18$ & 3201 \\
\hline I-658:US3IA & 7001 & $I-6985 R 218$ & 2103 \\
\hline$I-652 . S R 50$ & 7002 & $I-698: S R 5$ & 2102 \\
\hline$I-658$ SR250 & 7003 & $I-692: U S 224$ & 2101 \\
\hline$I-65 \&$ SR 256 & 7004 & I-698Lafayette Center Rd. & 1807 \\
\hline$I-652 . S R 56$ & 8001 & $I-692: U 524$ & 1806 \\
\hline I-652:NR160 & 8002 & I-692:SRI4 & 1805 \\
\hline I-652:3R698(Memphis) & 8101 & $I-692 . \operatorname{TIS3n}$ & 3804 \\
\hline I-6580S31:: & 8102 & $I-692: 5 R 3$ & 1803 \\
\hline$I-6525 R 60$ & 8403 & $I-698: 52327$ & 1802 \\
\hline I-652:US131 & 84.04 & I-692:3RI & 1801 \\
\hline I-712aPost Road & 4745 & I-698.Co. Rd. 111 & 0804 \\
\hline
\end{tabular}




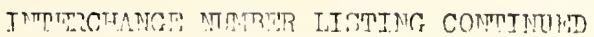

\begin{tabular}{|c|c|}
\hline Intcrchange & Corle \\
\hline$I-698=5 R 8$ & 0803 \\
\hline$I-69 i \mathrm{UD} 6$ & $080 ?$ \\
\hline $\mathrm{I}-60 \mathrm{~g} \mathrm{SR}$. & 0807 \\
\hline I-698US20 & 0706 \\
\hline$I-692: 2: 2590$ & 0705 \\
\hline I-602:31R727 & 0704 \\
\hline I-GOPSRRTO & 0703 \\
\hline I-698UIS27 & 070 \\
\hline
\end{tabular}


URBAN CENTER INDINTIFICATION

\begin{tabular}{|c|c|c|c|c|c|}
\hline \multicolumn{2}{|c|}{$\begin{array}{c}\text { Interstate } \\
\text { Route }\end{array}$} & I-70East & I-70:lest & I-71!iest & I-74Fast \\
\hline \multirow{15}{*}{$\begin{array}{l}\text { Urban } \\
\text { Center }\end{array}$} & 1 & Indianapolis & Indianapolis & Danville, Ill. & Indianapolis \\
\hline & 2 & Greenfield & Plainfield & Covington & Shelbyville \\
\hline & 3 & Carthage & Mooresville & Veedersburg & Rurshville \\
\hline & 4 & Shirley. & Danville & Attica & Greensburr \\
\hline & 5 & New Castle & Spencer & Waynes town & Batesvilie \\
\hline & 6 & Spiceland & Greencastle & Crawfordsvil]e & Brookville \\
\hline & 7 & $\begin{array}{l}\text { Mooreland } \\
\text { Dublin }\end{array}$ & Rrazil & Ladoģa & Lawrenceburg \\
\hline & 8 & $\begin{array}{l}\text { Mt. Auburm } \\
\text { Cambridge }\end{array}$ & Terre Haute & Jamestorn & $\begin{array}{l}\text { Cincinnati } \\
\text { Mrea }\end{array}$ \\
\hline & 9 & Milton & Vincennes & Lebanon & \\
\hline & 10 & Hagerstown & $\begin{array}{l}\text { W. Terre } \\
\text { Haute }\end{array}$ & Brownsburg & \\
\hline & 11 & Rushville & Rockville & Danville, Ind. & \\
\hline & 12 & Centerville & & Indianapolis & \\
\hline & 13 & Richmond & & & \\
\hline & 14 & Connersville & & & \\
\hline & 15 & Lynn & & & \\
\hline
\end{tabular}


URBAN CENTER IDNNTIFICATION

Interstate I-65 North I-65 South I-69 North Route

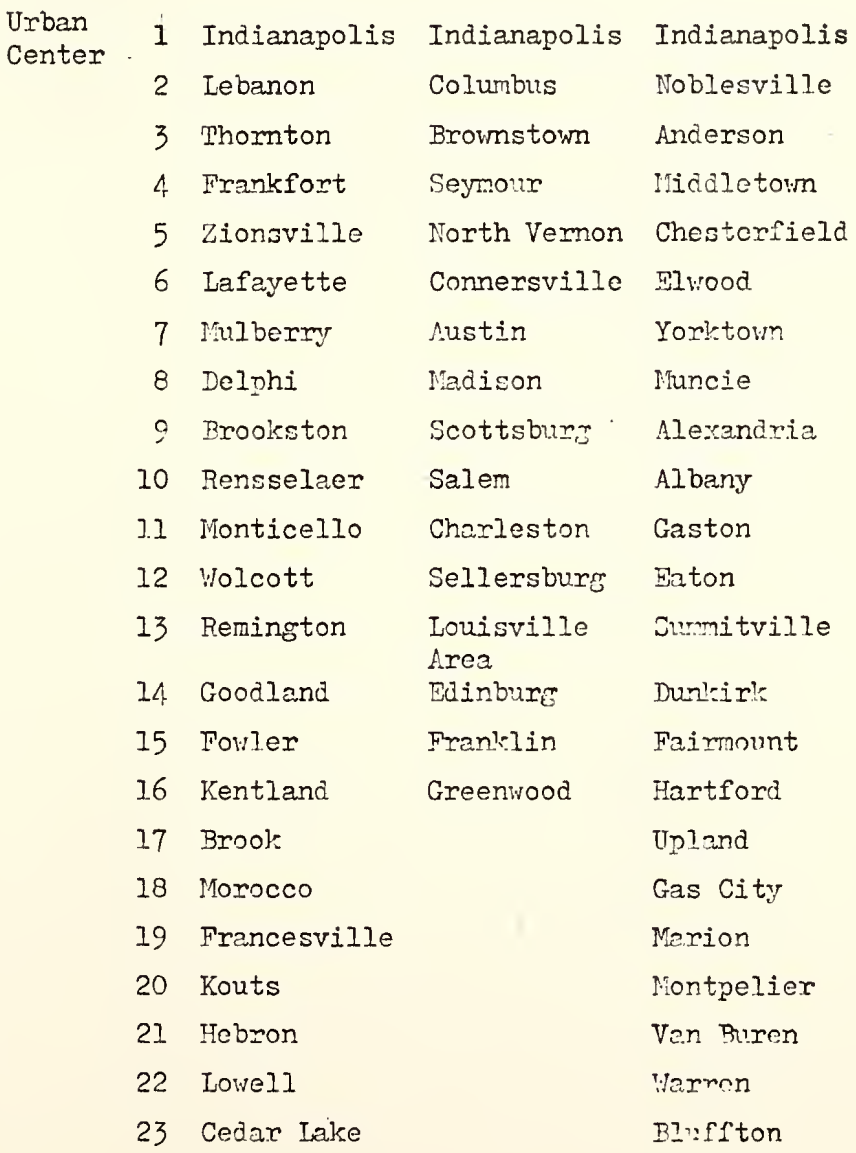


URBAN CLNRTR IDENTIFICATION

\begin{tabular}{|c|c|c|c|}
\hline \multicolumn{2}{|c|}{$\begin{array}{c}\text { Interstate } \\
\text { Route }\end{array}$} & I-65 North & I-69 North \\
\hline \multirow{2}{*}{$\begin{array}{l}\text { Urban } \\
\text { Center }\end{array}$} & 24 & Crown Point & Huntington \\
\hline & 25 & Valparaiso & Markle \\
\hline & 26 & Gary Area & Ossian \\
\hline & 27 & Monon & Decatur \\
\hline & 28 & & Roanolce \\
\hline & 29 & & Fort Wayne \\
\hline & 30 & & Columbian City \\
\hline & 31 & & Churubusco \\
\hline & 32 & & Garrett \\
\hline & 33 & & Auburn \\
\hline & 34 & & Avila \\
\hline & 35 & & albion \\
\hline & 36 & & Kendalville \\
\hline & 37 & & Lagrange \\
\hline & 38 & & Waterloo \\
\hline & 39 & & Butler \\
\hline & 40 & & Angola \\
\hline & 11 & & Fremont \\
\hline
\end{tabular}


ROUTR NTIBER IISTING

\begin{tabular}{|c|c|c|c|}
\hline CODE & ROUTE & CODE & ROUTE \\
\hline 0010 & SR 1 & 0480 & SR 48 \\
\hline 0020 & SR 2 & $0 / 90$ & SR 19 \\
\hline 0030 & SR 3 & 0520 & US 52 \\
\hline 0090 & SR 9 & 0530 & SR 53 \\
\hline 0270 & US 27 & 0550 & SR 55 \\
\hline 0310 & US 31 & 0620 & SR 62 \\
\hline 0311 & US $31 \mathrm{~A}$ & 0670 & SR 67 \\
\hline 0312 & US $31 \mathrm{I}$ & 1350 & SR 135 \\
\hline 0320 & SR 32 & 1360 & US 136 \\
\hline 0360 & US 36 & 2210 & SR 221 \\
\hline 0370 & SR 37 & 2310 & US 231 \\
\hline 0380 & SR 38 & 2340 & SR 234 \\
\hline $0 / 00$ & US 40 & 2360 & SR 236 \\
\hline 0410 & US 41 & 3030 & SR 303 \\
\hline 0420 & SR 12 & 3270 & SR 327 \\
\hline 0440 & SR 44 & 4210 & US 421 \\
\hline 0460 & SR 16 & & \\
\hline
\end{tabular}


CARD Ol Ramp Volumes

\begin{tabular}{|c|c|}
\hline COLUTN! (S) & DESCRIPTION \\
\hline $1-2$ & Ramp Volumes Card \\
\hline $3-6$ & See Interchance Number Iisting \\
\hline $7-11$ & Average Ramp Volume off ( $\Lambda \mathrm{DT}$ ) \\
\hline $12-16$ & Average Ramp Volume on $(\Lambda \amalg \mathrm{N})$ \\
\hline $17-20$ & Year of Volume Counts \\
\hline $21-25$ & Average Ramp Volume off ( $\Lambda \mathrm{DT})$ \\
\hline $26-30$ & Average Ramp Volunc on (ADY) \\
\hline $31-34$ & Year of Volume Counts \\
\hline $35-39$ & Averase Ramp Volume off (iNT) \\
\hline $40-44$ & Averagro Ramp Volume on (ADT) \\
\hline $45-18$ & Year of Volume Counts \\
\hline $49-53$ & Average Ramp Volume off (ADM) \\
\hline $54-58$ & Average Ramp Volume on ( $(\mathrm{DT})$ \\
\hline $59-62$ & Year of Volume Counts \\
\hline
\end{tabular}


CARD 03 Crossroute Volumes

\begin{tabular}{|c|c|c|}
\hline COLUT:IS(S) & CODE & DESCRIPTION \\
\hline $1-2$ & 03 & Crossroute Volume Card \\
\hline $3-6$ & See Interch & hance Number Listine \\
\hline $7-11$ & Crossroute & $\begin{array}{r}\text { Volume To One Side of Interstate } \\
\text { ( } A D T)\end{array}$ \\
\hline $12-16$ & Crossroute & Volume To Other Side of Interstate \\
\hline $17-21$ & Crossroute & $\begin{array}{c}\text { Volume To One Side of Interstate } \\
\text { (ADN) }\end{array}$ \\
\hline $22-26$ & Crossroute & $\begin{array}{l}\text { Volume To other Side of Interstate } \\
\text { (ADT) }\end{array}$ \\
\hline $27-31$ & Crossroute & $\begin{array}{l}\text { Volume To one Side of Interstate } \\
\text { (IDT) }\end{array}$ \\
\hline $32-36$ & Crossroute & Volume To Other Side of Interstate \\
\hline $37-41$ & Crossroute & $\begin{array}{l}\text { Volume To One Side of Interstate } \\
\text { (IDT) }\end{array}$ \\
\hline $42-46$ & Crossroute & $\begin{array}{r}\text { Volume To other Side of Interstate } \\
\text { (ADT) }\end{array}$ \\
\hline $47-51$ & Crossroute & $\begin{array}{l}\text { Volume To One Side of Interstate } \\
\text { (INT) }\end{array}$ \\
\hline $52-56$ & Crossroute & Volume To Other Side of Interstate \\
\hline $57-61$ & Crossroute & $\begin{array}{l}\text { Volume To One Side of Interstate } \\
\text { (IDT) }\end{array}$ \\
\hline $62-66$ & Crossroute & $\begin{array}{l}\text { Volume ro other Side of Interstate } \\
\text { (ADT) }\end{array}$ \\
\hline $67-71$ & Crossroute & $\begin{array}{l}\text { Volume To One Side of Interstate } \\
\text { (ADT) }\end{array}$ \\
\hline $72-76$ & Crossroute & $\begin{array}{l}\text { Volume To Other Side of Interstate } \\
\text { ( } \triangle D T \text { ) }\end{array}$ \\
\hline
\end{tabular}


CARD 05 Year of Crossroute Volume Count

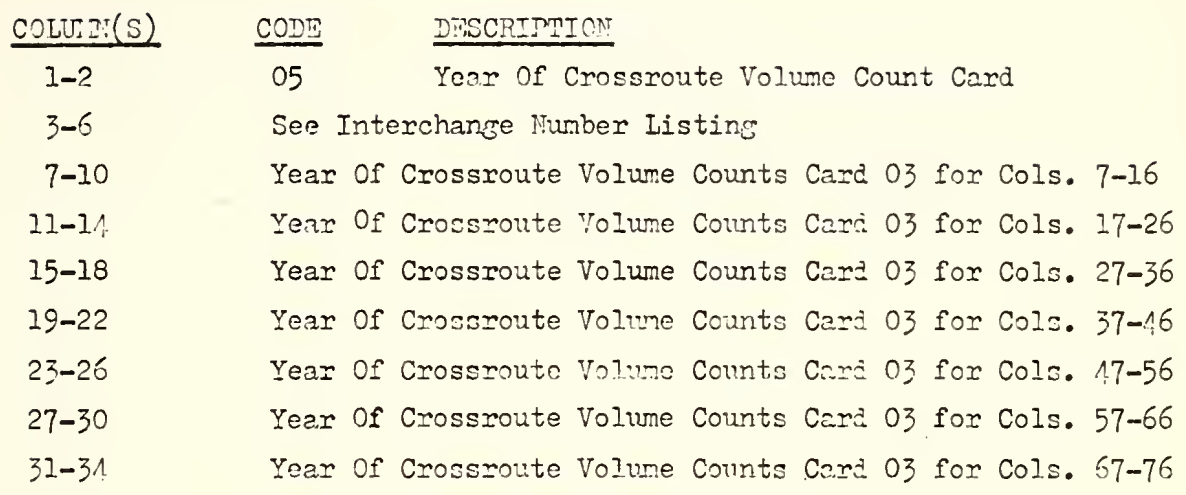


CAPDS 07,08,09,10,11,12 Parallel Route Volumes

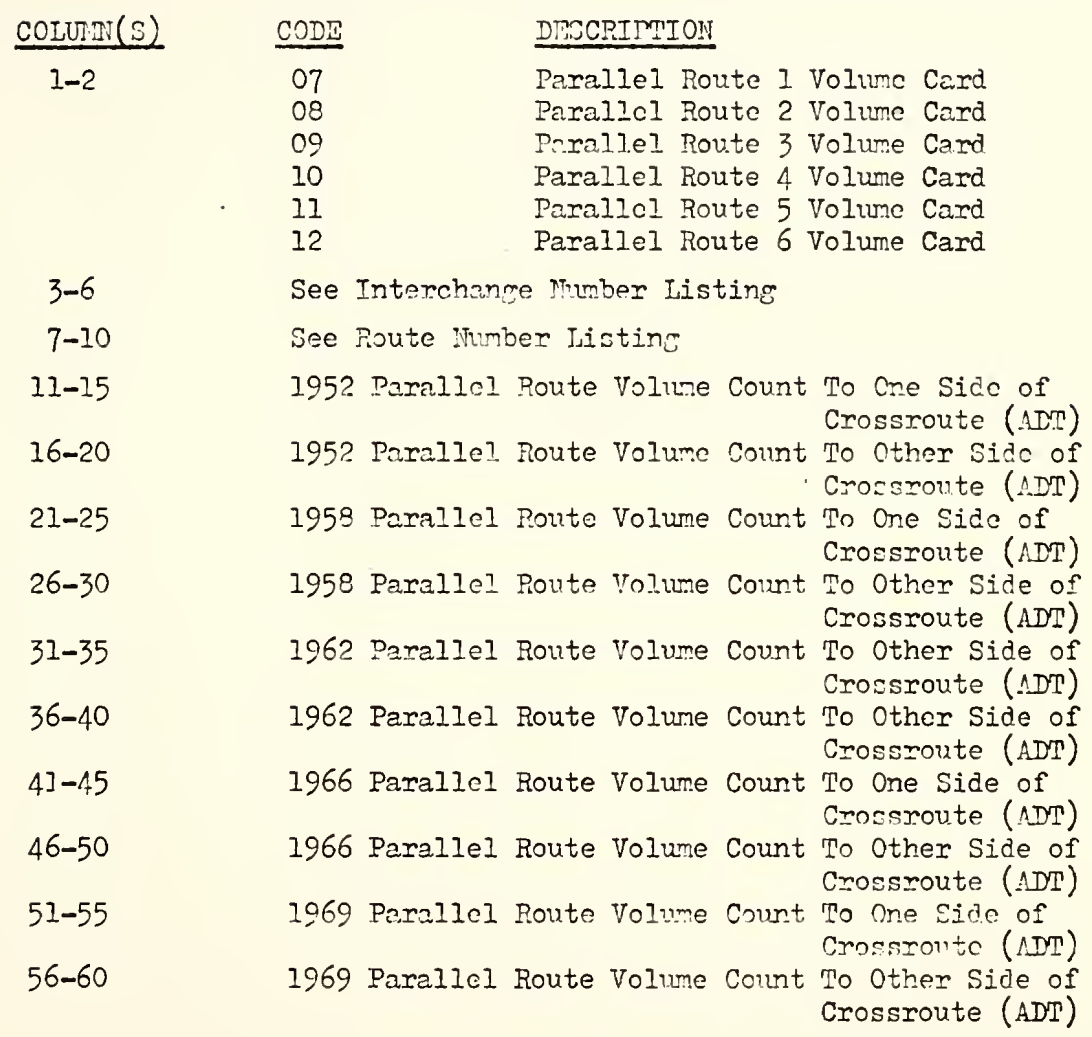




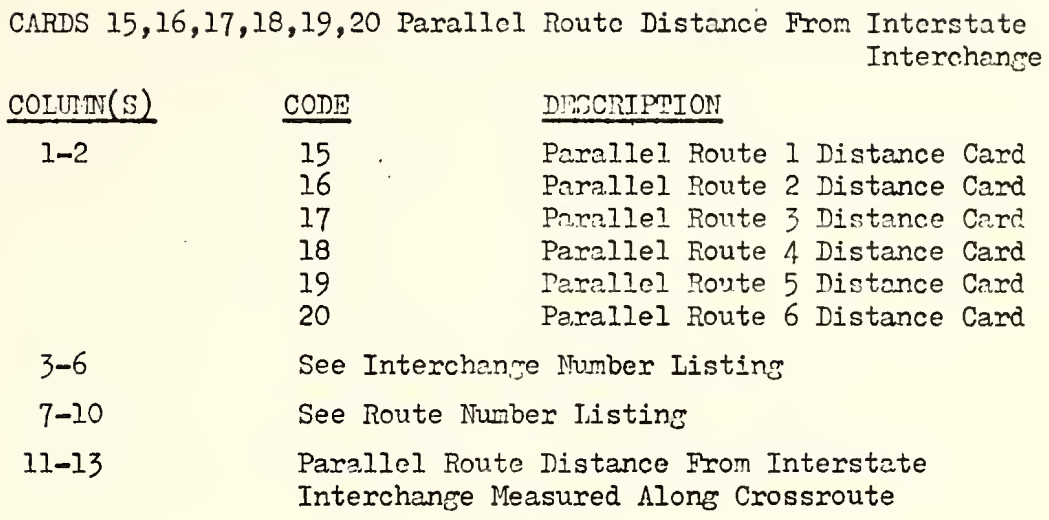


CARDS 23,27,31 Urban Center Populations

\begin{tabular}{|c|c|c|c|}
\hline COLUTAI(S) & CODE & DESCRT PTION & \\
\hline $1-2$ & $23,27,31$ & Urban Center Population & Card \\
\hline 3 & $\begin{array}{l}5 \\
6 \\
7\end{array}$ & $\begin{array}{l}1950 \\
1960 \\
1970\end{array}$ & \\
\hline $4-5$ & \multicolumn{3}{|c|}{ Interstate Route Number } \\
\hline 6 & $\begin{array}{l}1 \\
2 \\
3 \\
4\end{array}$ & $\begin{array}{l}\text { East of Indianapolis } \\
\text { North of Indianapolis } \\
\text { Vost of Indianapolis } \\
\text { South of Indianapolis }\end{array}$ & \\
\hline $7-12$ & \multicolumn{3}{|c|}{ Urban Center 1 Population } \\
\hline $13-18$ & \multicolumn{3}{|c|}{ Urban Center 2 Population } \\
\hline $19-24$ & \multicolumn{3}{|c|}{ Urban Center 3 Population } \\
\hline $25-30$ & \multicolumn{3}{|c|}{ Urban Center 1 Population } \\
\hline $31-36$ & \multicolumn{3}{|c|}{ Urban Center 5 Population } \\
\hline $37-42$ & \multicolumn{3}{|c|}{ Urban Center 6 Population } \\
\hline $43-4,8$ & \multicolumn{3}{|c|}{ Urban Center 7 Population } \\
\hline $49-54$ & \multicolumn{3}{|c|}{ Urban Center 8 Population } \\
\hline $55-60$ & \multicolumn{3}{|c|}{ Urban Center 9 Population } \\
\hline $61-66$ & \multicolumn{3}{|c|}{ Urban Center 10 Population } \\
\hline $67-72$ & \multicolumn{3}{|c|}{ Urban Center 11 Population } \\
\hline $73-78$ & \multicolumn{3}{|c|}{ Urban Center 12 Population } \\
\hline
\end{tabular}

See Urban Center Identification Table 
CARDS 24,28,32 Urban Center Populations

\begin{tabular}{|c|c|c|}
\hline COLUTAN(s) & $\underline{\mathrm{CODT}}$ & DESCRIPTION \\
\hline $1-2$ & $21,28,32$ & Urban Center Population Card \\
\hline 3 & $\begin{array}{l}5 \\
6 \\
7\end{array}$ & $\begin{array}{l}1950 \\
1960 \\
1970\end{array}$ \\
\hline $4-5$ & Interstate Rout & te Number \\
\hline 6 & $\begin{array}{l}1 \\
2 \\
3 \\
4\end{array}$ & $\begin{array}{l}\text { East of Indianapolis } \\
\text { North of Indianapolis } \\
\text { Vest of Indiananolis } \\
\text { South of Indianapolis }\end{array}$ \\
\hline $7-12$ & Urban Center 13 & 3 Population \\
\hline $13-18$ & Urban Center 14 & 4 Population \\
\hline $19-24$ & Urban Center 15 & 5 Population \\
\hline $25-30$ & Urban Center 16 & 6 Population \\
\hline $31-36$ & Urban Center 17 & 7 Population \\
\hline $37-42$ & Urban Center 18 & 8 Population \\
\hline $43-18$ & Urban Center 19 & 9 Population \\
\hline $49-54$ & Urban Center 20 & 0 Population \\
\hline $55-60$ & Urban Center 21 & 1 Population \\
\hline $61-66$ & Urban Center 22 & 2 Population \\
\hline $67-72$ & Urban Center 23 & 3 Population \\
\hline $73-78$ & Urban Center 24 & 4 Population \\
\hline
\end{tabular}

See Urban Center Identification Table 


\section{CARDS 25,29,33 Urban Center Populations}

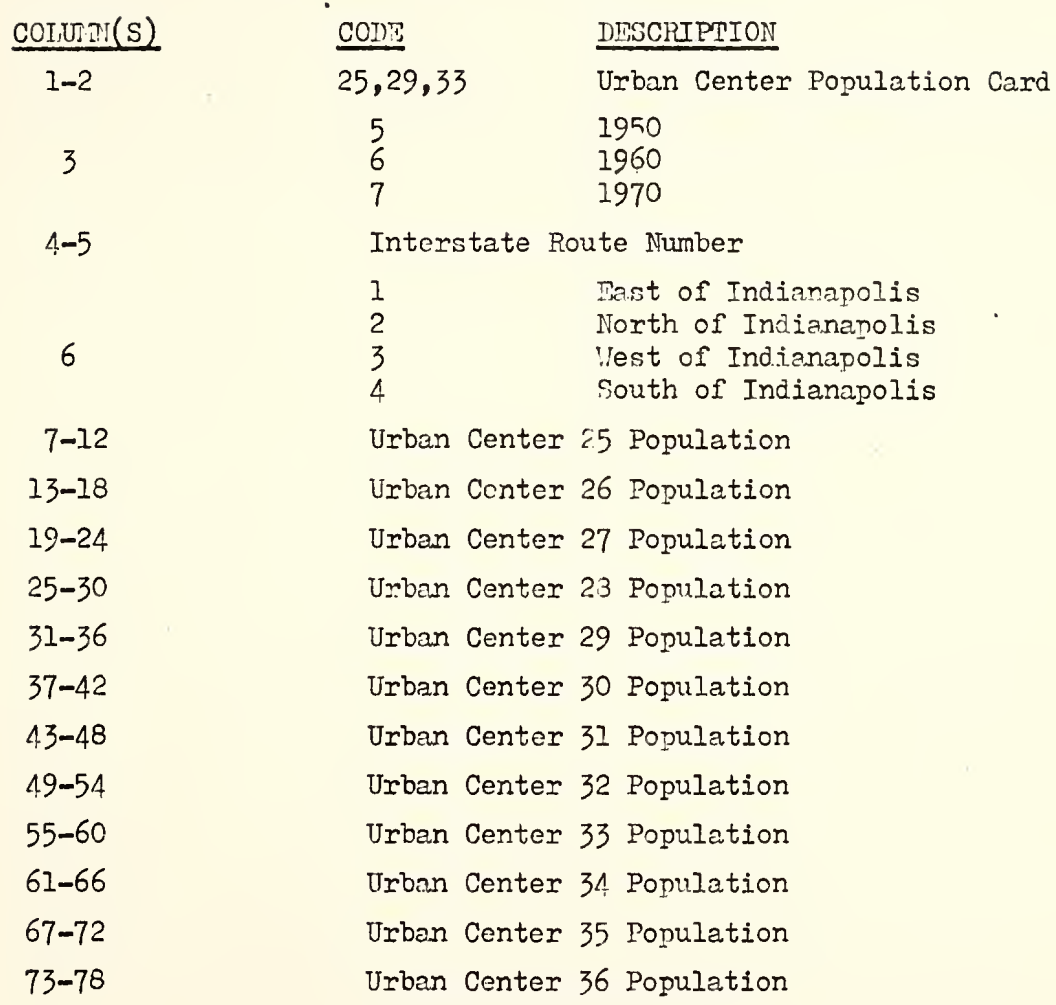

See Urban Center Identification Table 
CARDS 26,30,31 Urban Center Poptlations

\begin{tabular}{cll} 
COIUND(S) & CODE & DESCRIPTION \\
\hline $1-2$ & $26,30,34$ & Urban Center Population Card \\
3 & 5 & 1950 \\
& 6 & 1960 \\
$4-5$ & 7 & 1970 \\
6 & Interstote Route Number \\
& 2 & Nast of Tndianapolis \\
& 3 & North of Indianapolis \\
$7-12$ & 4 & South of Indianapolis \\
$13-18$ & Urban Center 37 Population \\
$19-24$ & Trban Center 38 Population \\
$25-30$ & Urban Center 39 Population \\
$31-36$ & Urban Center 10 Population \\
$37-12$ & Urban Center 41 Population \\
$43-48$ & Urban Center 42 Population \\
$49-54$ & Urban Center 43 Population \\
$55-60$ & Urban Center 44 Population \\
$61-66$ & Urban Center 45 Population \\
$67-72$ & Urban Center 45 Population \\
$73-78$ & Urban Center 17 Population \\
& Urban Conter 48 Population
\end{tabular}

Sce Urban Conter Identification Table 
CARD il Intcrchance Opening Data

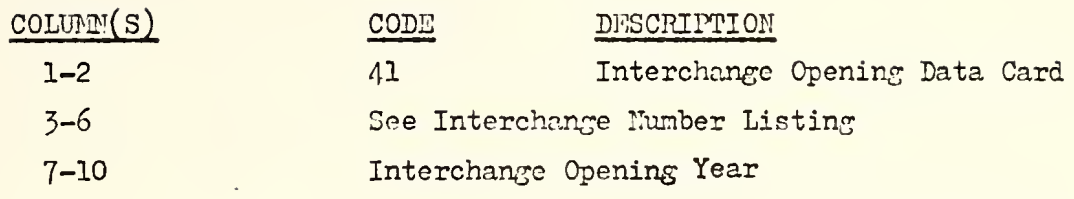


CARD 13 Interchange Rood User Development

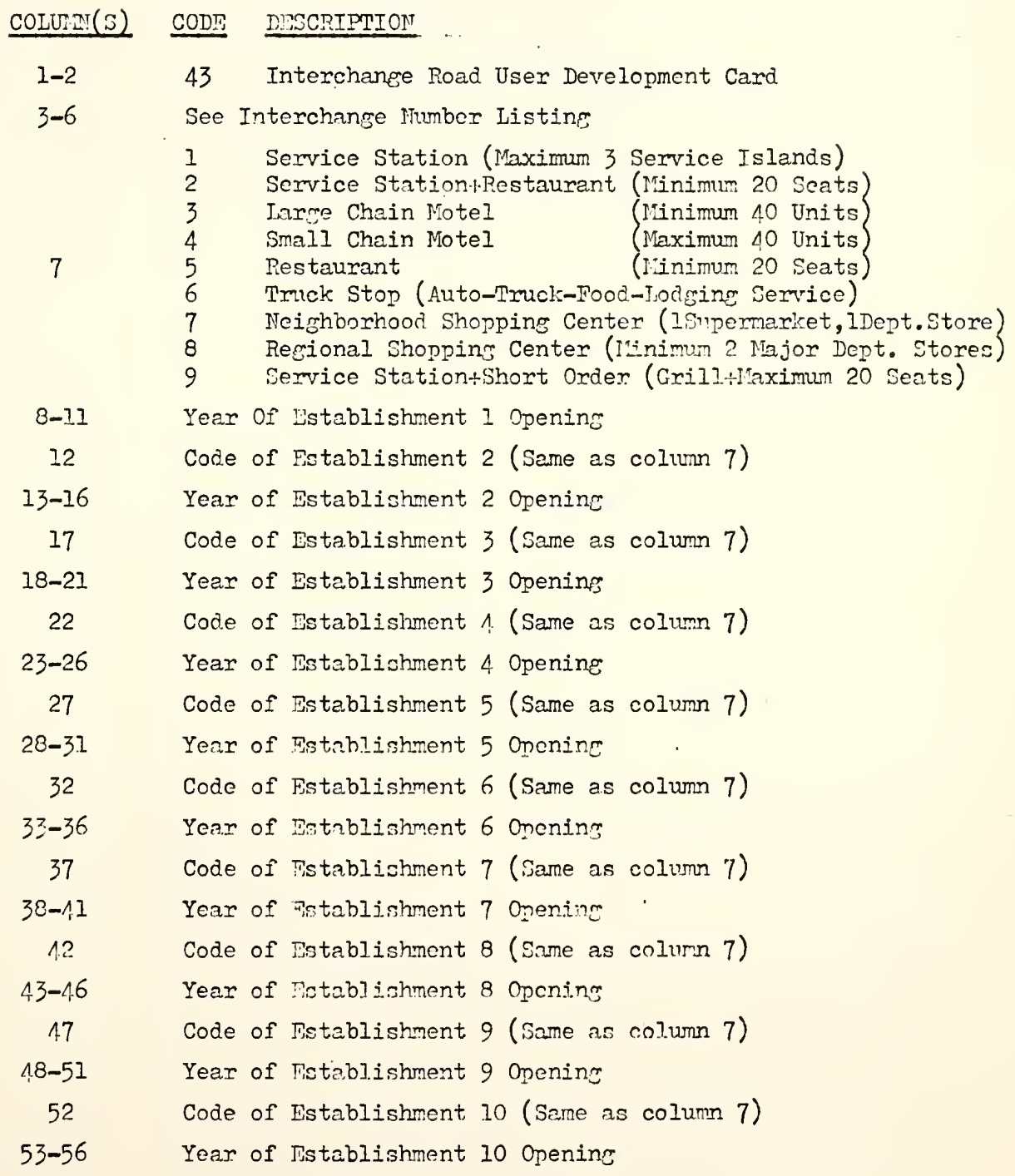




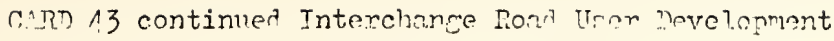

\begin{tabular}{|c|c|}
\hline$L T I T(S)$ & CONE, DTSCRIPnTON! \\
\hline 57 & Code of Fatablishment II (Same as column 7) \\
\hline $58-61$ & Year of Fstablishment 11 Openine \\
\hline 62 & Code of Istablizhment 12 (Sane as column 7) \\
\hline $63-66$ & Year of Dstablishment 12 Openins \\
\hline 67 & Code of Fistablishment 13 (Same as column 7) \\
\hline $68-71$ & Year of Establishment 13 Opening \\
\hline 72 & Code of Istabliahmont 14 (Same as column 7) \\
\hline $73-76$ & Year of Establishment 14 Opening \\
\hline
\end{tabular}


CARDS 51,52,53,54 Measured Distances From Urban - Centers To Interchanges

\begin{tabular}{|c|c|c|c|}
\hline olumar $(\mathrm{s})$ & $O D E$ & DESCRIPTION & \\
\hline $1-2$ & $\begin{array}{l}51 \\
52 \\
53 \\
54\end{array}$ & $\begin{array}{l}\text { Interstate } \\
\text { Two Lane Rural } \\
\text { Nulti-Iane Pural } \\
\text { Urban 4-Iane }\end{array}$ & $\begin{array}{l}\text { Highway Mileage Components } \\
\text { of Iinimum Travel Distance } \\
\text { Irom Interchange To Urban } \\
\text { Center Card }\end{array}$ \\
\hline $3-6$ & e Ir & nterchange Number & $r$ Iisting \\
\hline $7-10$ & $\begin{array}{l}\text { Appror } \\
\text { Urban }\end{array}$ & $\begin{array}{l}\text { priate Component } \\
\text { Center } 1\end{array}$ & From Inter \\
\hline $11-14$ & $\begin{array}{l}\text { Appror } \\
\text { Urban }\end{array}$ & $\begin{array}{l}\text { priate Component } \\
\text { Center } 2\end{array}$ & Distance From Interchanfe : \\
\hline $15-18$ & $\begin{array}{l}\text { Appror } \\
\text { Urban }\end{array}$ & $\begin{array}{l}\text { priate Component } \\
\text { Center } 3\end{array}$ & Distance From Interchange $\mathrm{T}$ \\
\hline $19-22$ & $\begin{array}{l}\text { Appror } \\
\text { Urban }\end{array}$ & $\begin{array}{l}\text { priate Component } \\
\text { Center } 4\end{array}$ & e From Interchange : \\
\hline $23-26$ & $\begin{array}{l}\text { Appror } \\
\text { Urban }\end{array}$ & $\begin{array}{l}\text { priate Component } \\
\text { Center } 5\end{array}$ & Distance From Interc \\
\hline $27-30$ & $\begin{array}{l}\text { Appror } \\
\text { Urban }\end{array}$ & $\begin{array}{l}\text { priate Component } \\
\text { Conter } 6\end{array}$ & Distance From Interchange \\
\hline $31-34$ & $\begin{array}{l}\text { Appror } \\
\text { Urban }\end{array}$ & $\begin{array}{l}\text { priate Component } \\
\text { Center } 7\end{array}$ & Distance From Interchange : \\
\hline $35-38$ & $\begin{array}{l}\text { Appror } \\
\text { Urban }\end{array}$ & $\begin{array}{l}\text { priate Component } \\
\text { Center } 8\end{array}$ & Distance From Interchange \\
\hline $39-42$ & $\begin{array}{l}\text { Appror } \\
\text { Urban }\end{array}$ & $\begin{array}{l}\text { priate Component } \\
\text { Center } 9\end{array}$ & Distance From Interchange \\
\hline $43-46$ & $\begin{array}{l}\text { Appror } \\
\text { Urban }\end{array}$ & $\begin{array}{l}\text { priate Component } \\
\text { Center } 10\end{array}$ & Distance From Interchang \\
\hline $47-50$ & $\begin{array}{l}\text { Appror } \\
\text { Urban }\end{array}$ & $\begin{array}{l}\text { priate Component } \\
\text { Center II }\end{array}$ & Distance Irom Interchange \\
\hline $51-54$ & $\begin{array}{l}\text { Appr } \\
\text { Urba }\end{array}$ & $\begin{array}{l}\text { priate Component } \\
\text { Center } 12\end{array}$ & Distance From Interchange \\
\hline
\end{tabular}


CARDS $61,62,63,64$ Measured Distances From Urban Centers To Interchanges

\begin{tabular}{|c|c|c|}
\hline COLUMN $(S)$ & CODE DESCRIPTION & \\
\hline $1-2$ & $\begin{array}{l}\text { Interstate } \\
\text { Two Iane Fural } \\
\text { Ifulti-Iane Rural } \\
\text { Urban 4-Iane }\end{array}$ & $\begin{array}{l}\text { Highway Uileage Components } \\
\text { of Minimum Travel Distance } \\
\text { From Interchange To Urban } \\
\text { Center Card }\end{array}$ \\
\hline $3-6$ & See Interchange Number & listing \\
\hline $7-10$ & $\begin{array}{l}\text { Appropriate Component } \\
\text { Urban Center } 13\end{array}$ & Distance From Interchange \\
\hline $11-14$ & $\begin{array}{l}\text { Appropriate Component } \\
\text { Urban Center } 14\end{array}$ & Distance From Interchange To \\
\hline $15-18$ & $\begin{array}{l}\text { Appropriate Component } \\
\text { Urban Center } 15\end{array}$ & Distance From Int \\
\hline $19-22$ & $\begin{array}{l}\text { Appropriate Component } \\
\text { Urban Center } 16\end{array}$ & Distance From Interchange To \\
\hline $23-26$ & $\begin{array}{l}\text { Appropriate Component } \\
\text { Urban Center } 17\end{array}$ & Distance From Interchange To \\
\hline $27-30$ & $\begin{array}{l}\text { Appropriate Component } \\
\text { Urban Center } 18\end{array}$ & Distance From Interchange To \\
\hline $31-34$ & $\begin{array}{l}\text { Appropriate Component } \\
\text { Urban Center } 19\end{array}$ & Distance From Interchange To \\
\hline $35-38$ & $\begin{array}{l}\text { Appropriate Component } \\
\text { Urban Center } 20\end{array}$ & Distance From Interchange To \\
\hline $39-42$ & $\begin{array}{l}\text { Appropriate Component } \\
\text { Urban Center } 21\end{array}$ & Distance From Interchange To \\
\hline $43-46$ & $\begin{array}{l}\text { Appropriate Component } \\
\text { Urban Center } 22\end{array}$ & Distance From Interchange To \\
\hline $47-50$ & $\begin{array}{l}\text { Appropriate Component } \\
\text { Urban Center } 23\end{array}$ & Distance From Interchange To \\
\hline $51-54$ & $\begin{array}{l}\text { Appropriate Component } \\
\text { Urban Center } 24\end{array}$ & ce From Interch \\
\hline
\end{tabular}


CARDS 71,72,73,74 Measured Distances From Urban Centers To Interchanges

\begin{tabular}{|c|c|c|c|}
\hline COLUMN $(s)$ & CODE & DFSCRIPTION & \\
\hline $1-2$ & $\begin{array}{l}71 \\
72 \\
73 \\
74\end{array}$ & $\begin{array}{l}\text { Interstate } \\
\text { Two Iane Rural } \\
\text { Multi-Iane Rural } \\
\text { Urban 4-Iane }\end{array}$ & $\begin{array}{l}\text { Highway Mileage Components } \\
\text { of Minimum Travel Distance } \\
\text { From Interchange To Urban } \\
\text { Center Card }\end{array}$ \\
\hline $3-6$ & Ṡee I & interchange Number & Listing \\
\hline $7-10$ & $\begin{array}{l}\text { Appro } \\
\text { Urban }\end{array}$ & $\begin{array}{l}\text { priate Component } \\
\text { Center } 25\end{array}$ & ce From Interchange \\
\hline $11-14$ & $\begin{array}{l}\text { Appro } \\
\text { Urban }\end{array}$ & $\begin{array}{l}\text { priate Component } \\
\text { Center } 26\end{array}$ & ice From Inte \\
\hline $15-18$ & $\begin{array}{l}\text { Appro } \\
\text { Urban }\end{array}$ & $\begin{array}{l}\text { priate Component } \\
\text { Center } 27\end{array}$ & Distance From Interchange \\
\hline $19-22$ & $\begin{array}{l}\text { Appro } \\
\text { Urbar }\end{array}$ & $\begin{array}{l}\text { priate Component } \\
\text { Center } 28\end{array}$ & Distance From Interchange \\
\hline $23-26$ & $\begin{array}{l}\text { Appro } \\
\text { Urban }\end{array}$ & $\begin{array}{l}\text { priate Component } \\
\text { Center } 29\end{array}$ & Distance From Interchange \\
\hline $27-30$ & $\begin{array}{l}\text { Appro } \\
\text { Urban }\end{array}$ & $\begin{array}{l}\text { priate Component } \\
\text { Center } 30\end{array}$ & Distance From Interchang \\
\hline $3.2-34$ & $\begin{array}{l}\text { Appro } \\
\text { Urbar }\end{array}$ & $\begin{array}{l}\text { priate Component } \\
\text { Center } 31\end{array}$ & Distance From Interchange \\
\hline $35-38$ & $\begin{array}{l}\text { Appro } \\
\text { Urbar }\end{array}$ & $\begin{array}{l}\text { priate Component } \\
\text { Center } 32\end{array}$ & Distance From Interchange \\
\hline $39-42$ & $\begin{array}{l}\text { Appro } \\
\text { Urban }\end{array}$ & $\begin{array}{l}\text { priate Component } \\
\text { Center } 33\end{array}$ & Distance From Inter \\
\hline $43-46$ & $\begin{array}{l}\text { Appro } \\
\text { Urban }\end{array}$ & $\begin{array}{l}\text { priate Component } \\
\text { Center } 34\end{array}$ & Distance From Interchange \\
\hline $47-50$ & $\begin{array}{l}\text { Appro } \\
\text { Urban }\end{array}$ & $\begin{array}{l}\text { priate Component } \\
\text { Center } 35\end{array}$ & Distance From Interchang \\
\hline $51-54$ & Appro & priate Component & Distance From Interchange \\
\hline
\end{tabular}


CARDS $81,82,83,84$ Measured Distances From Urban Centers To Interchanges

COLUMNS(S) CODF DESCRIPTION

1-2 $\begin{array}{lll}81 & \text { Interstate } & \text { Highway Mileage Components } \\ 82 & \text { Two Iane Rural of Minimum Travel Distance } \\ 83 & \text { Multi-Iane Rural From Interchange To Urban } \\ & 84 & \text { Urban 4-Iane Center Card }\end{array}$

See Interchange Number Listing

$7-10$

Appropriate Component Distance From Interchance. To Urban Center 37

$11-14$

Appropriate Component Distance From Interchange To Urban Center 38

$15-18$

Appropriate Component Distance From Interchange To Urban Center 39

$19-22$

Appropriate Component Distance From Interchange To Urban Center 40

$23-26$

Appropriate Component Distance From Interchange To Urban Center 41

$27-30$

Appropriate Component Distance From Interchange To Urban Center 42

$31-34$

Appropriate Component Distance From Interchange To Urban Center 43

$35-38$

Appropriate Component Distance From Interchange To Urban Center 44

$39-42$

Appropriate Component Distance From Interchange To Urbar Center 45

43-46 Appropriate Component Distance From Interchange To Urban Center 46

$47-50$

Appropriate Component Distance From Interchange To Urban Center 47

$51-54$

Appropriate Component Distance From Interchange To Urban Center 48 
APPENDIX D

ADT EXPANSION FACTORS 


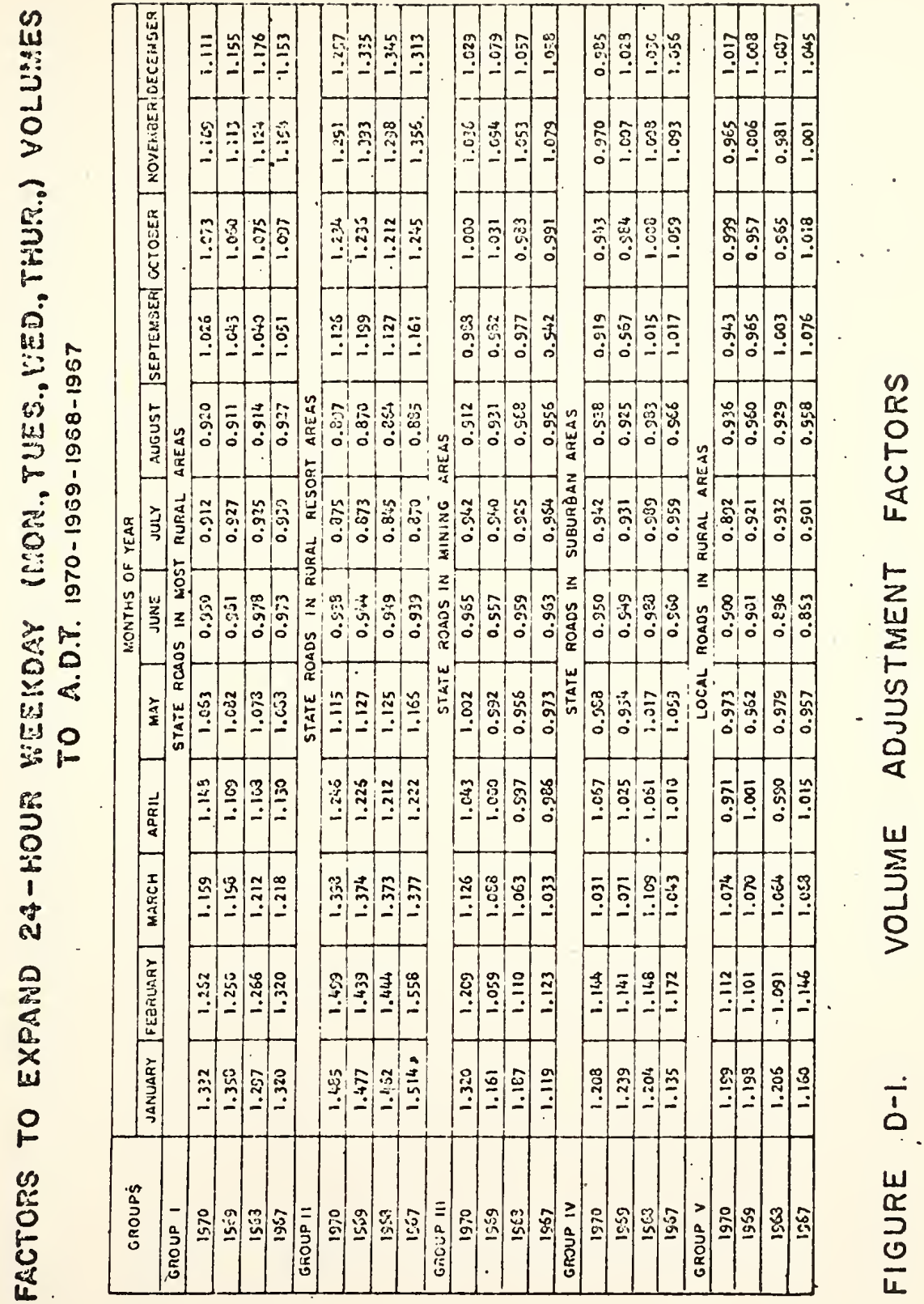




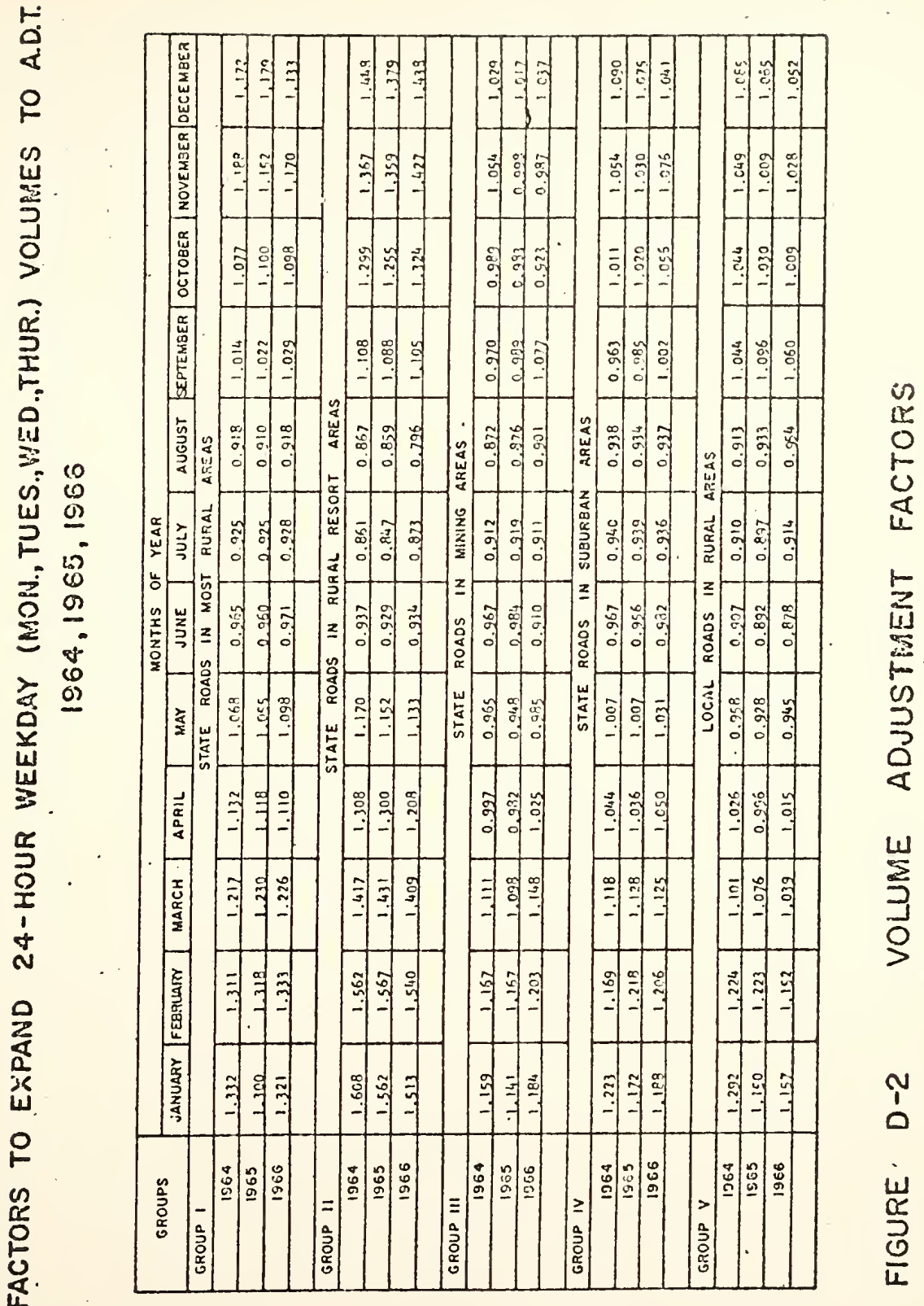




\section{APPENDIX E}

STATISTICAL

PLOTS FOR THE IAND USE

DEVELOPIANT MODEL 


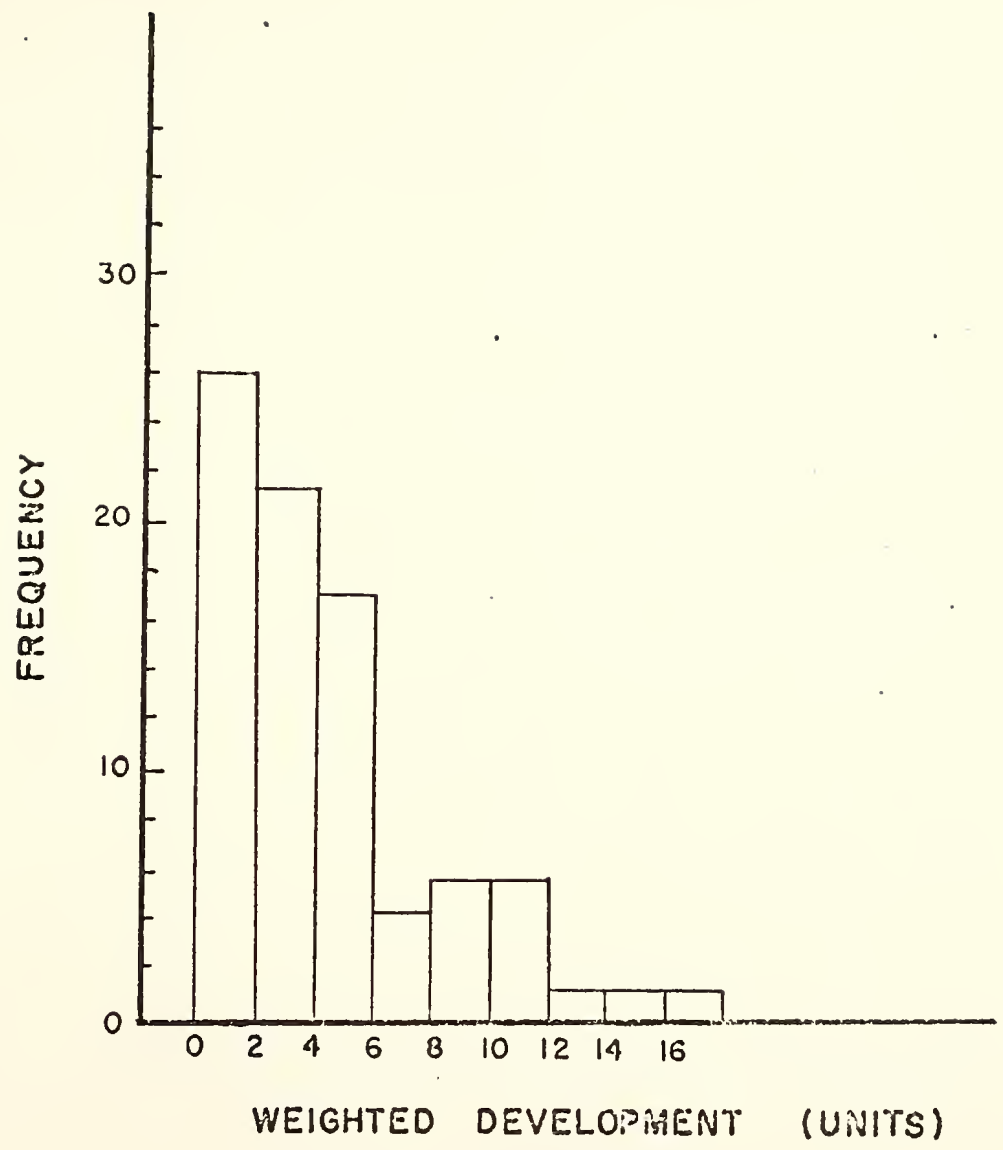

FIGURE E-I. HISTOGRAM OF VEIGHTED DEVELOPRENT 82 CASES 


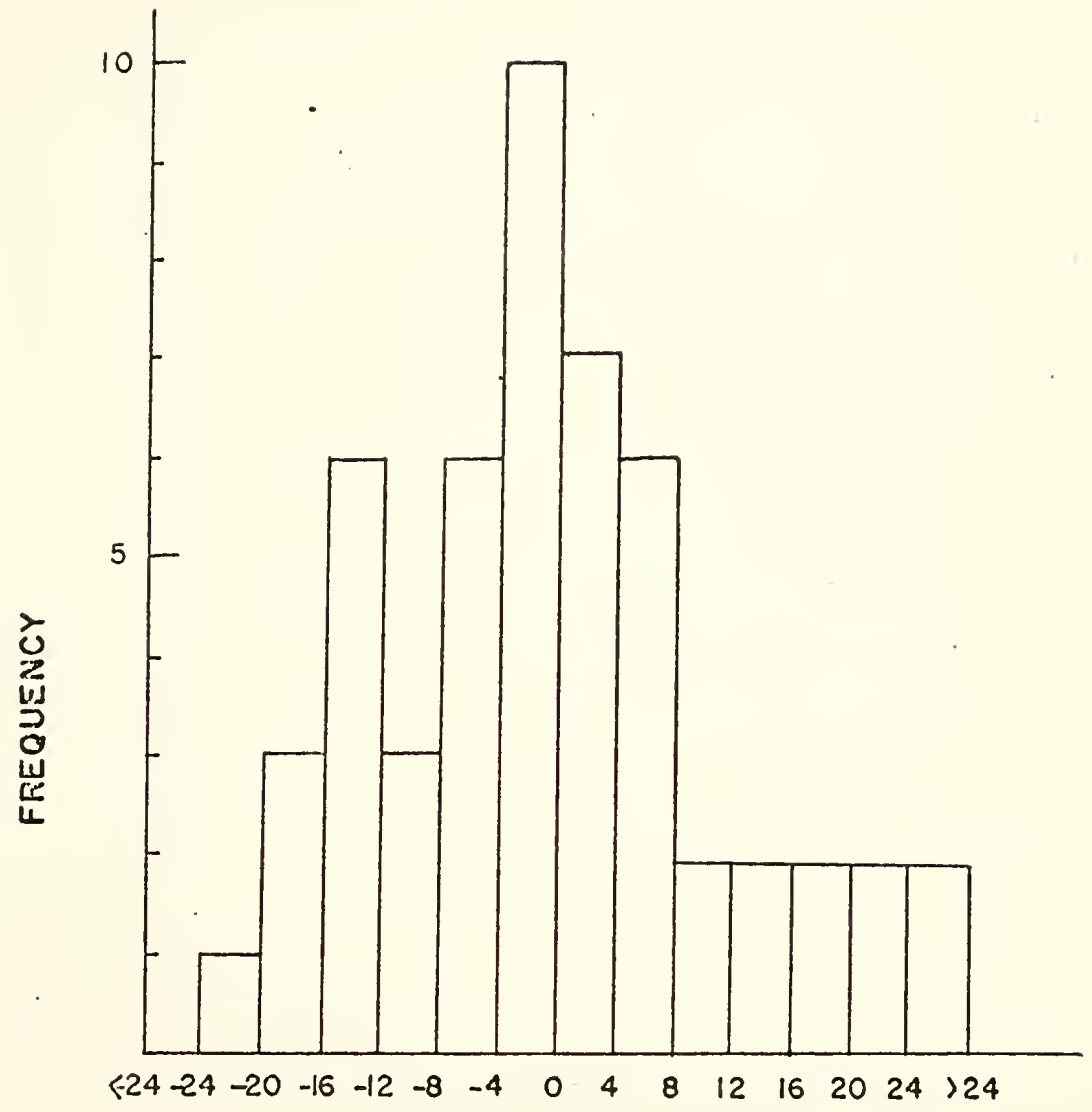

RESIOUAL OF VEIGHTED DEVELOPMENT (UNITS)

FIGURE E-2. RESIDUAL HISTOGRAM FOR FINAL WEIGHTED MODEL WITH 52 CASES 


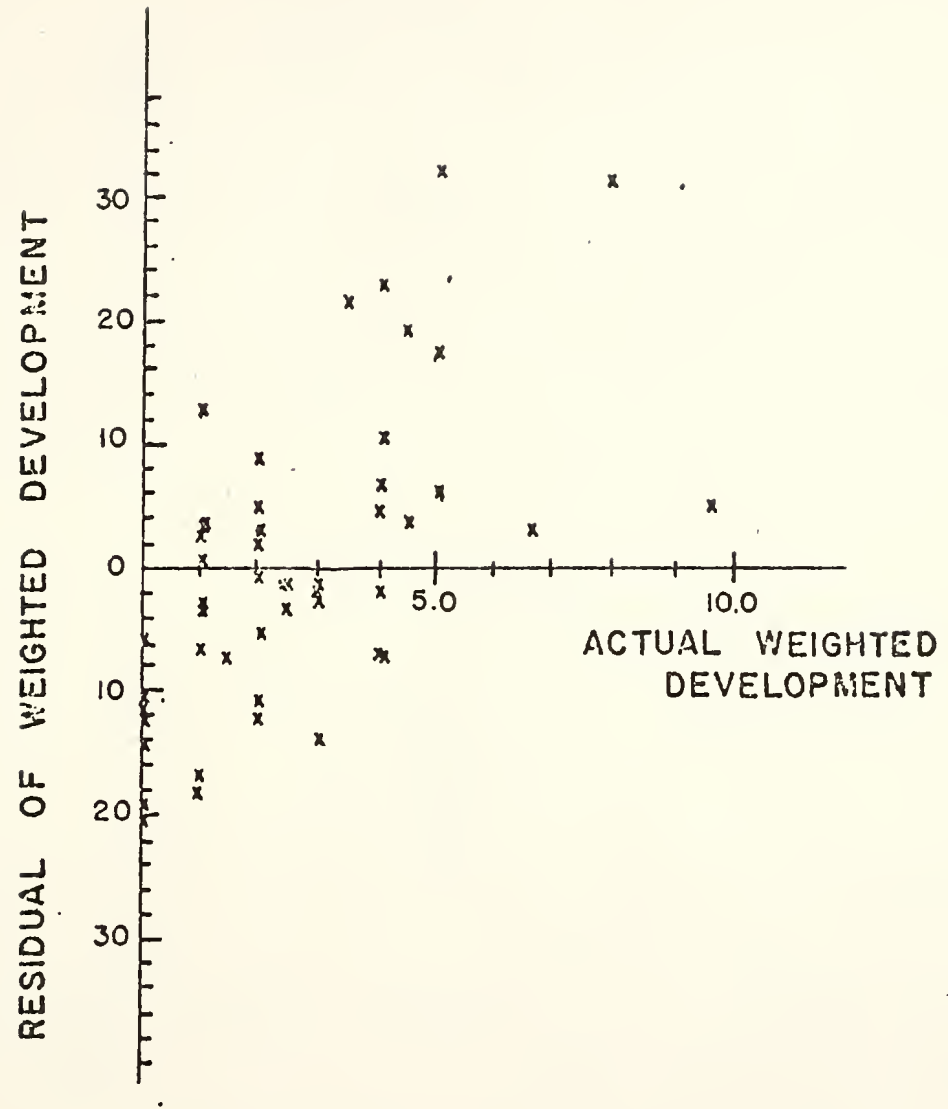

FIGURE E-3. RESIDUALS VERSUS $\hat{y}_{i}$ For 52 CASES 

